Universidade de São Paulo

Escola de Comunicações e Artes

Programa de Pós-graduação em Artes Visuais

Processos de Criação em Artes Visuais

\title{
Corpo Híbrido
}

\section{Viviane Vallades da Silva}

Orientador:

Prof. Dr. Hugo Fernando Salinas Fortes J únior

Tese apresentada ao Programa de Pós - Graduação em Artes Visuais, área de concentração Poéticas Visuais, linha de pesquisa Processos de Criação em Artes Visuais, da Escola de Comunicações e Artes da Universidade de São Paulo, como exigência parcial para obtenção do Título de Doutora em Artes Visuais, sob a orientação do Prof. Dr. Hugo Fernando Salinas Fortes Júnior 
Autorizo a reprodução e divulgação total ou parcial deste trabalho, por qualquer meio convencional ou eletrônico, para fins de estudo e pesquisa, desde que citada a fonte.

Catalogação na Publicação

Serviço de Biblioteca e Documentação

Escola de Comunicações e Artes da Universidade de São Paulo

Dados inseridos pelo(a) autor(a)

Silva, Viviane Vallades da

Corpo Híbrido / Viviane Vallades da Silva ; orientador, Hugo Fortes. -- São Paulo, 2019.

115 p.: il. + DVD.

Tese (Doutorado) - Programa de Pós-Graduação em Artes

Visuais - Escola de Comunicações e Artes / Universidade de São Paulo.

Bibliografia

Versão original

1. corpo 2. relações sociais 3. mutações da sensibilidade

4. efemeridade 5. humano-máquina I. Fortes, Hugo II. Título.

CDD 21.ed. -700

Elaborado por Sarah Lorenzon Ferreira - CRB-8/6888 
BANCA EXAMI NADORA

$\operatorname{Prof}(a) . \operatorname{Dr}(a)$.

$\operatorname{Prof}(a) . \operatorname{Dr}(a)$

$\operatorname{Prof}(a) . \operatorname{Dr}(a)$.

$\operatorname{Prof}(a) . \operatorname{Dr}(a)$.

$\operatorname{Prof}(a) . \operatorname{Dr}(a)$. 


\section{Agradecimentos}

Ao meu orientador Prof. Dr. Hugo Fortes, pelo processo de orientação e acompanhamento.

Agradeço aos membros participantes da banca de qualificação Branca de Oliveira e Neide Jallageas pela contribuição no pensar e pelos apontamentos para novas rotas.

Aos professores Prof. Dr. Felisberto Sabino da Costa e Prof. Dr. Marcelo Denny de Toledo Leite e todos os professores e amigos.

Ao crítico e pesquisador Oscar D'Ambrosio pelo texto e pelos comentários e sugestões que teceu em relação aos meus trabalhos.

Aos meus pais Adilson Vallades e Mercedes Espirito da Silva que acompanha e participa dos registros da maioria das ações e trabalhos que realizo.

Às minhas irmãs Shirlei Vallades e Regina Vallades, que também participa da produção e registro de muitos dos trabalhos que faço.

À minha sobrinha Marina Vallades Guimarães, que me possibitou entender mais sobre crescimento, vida e me emprestou alguns de seus brinquedos que também fazem parte de alguns dos trabalhos apresentados neste estudo.

Kadu Rossi que contribuiu para o desenvolvimento do trabalho Transporto Sentimentos registrando toda a ação.

Ao MIS (Museu da Imagem e do Som) pelo apoio na Residência Artística do LABMIS (Laboratório de Novas Mídias do Museu da Imagem e do Som) com o trabalho Transporto Sentimentos.

À Maria Stella Valli pela revisão dos textos. 


\section{Sumário}

Resumo / Abstract 9

I ntrodução 11

Capítulo 1: Corpo em suspensão 17

Capítulo 2: Reflexões do corpo 29

2.1 Sem Título, 2015. (vídeo) 29

2.2 Autorretrato com chave de fenda 38

Capítulo 3 : Peles, cascas, máscaras e metamorfoses

3.1 "Sem Título" (Fotografia) 45

3.2 "Sem Título" (vídeo e videoinstalação) 47

3.3 Sem Título (ação para a câmera fotográfica. Série de 06 fotografias)

3.4 "Sem Título" Versão 1 e versão 2 (vídeos) 51

3.5 "Sem Título (03 fotografias) 55

\section{Capítulo 4: 0 corpo em palavras e falas}

4.1. Sem Título (Vídeo, 2015) 60

4.2 Transporto sentimentos 66

4.3 Sem Título, Work in Progress (2015 - ...) 76

4.3.1 Sem Título, realizado na rede social Facebook

4.3.2 "Sem Título" no formato de painel de led 94

4.3.3 "Sem Título" em instalação audiovisual 96

\section{Considerações 99}

Ficções futuras 102

Ficções futuras 104

Referências 107

Apêndice 115 


\section{Resumo}

Esta pesquisa teve como objetivo a realização de experimentos poéticos em artes visuais, que também foram o seu objeto de estudo. Os experimentos pretenderam explorar imagens de meu corpo em seus estados transitórios, realizando ações e modificações, por meio de peles artificiais e máscaras e acrescentando dispositivos ao corpo, produzindo sensações visuais, táteis, auditivas, espaciais e temporais que buscam gerar reflexões sobre os corpos dos seres em geral. Através das ações que meu corpo realiza ou, em alguns outros trabalhos, por meio de palavras que remetem ao corpo e a seus comportamentos, pretendi produzir sensações e ficções que discutem questões ligadas à existência cotidiana como: relações sociais, efemeridade, mutações da sensibilidade, subjetividade, relação humano-máquina e mecanização dos sentimentos.

Palavras-chave:

corpo, relações sociais, mutações da sensibilidade, efemeridade, humano-máquina.

\section{Abstract}

This research aimed to carry out poetic experiments, which were also its object of study. The experiments attempted to explore images of my body in its transient states, performing actions and modifications, using artificial skins and masks, adding devices to the body, producing visual, tactile, auditory, spatial and temporal sensations which seek to generate reflections on the bodies of beings in general. Through the actions that my body performs or in some other works, through words that refer to the body and its behaviors, I intend to produce sensations and fictions that discuss issues related to daily existence such as: social relations, ephemerality, sensitivity mutations, subjectivity, humanmachine relationship and mechanization of feelings.

Keywords: body, social relationships, sensitivity mutations, ephemerality, human-machine. 
Passei a repolir aquele corpo 


\section{I ntrodução}

Esta tese tem como objeto de estudo os experimentos poéticos que realizei durante 0 doutorado. Os experimentos pretenderam explorar imagens de meu corpo em seus estados transitórios, ações e modificações, produzindo sensações visuais, táteis, auditivas, espaciais e temporais que buscam gerar reflexões sobre os corpos dos seres em geral. Através das ações que meu corpo realiza ou, em alguns outros trabalhos, por meio de palavras que remetem ao corpo e a seus comportamentos pretendi produzir sensações e ficções que discutem questões ligadas à existência cotidiana como: relações sociais, efemeridade, mutações da sensibilidade, subjetividade, relação humano-máquina e mecanização dos sentimentos. Os trabalhos englobam desde rituais em que o corpo passa por dissoluções, em uma longa duração de tempo, até a apresentação ou menção de corpos e seus comportamentos de forma "mais mecanizada". São corpos de passagem e apresentam diferentes estados psicológicos e estados provisórios do ser.

Desde 1998 tive interesse pelo corpo. Se a princípio estava interessada em representá-lo utilizando tanto o meu corpo como observando e tomando contato com o corpo de outros seres, passei posteriormente, por volta de 2011, a trabalhar meu corpo em ações para a câmera principalmente. Porém, na passagem de procedimentos de desenho, pintura e colagem para o uso de meu corpo ocorreram resquícios dos procedimentos anteriores. 
Trabalhava muito com "peles", texturas, cascas de materiais em decomposição e sobreposição de corpos nos desenhos que fazia, que passaram a habitar temporariamente meu corpo nas ações que realizo e que serão apresentadas nesta tese.

Utilizo meu corpo na maioria dos trabalhos, porém este corpo trata dos corpos em geral, não de meu corpo em particular. Mesmo em obras que miram o autorretrato, procuro refletir o corpo de forma mais ampla, como o corpo em sua efemeridade, seus embates diante de convenções, normas e dúvidas.

A palavra corpo agrega muitos sentidos:

Lugar da biologia, das expressões psicológicas, dos receios e fantasmas culturais, o corpo é uma palavra polissêmica, uma realidade multifacetada e, sobretudo, um objeto histórico. [. ..] Resultado provisório das convergências entre técnica e sociedade, sentimentos e objetos, ele pertence menos à natureza do que à história. (SANT'ANNA, 1995, p.12)

É sobre essa polissemia de sentidos atribuídos à palavra corpo que os meus trabalhos pretendem refletir, pois não tratam apenas de aparência física mas também do que nos afeta e o que também nos é agregado (agregado aqui no sentido de que acaba por ser inserido no corpo, como modelos culturais, padrões, modos de sentir etc.) no decorrer da vida.

"Antes de qualquer coisa, a existência é corporal" (LE BRETON, 2007, p. 7). É com base nessa existência corporal que proponho criar sentidos, sensações e estranhamentos para reflexões sobre o corpo em um determinado espaço social e cultural.

Estamos num período de mudanças rápidas nas quais novos valores vão se instaurando, substituindo ou coexistindo com outros. Palavras como apatia, individualismo, consumismo, liquidez e indivíduo desestabilizado, dentre outras, são recorrentes e junto delas muitos paradoxos se apresentam. Estas palavras simplificam ou reduzem o momento atual, mas funcionam para nos fazer tentar compreender o momento histórico e modos de viver. Há inúmeras possibilidades em todos os níveis, de trabalho, sentimentais, econômicos etc., que hoje nos são oferecidas e ao mesmo tempo essa variedade gera angústia devido à tomada de decisões.

[...] todos os gostos, todos os comportamentos podem coabitar sem se excluírem [...] tanto o novo como o antigo, a vida simples e ecológica e a vida hipersofisticada, num tempo desvitalizado sem referências estáveis, sem coordenadas principais. (LIPOVETSKY, 1983, p.39)

A tecnologia com base na informação e na ciência transformou nosso modo de pensar, produzir, sentir etc. O ter passa a ser mais importante do que o ser.

Muito se fala do corpo e das modificações atuais para se alcançar beleza, longevidade, saúde etc. A cultura dita normas em relação ao corpo, às quais os indivíduos vão tentar se conformar. Os corpos são disciplinados para tornarem-se dóceis e submissos (FOUCAULT, 1987); dessa forma, se ajustam para um dia de trabalho, 
com rigor do horário, das posturas, do modo de se comportar para maximizar sua eficácia. Atualmente são apresentadas inúmeras possibilidades para o corpo e suas mudanças, tanto pela parte física como pelos modos de sentir, por meio de remédios, psicotrópicos etc.

Os trabalhos que apresento pretendem entrar nesse ambiente (que é bem mais amplo e paradoxal do que a simplificação acima), porém, pelo viés da sensação, da singularidade e da ficção nos campos de ordem mais psicológica, emocional, do sentir as relações sociais, emocionais, crises existenciais, angústias diante dessas mudanças e possibilidades atuais.

O trabalho com o corpo, por este se tratar de um objeto histórico, social e cultural, juntamente com suas singularidades, requer reflexão e inclui a intuição a partir do próprio processo de viver afetos e encontros. o processo criativo foi intuitivo e a aproximação que fiz está mais próxima da ficção e da cartografia sentimental ${ }^{1}$.

1 Suely Rolink em " Cartografia Sentimental: Transformações contemporâneas do desejo" (1989) comenta sobre o que ela chama de cartografia sentimental, métodos dos cartógrafos, suas referências e como se inserem no campo de pesquisa. Utilizo esse termo nesta tese como uma apropriação do utilizado pela autora, que também o retira de Deleuze e Guatari. Alguns apontamentos breves que utilizei e que estão descritos por Rolnik em seu texto: O cartógrafo é um antropófago, pois vive de apropriações, de devorar elementos para compor suas cartografias. Aponta também que ele não prevê o resultado de antemão. É em seu percurso que suas "metas" vão surgindo mais especificamente. O cartógrafo percebe, pela sensibilidade, mundos e configurações territoriais da existência. Também são utilizadas diversas referências, materiais de várias procedências (filmes, livros, música etc.). O que o cartógrafo quer é "participar, embarcar na constuição de territórios existenciais, constituição de realidade". ( ROLNIK, 1989,p. 67- 68) Como já
Todos os experimentos que realizei partiram de um "projétil" como aponta Sandra Rey em "Da prática à teoria: três instâncias metodológicas sobre a pesquisa em Poéticas Visuais" (1996). Um projétil é diferente de um projeto, pois neste sabemos aonde queremos chegar; sabe-se de antemão um possível resultado. “Um projétil é algo que é lançado como uma mira. Mas o caminho exato que irá percorrer nunca sabemos" (REY, 1996, p. 84). A princípio tinha como projétil trabalhar com meu corpo em ações e também por palavras para tratar de questões cotidianas que me afetavam. Este caminho foi sendo desenvolvido, mas os trabalhos, seu formato, o uso de vários meios e a ação em âmbitos fora do espaço tradicional das artes, como redes sociais, na rua, etc., foram aparecendo no decorrer do desenvolvimento dos próprios trabalhos. Embora a parte teórica tenha sido feita concomitantemente à sua produção, foi mais intensamente após a realização desses trabalhos que foquei a escrita e as leituras em diferentes campos, desde a literatura, filosofia, antropologia, sociologia até a cinematografia para pensar minha prática e encontrar ressonâncias e dissonâncias com o que estava pensando.

Embora tenha me utilizado desses textos e leituras, realizei uma pesquisa autônoma em artes e, como

comentado nesta introdução, fui pela sensibilidade tateando nossos sentimentos, possibilidades e reflexões sobre o corpo e suas relações, criando corpo ou corpos de trabalhos que apresentam cartografias ficcionais sobre instabilidades, modificações da paisagem em que nos encontramos. 
lembra Giorgio Agamben²:

[...] a literatura e o pensamento também fazem experimentos, tal como a ciência. Mas, enquanto a ciência visa provar a verdade ou falsidade de uma hipótese, a literatura e o pensamento têm outro objetivo. São experimentos sem verdade. (AGAMBEN apud PELBART, 2003, p.42)

São esses experimentos sem verdade que se revelarão no desenvolvimento desta tese. Muitos dos trabalhos que apresento abordam sentimentos, dúvidas e comportamentos dos corpos, sem querer aproximação com nenhum tipo de verdade. São apenas reflexões e principalmente fiç̧ões. Discorro em cada capítulo sobre o processo prático, sobre a produção, como os trabalhos foram ganhando corpo ou corpos. Também faço alguns apontamentos para a construção de sentidos e o que possivelmente me guiou a seguir tais caminhos, sem a intenção de fechar outros sentidos e leituras para os trabalhos.

Um procedimento recorrente em minha produção é ter versões dos trabalhos. Assim, um mesmo trabalho pode apresentar diferentes formas de apresentação, sendo exibido em diferentes suportes e meios, porém mantendo os aspectos conceituais de sua criação. Acredito que a temática da mudança, da mutação de sensibilidades, do devir da existência é o que faz esse procedimento ser recorrente em minha poética.
A tese foi dividida em capítulos em que agrupei trabalhos pelos elementos ou pela materialidade utilizada nas obras. Essa constatação ficou mais consciente para mim após conversas e um texto ${ }^{3}$ escrito pelo crítico e pesquisador Oscar D'ambrosio que apontou o fato de ser recorrente em meu trabalho o uso de alguns materiais e sugerir ligações entre eles. Assim, optei por dividir a tese por materiais de forma a unir os trabalhos, as ficções e cartografias escritas em cada capítulo.

Os elementos foram: espelhos, peles, máscaras, cascas, gelo, palavras e falas. Como cada um desses elementos e materialidades sempre estava relacionado com meu corpo, a cada capítulo ampliei as materialidades e essa relação poeticamente, ficando os capítulos com a seguinte configuração:

Capítulo 1: "Corpo em suspensão". Neste capítulo apresento uma série em que meu corpo é deformado, se dissolve no decorrer do tempo pela projeção em gelo. A efemeridade e o autorretrato são questões que giram em torno dessa relação.

Capítulo 2: "Reflexões do corpo". Neste capítulo abordo obras que fiz utilizando espelhos e reflexos do corpo. Nelas abordo questões sobre o autorretrato, o eu e o nós em seus embates com o espelho.

3 o texto encontra-se disponível em: http://oscardambrosio.com.br/textos/560/viviane-vallades 
Capítulo 3: "Peles, cascas, máscaras e metamorfoses". Neste capítulo abordo modificações corporais principalmente relacionadas à pele e alguns conceitos sobre ela. Relações sociais, máscaras e devires existenciais são os temas tratados.

Capítulo 4: "O corpo em palavras e falas". Neste capítulo abordo obras em que palavras e falas ficam em evidência e refletem sobre sentimentos, possibilidades do corpo e ficções existenciais. 


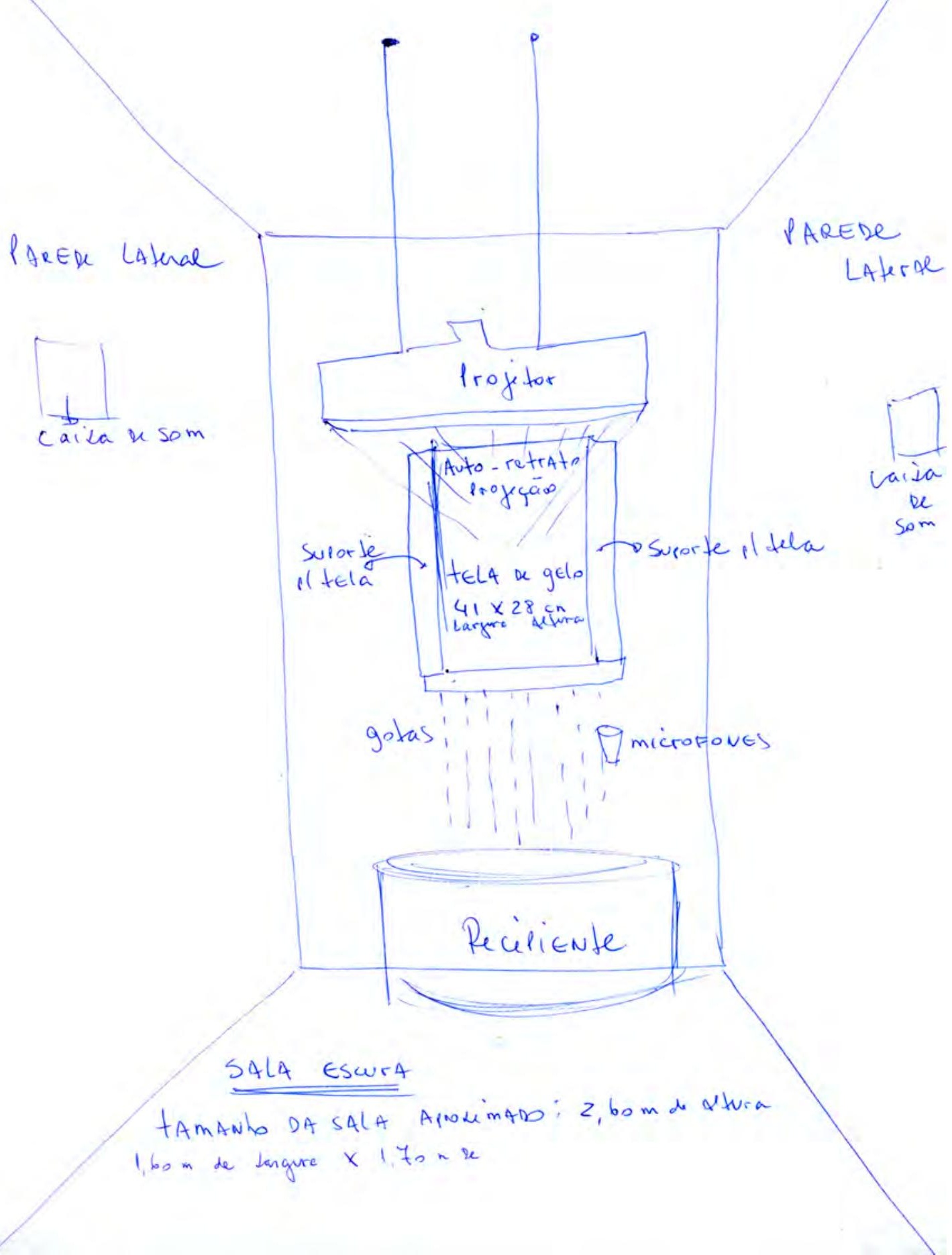




\section{Capítulo 1:}

\section{Corpo em suspensão}

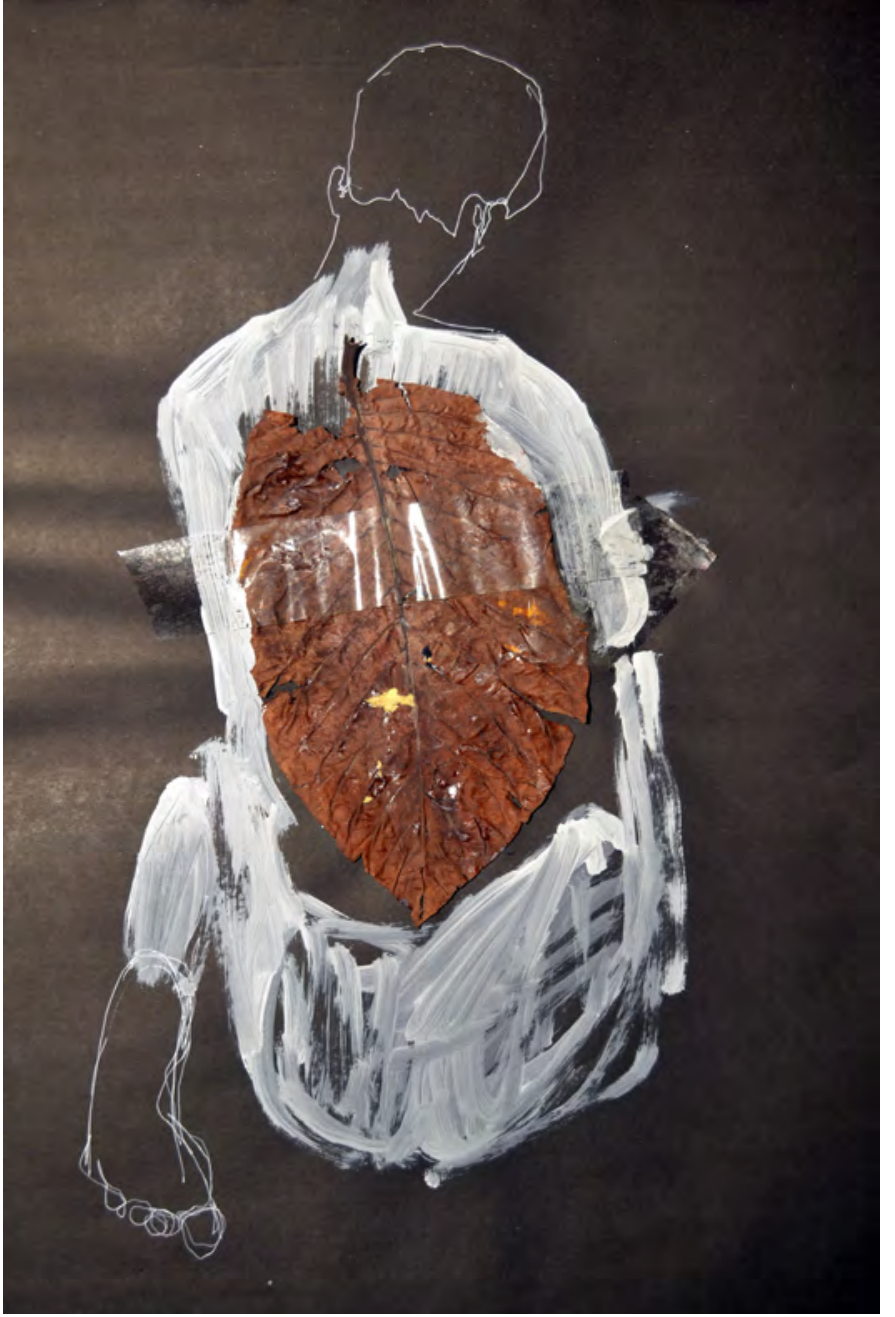

Desde 1996, bem antes de realizar ações performáticas como as que apresento nesta tese, constantemente realizava retratos e autorretratos, figura humana em desenho, pintura e colagem.

Nesses trabalhos meus interesses eram o corpo, estar diante de um outro ser e realizar a ação de desenhar ao 
vivo. Quase sempre as figuras apresentavam (e ainda apresentam - continuo realizando esse tipo de trabalho) manchas, borrões, com variedades de texturas nas "peles" retratadas, sobreposição de papéis e desenhos em camadas. Apresento aqui um pouco desse histórico, pois vejo uma continuidade de procedimentos que fazia nesses desenhos, principalmente no que se refere às texturas e sobreposições com os trabalhos aqui apresentados, assim como o interesse no corpo humano e em pensar o autorretrato principalmente em relação a essa série específica.

Além dos desenhos, por volta de 2006, fazia animações com recortes e desenhos e as projetava nas paredes de casa, em estantes, em objetos e me interessava muito em observar como a projeção era modificada em cada superfície.

A partir de 2011 passei a desenvolver ações para a câmera e senti necessidade de apresentar as imagens que captava sobre superfícies diferenciadas de projeção. Desta maneira, consegui potencializar significados, gerar relações espaciais e metafóricas que me interessavam.

Logo após ter sentido a necessidade de usar meu corpo, surgiu a vontade de fazer uma série de autorretratos no decorrer da vida que mudassem de forma no decorrer do tempo. Estava pensando em efemeridade, instabilidade, processos de devir e "deformação" da memória sobre a lembrança do que fomos. Esse pensamento ficou rondando minha mente por um tempo. Numa festa de casamento de um amigo em 2011 estava observando a iluminação quando vi a luz incidir em uma fumaça, dessas comuns em festas. Pensei em projetar o autorretrato em fumaça, porém achei que ainda assim não deformaria tanto a imagem por não ter uma espessura adequada para que isso ocorresse.

Um dia abri minha geladeira para pegar gelo e essa superfície me chamou muito a atenção e ia ao encontro de minha vontade de materializar autorretratos projetados que variassem de forma no decorrer do tempo. O gelo geraria durações diferentes a cada apresentação e poderia se constituir de uma série de autorretratos efêmeros, instáveis e ritualísticos. A ideia de trabalhar com uma série durante a vida também estava dentro dessa busca.

Passei a fazer vários experimentos com o gelo, colocando apenas água congelada em fôrmas de diferentes formatos, depois água com tintas de várias cores e por fim escolhi apresentar o autorretrato projetado em água congelada, tinta branca e em formato retangular. Essa superfície deformava meu rosto e partes do corpo expostas em alguns momentos. I rregularidades em sua superfície surgiam como sulcos, buracos, tinta que ia escorrendo, pintando e manchando ao acaso as partes do gelo antes lisas e sem tinta. Tudo isso interferindo ao vivo no autorretrato projetado. Sim, era isso o que procurava. Porém, havia problemas a serem resolvidos: 
quando parte do gelo derretia, a projeção recaía na superfície atrás dela, criando uma espacialidade na projeção. Essa característica também me interessou e foi posteriormente usada em outros trabalhos, mas nesta série de autorretratos queria que a imagem fosse sumindo nos locais em que a superfície do gelo havia derretido.

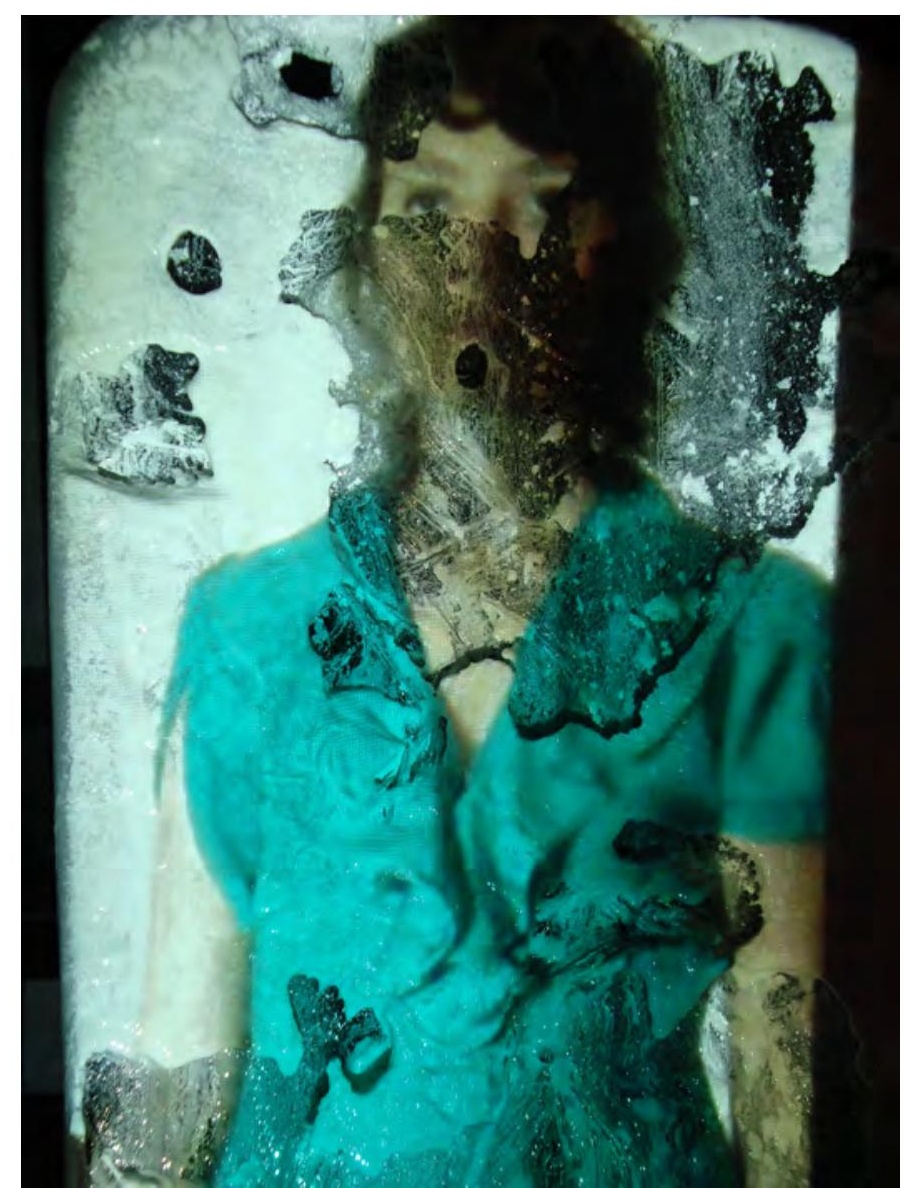

Passei então a fazer estudos de superfícies que poderiam me oferecer essa qualidade de desaparição ou que chegassem mais próximo disso. Fiz testes com papéis escuros, tecidos diversos colocados atrás do gelo. A superfície que me ofereceu a característica pretendida foi um tecido preto todo irregular e felpudo. A projeção que recaía aí quando o gelo derretia ficava bem difusa.

Outra questão apareceu: em que superfície poderia apoiar a tela ou as telas de gelo e apresentá-las? Cheguei a dois resultados: Na obra I de autorretrato, que comentarei logo a seguir, utilizei um suporte bíblico para apoio da tela. No decorrer do tempo, a tela ficava com formatos bem diferenciados, deformava bastante, quebrava em várias partes. Com esse apoio, a tela ia adquirindo sulcos e deformava mais, pois aos poucos tomava a forma do suporte em que foi apoiada.

Também desenvolvi uma caixa com certa profundidade em que a tela ficava a frente e o tecido felpudo que possibilitava a difusão do autorretrato projetado quando o gelo derretia ficava no fundo da caixa. Foram também feitos pequenos furos nessa caixa para que a água do gelo derretido escoasse por eles e gerasse os sons da obra ao vivo, assim que as gotas caíssem em um recipiente colocado abaixo e a certa distância, marcando assim sonoramente a passagem do tempo através dos sons das gotas. Essa forma é a que mais utilizo nas apresentações.

Testes da projeção no gelo da série "Autorretrato com duração e sons variáveis" 
Essa série, como já comentado, é composta de autorretratos em vídeos projetados sobre uma ou mais telas de gelo (ver Autorretrato com duração e sons variáveis III, em que três telas de gelo são utilizadas). A série, até o momento, compreende cinco obras.

As telas são produzidas com água e tinta congelada.

Os vídeos ficam projetados em looping até o derretimento total das telas. Assim que isso acontece, a projeção é desligada, retomando-se sua exibição após a troca da(s) tela(s) quando é o caso (isso depende de quantas apresentações vão ocorrer).

Essa série foi iniciada antes de minha entrada no mestrado e foi estudada nele. Porém, a abordagem recaiu mais enfaticamente sobre a expansão dos modos de exibição das imagens em movimento.

O autorretrato sempre acompanhou o ser humano. Sempre houve o desejo de registrar a nossa existência. As demarcações de mãos nas cavernas apontam para esse desejo. A forma utilizada para registrar e exibir fragmentos de nossa existência varia de geração para geração, de artista para artista, cultura etc. Há artistas que se retratam em seu atelier trabalhando, outros não nos deixam saber em que espaço estão. Alguns deixam visíveis seus instrumentos de trabalho, como pincéis, paleta e espelho utilizado quando é o caso.

Alguns artistas fazem poucos autorretratos, outros fazem constantemente observações de si através de imagens e/ou anotações. As mudanças de atitude em relação à produção de autorretratos apontam para mudanças em todos os âmbitos da vida, como a época em que tal artista estava inserido, conceitos de identidade, valores, estado da arte dentro de pesquisas formais, estéticas e conceituais de uma época.

De uma forma geral, o autorretrato também é uma busca de si mesmo, de se ver, de se apresentar, mas mais que isso é um olhar para si que provoca o olhar relacionado ao mundo e ao outro. Alguns artistas se representam como outro, trazendo questões sobre a construção ou afirmação de identidades. As ambiguidades do ser humano, sejam elas físicas, psíquicas, sociológicas, econômicas, históricas etc., são trabalhadas nesses autorretratos, pois o indivíduo é composto de alteridades.

Embora uma única imagem ou muitas imagens não sejam capazes de guardar toda informação sobre aquele ser ou sobre o que ele é de fato, elas podem sim guardar resquícios de uma época, de um dia significativo, de maneiras de ver e lidar com arte, de seus procedimentos e de mudanças que ocorrem no modo de se retratar para além das mudanças físicas. Materializam-se assim possíveis buscas. Trabalhar com autorretratos durante a vida é uma busca, um experimento poético existencial, um processo que alguns artistas desenvolvem. 
Vários foram os artistas que produziram autorretratos em algum momento ou no decorrer de suas vidas: Albrecht Dürer (1471-1528) J an van Eyck (1390-1441), Van Gogh (1853-1890), Egon Schiele (1890-1918), Frida Kahlo (1907-1954), Lucien Freud (1922-2011) etc. Porém, alguns realizaram autorretratos no decorrer da vida trabalhando questões sobre efemeridade, fugacidade, devir.

Rembrandt Harmenszoon van Rijn (1606-1669) realizou um número significativo de autorretratos no decorrer de sua vida. Desde quando o artista tinha 23 anos de idade até seus últimos dias, em que se apresenta com pele marcada, cabelos brancos, Rembrandt dizia: "Quererão saber que espécie de pessoa eu fui". (apud CANTON, 2002, p. 27)

Pela sua fala fica mais claro que um de seus propósitos era mostrar seus "eus" através das mudanças de expressão, de posturas, tipo de pincelada e forma de trabalhar que aparecem nas imagens. Sendo um artista, essa marca está em seus trabalhos; é sua forma de entender e produzir arte e mostrar seu olhar sobre si mesmo em diferentes momentos.

A série "Autorretrato com duração e sons variáveis" pretende também trabalhar a passagem do tempo, do corpo, de forma ritualística, mostrando o estranhamento por não ser um autorretrato estável e por não durar.

Embora exista um vídeo-registro da ação para cada obra da série e que é projetado no gelo a cada exibição, é durante a apresentação in loco que de fato o trabalho existe e há uma distinção entre a imagem original e a imagem que se apresenta. A imagem não é só uma ampliação e uma projeção. A imagem ocorre no encontro entre projeção e superfície. Essa característica é fundamental para este trabalho.

A imagem é de certa forma sempre atualizada e se mostra no presente a partir de um "registro" passado. A memória fluida, fugidia e passível de ser alterada de acordo como a tonalidade afetiva também é resgatada simbolicamente nesta obra.

Além da simbologia da água ligada à instabilidade, fluidos e renovação, a obra também considera as características físicas do material em si como transparência, mudança de estado, deformações, instabilidade etc. 


\section{Descrição de cada obra da série:}

\section{Autorretrato com duração e sons variáveis I , 2011}

A obra número I desta série foi realizada em 2011 e exposta no $39^{\circ}$ Salão de Arte Contemporânea Luiz Sacilotto, no mesmo ano. O vídeo, que apresenta minha imagem sentada em uma cama, onde realizo poucos movimentos como os de piscar, mover levemente a cabeça, é projetado em uma tela de gelo. Esta obra da série teve dois modos de exibição da tela. Em um deles ela foi apresentada apoiada em suporte bíblico e em outro foi apoiada em uma caixa preparada por mim.

Viviane Vallades. Autorretrato com duração e sons variáveis I. Instalação audiovisual. 2011. Vídeo registro do trabalho. Disponível em: < https://www.youtube.com/watch?v=TqHnXP_vYrE >
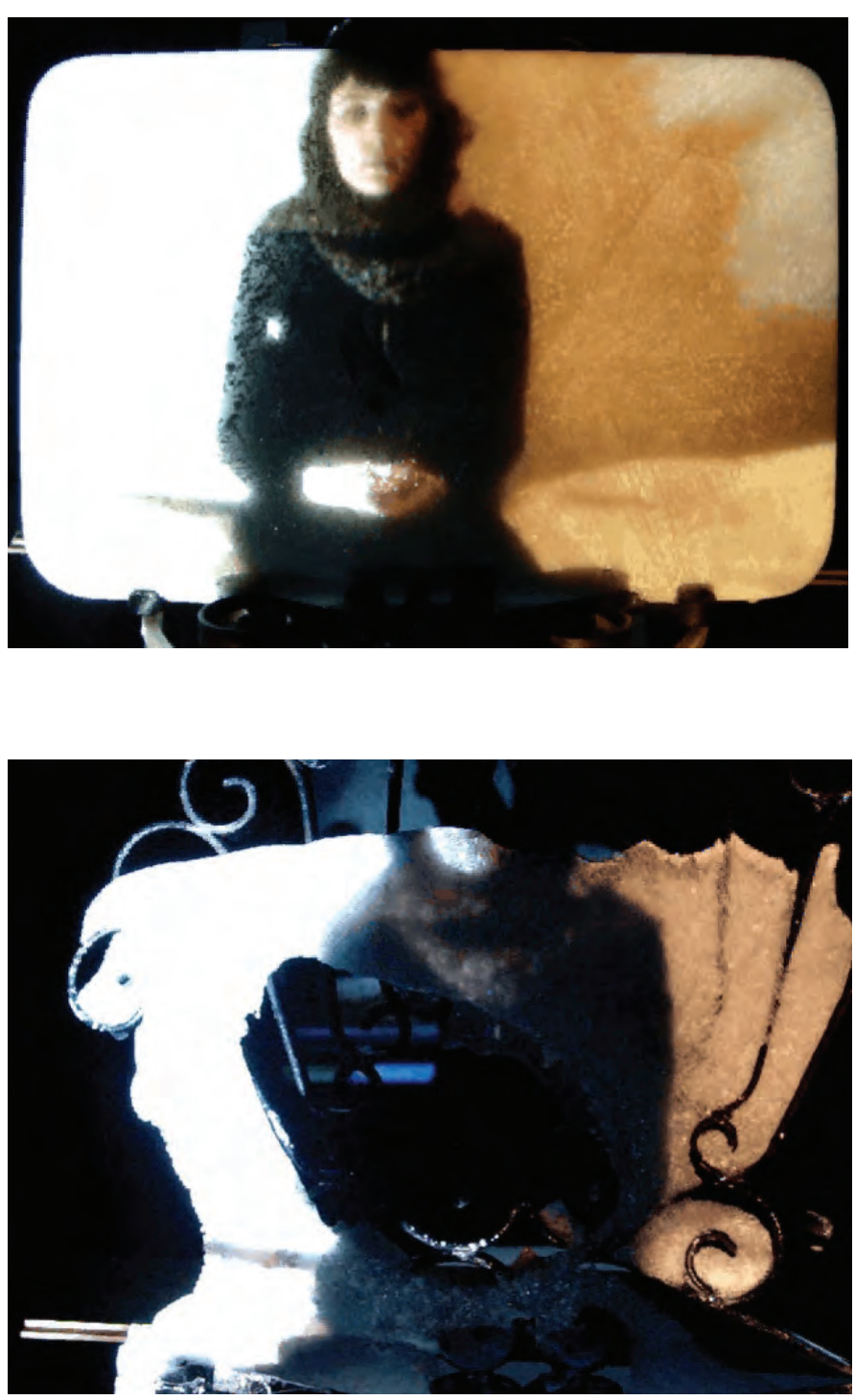


\section{Autorretrato com duração e sons variáveis II,}

\section{2}

Nesta obra da série estou de frente e mirando a câmera. Quase não realizo, também, os movimentos, exceto os de piscar e de me mover lentamente. A imagem fica levemente flutuante devido à gravação ter sido realizada com a câmera na mão. Aliás, esta particularidade é ressaltada na visualização da imagem, não havendo aqui o objetivo de esconder ou camuflar esse procedimento. Este trabalho foi exposto no $28^{\circ}$ Salão Nacional de Artes Plásticas de Embu das Artes em 2012.

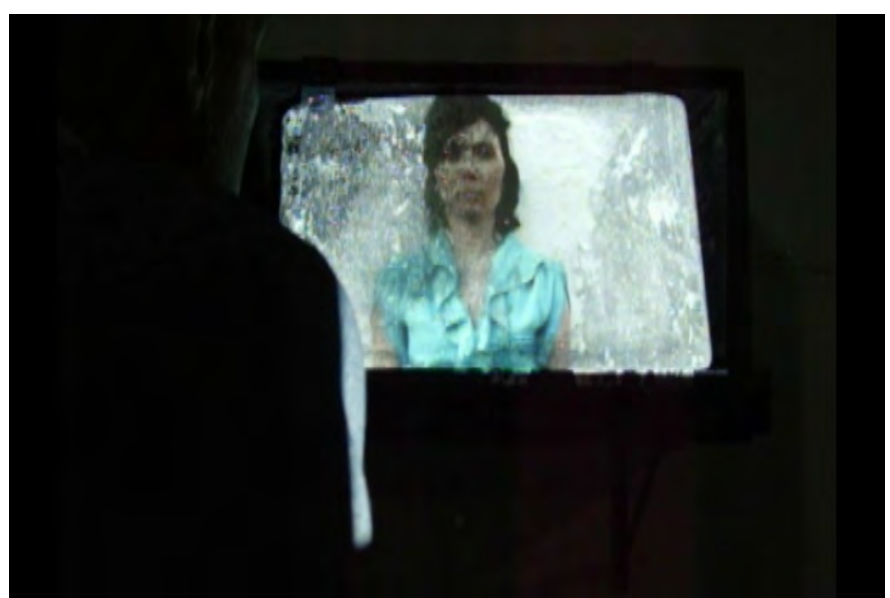

Viviane Vallades. Autorretrato com duração e sons variáveis II. 2012 Vídeo registro do trabalho. Disponível em < https://vimeo.com/52855339 > 


\section{Autorretrato com duração e sons variáveis III ,}

2012

Esta obra da série é constituída da projeção de meu corpo inteiro e flutuante sobre telas de gelo. Três vídeos projetam cabeça, tronco e pernas em looping simultaneamente sobre três telas de gelo, apoiadas em três caixas separadas e alinhadas na vertical com espaço de aproximadamente $0,5 \mathrm{~cm}$ entre elas. Esta obra foi exposta na Exposição “Desdobras", Casa do Cactus, no ano de 2014. Nela foi utilizado o videomapping para as três projeções simultâneas de partes do corpo. 

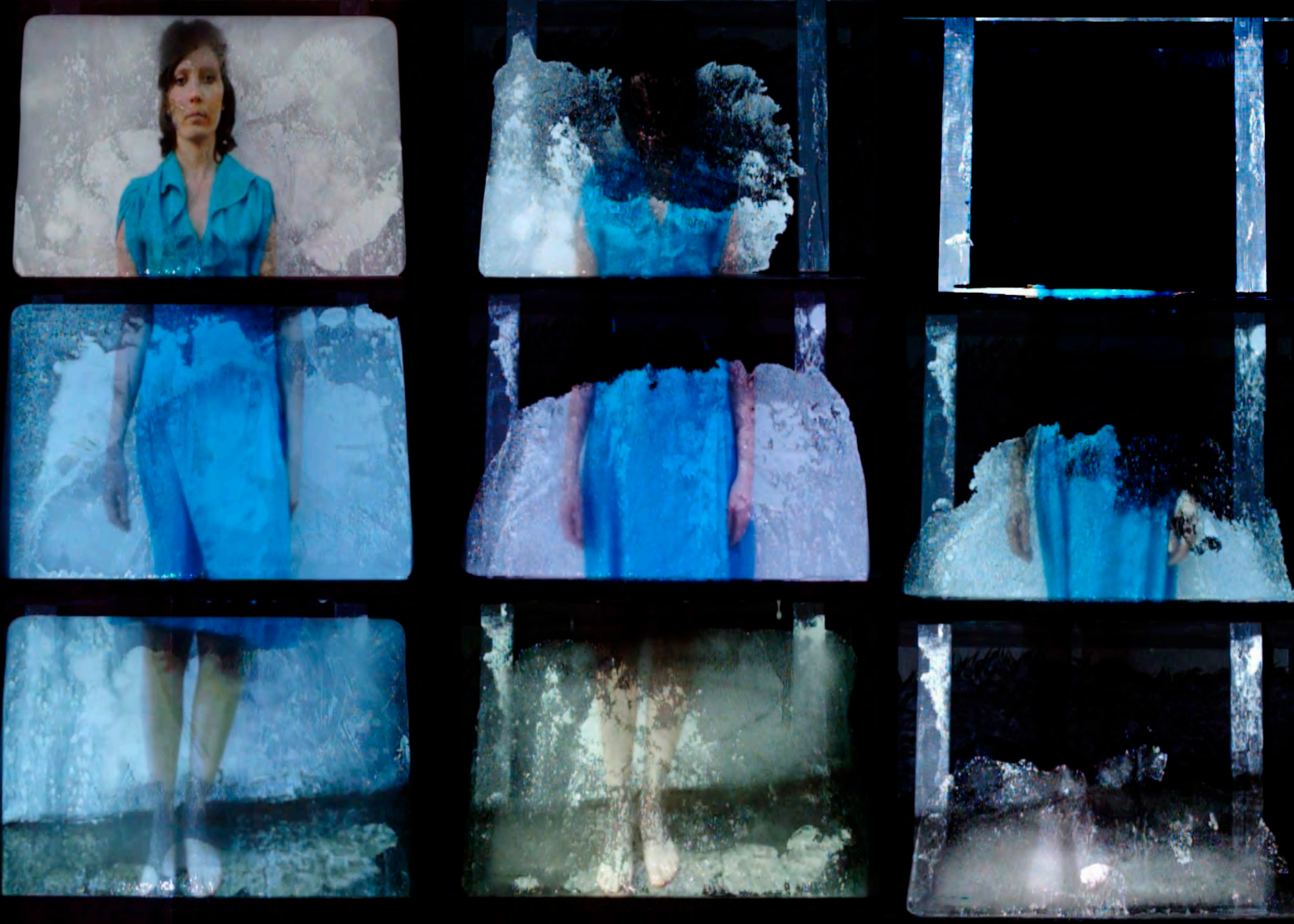


\section{Autorretrato com duração e sons variáveis IV, 2014}

Esta obra da série consiste em um vídeo projetado em uma tela de gelo. Nele caminho lentamente em direção a um espelho, me observo por algum tempo e me afasto. Essa ação fica em looping.

Esta obra foi selecionada para participar da exposição coletiva da $22^{a}$ edição do Programa Nascente da USP em agosto e setembro de 2014, no Centro Universitário Maria Antonia. Ganhou menção Honrosa no 13 Salão de Guarulhos.

Viviane Vallades. Autorretrato com duração e sons variáveis IV. 2014 Vídeo registro do trabalho. Disponível em < https://www.youtube.com/watch?v=hxnmicdM7wQ >
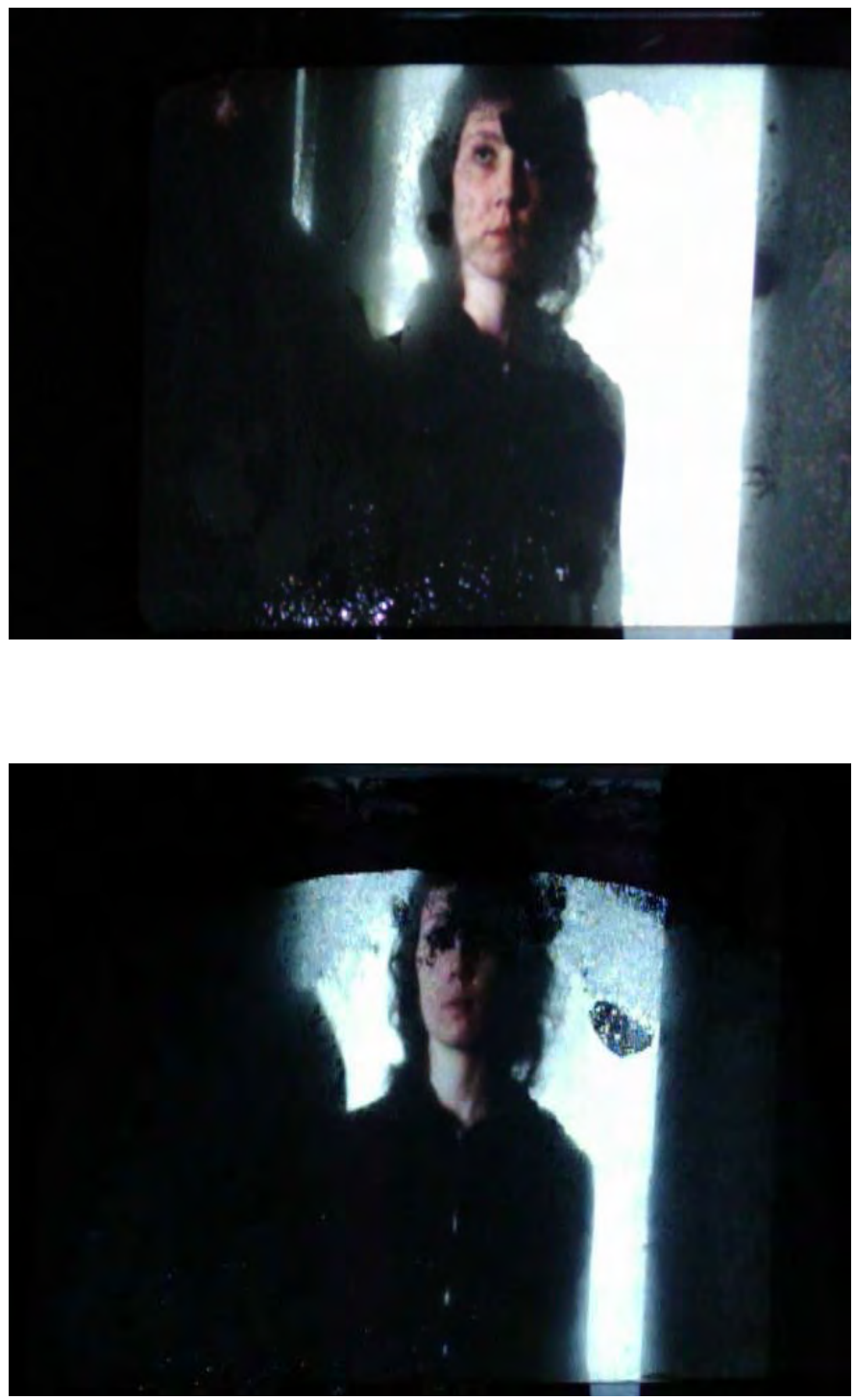


\section{Autorretrato com duração e sons variáveis V, 2019}

Esta obra da série consiste em um vídeo projetado em uma tela de gelo. Realizo poucos movimentos, como os de piscar e respirar diante da câmera, e projeto esse vídeo na tela de gelo. A tela nesta obra da série é constituída de água e tinta preta congelada.

Viviane Vallades. Autorretrato com duração e sons variáveis V. 2019 Registro curto da obra que dura aproximadamente 1 hora https://www.youtube.com/watch?v=Z7OhOBmMOIw
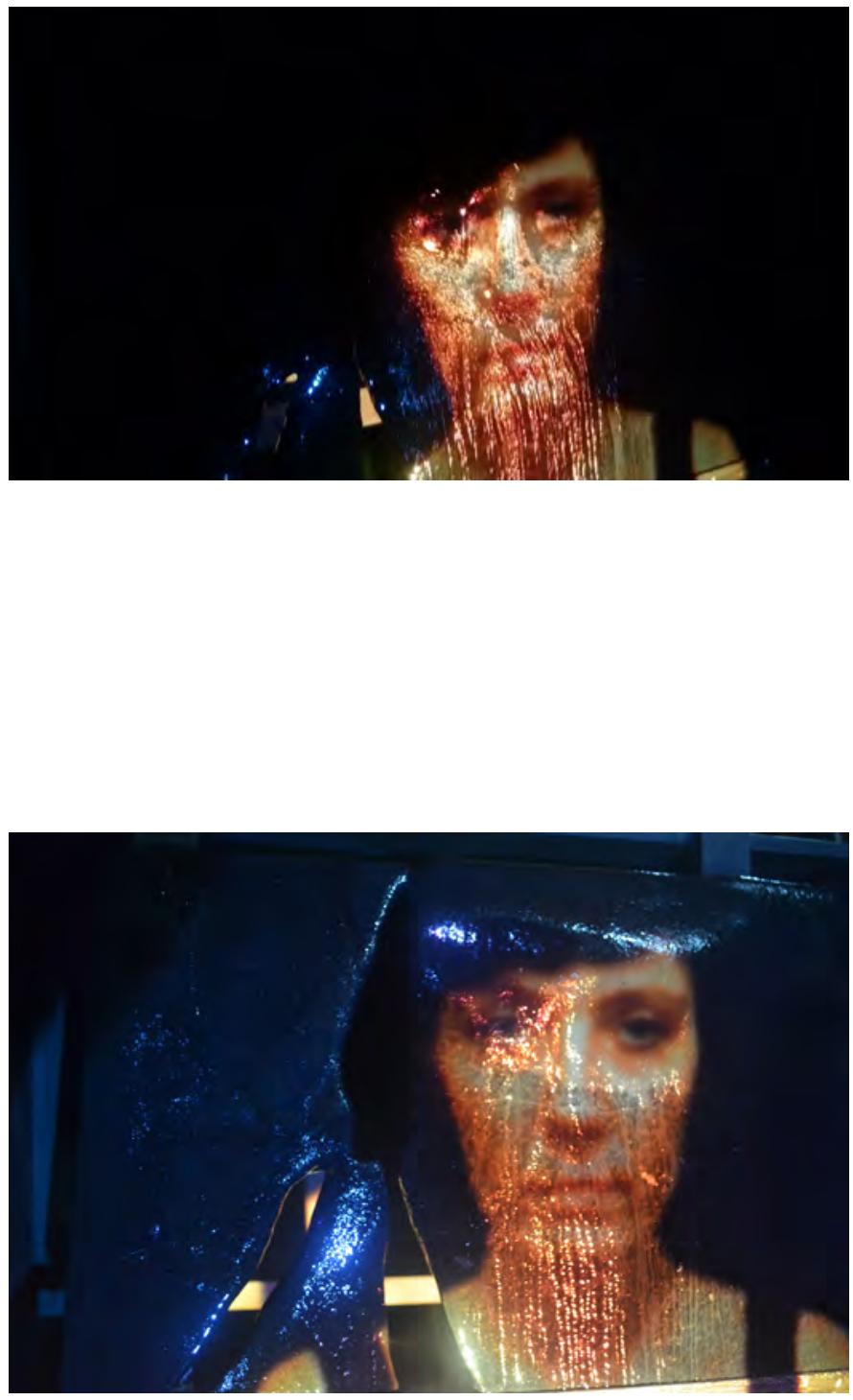
1 Dua

pryar 0 vine qu lii do eselle no owno ir pl froule sigume? exple e depir segrar $1 \frac{\text { anma }}{d e}$ pere ser de karkes $t$ andand a woiker il don inperiog are it a inger refletial qu declege, denowe c que ou no gole ner crue. que maser,

fign 2 the a 2 pofy a


Capítulo 2:

\section{Reflexões \\ do corpo}

"O espelho, são muitos $[\ldots]$ "

Guimarães Rosa (1988, p.65)
2.1 Sem Título, 2015.

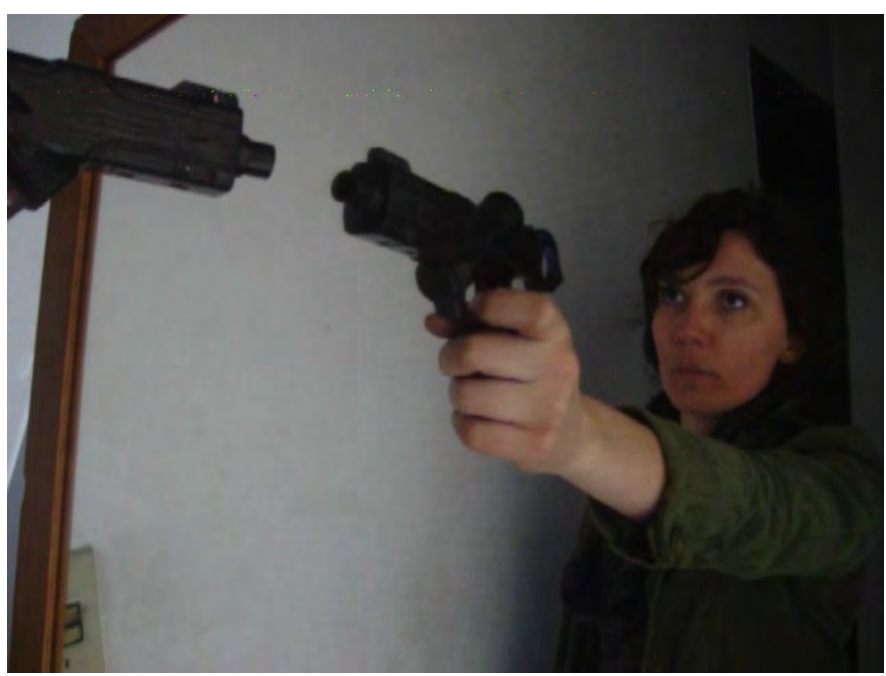

O vídeo "Sem Título" de 2015, na foto acima, surgiu após ter feito uma série de três vídeos utilizando espelhos no ano de 2011, que descrevo a seguir. $\mathrm{Na}$ série de vídeos do ano de 2011 caminho segurando um espelho grande, quase do meu tamanho. No vídeo 1 da série, apareço segurando esse espelho caminhando pela minha casa. Realizo uma espécie de dança / caminhada com o duplo. Neste vídeo, ora pareço manipular o duplo no espelho para guiá-lo em tal direção e ora o duplo parece guiar-me em outra direção até o final do vídeo. Devido ao tamanho do espelho e a seu peso, é um 
tanto difícil carregar o duplo e tudo atrelado a ele, tanto metaforicamente como fisicamente. No vídeo 2 da série, caminho com o mesmo espelho por uma laje, num dia de muita ventania, e realizo posteriormente edições com sobreposições diversas dos vídeos captados, trabalhando o que o espelho fornece de imagem atrás de mim e o que ele esconde da paisagem à frente. O espelho é aí o elemento principal de produção/ edição de imagens e espaços (o espelho é um atrator de imagens).

No terceiro vídeo, caminho em minha casa novamente, só que no escuro, segurando um lampião que deixa visível apenas parte do meu reflexo e do espaço.

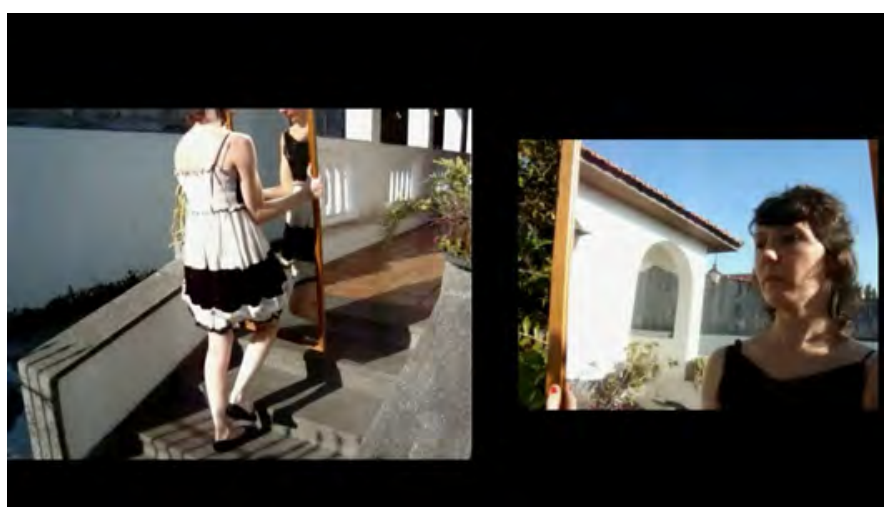

Sem Título I, ano 2011, duração 05'00" câmera: Mercedes Espirito

https: //www. youtube. com/watch?v=JPvK5J aC4U8\&feature=youtu. be

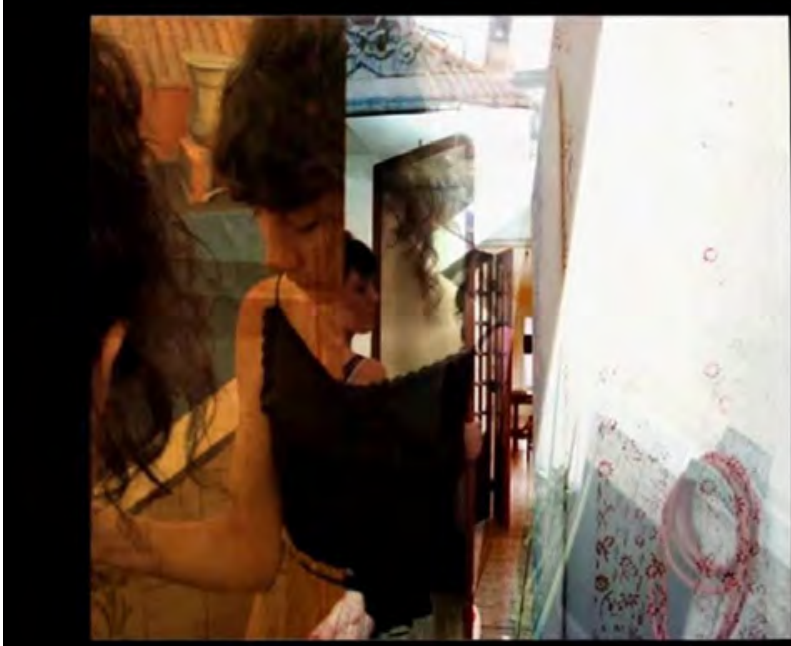

https://vimeo.com/58820758

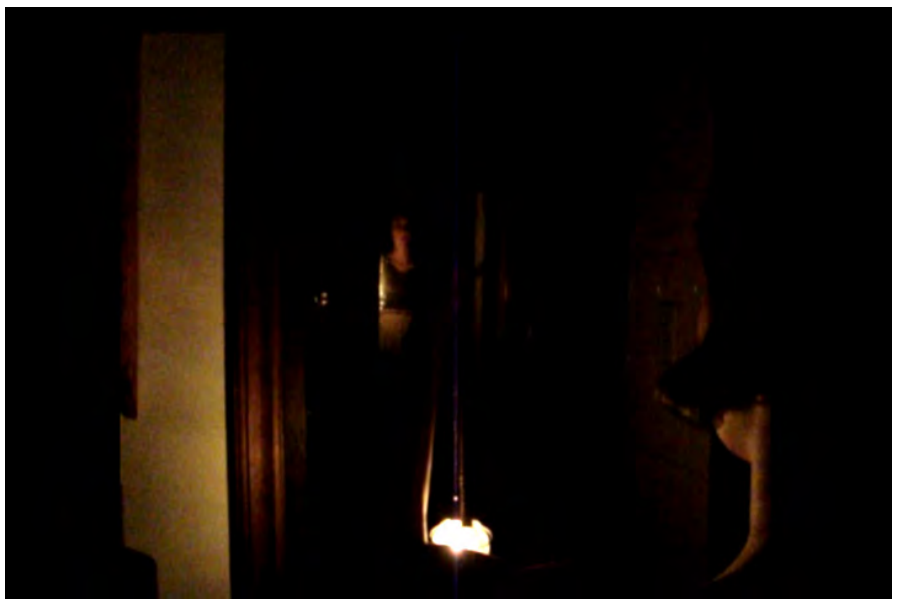

Sem Título III, ano 2011, duração 03'58" câmera: mercedes espirito https://www.youtube.com/watch?v=-rGHVb-LOhw\&feature=youtu. be 
Foi a partir da série e mais especificamente do vídeo três da série em que trabalho mais fortemente com a questão do olhar-se no espelho para metaforicamente trabalhar o entendimento do que somos e do que nos tornamos que tive posteriormente o insight para o vídeo "Sem Título", de 2015, que apresento nesta tese, no qual apareço em um corredor estreito a perseguir meu reflexo em um espelho em movimento, mirando-o com uma arma de brinquedo apontada e preparada para um possível disparo. Essa perseguição acaba também por incluir a imagem refletida (minha imagem) e o fundo. O fundo é o mundo simbolicamente. Essa inclusão do fundo e ampliação do que poderia ser visto nas imagens é uma característica dos espelhos, que são próteses que aumentam nosso campo perceptivo. "O espelho, nesse sentido, é uma prótese, absolutamente neutra, e permite que se obtenha o estímulo visual onde o olho não poderia alcançar (a frente do próprio corpo, atrás de um canto, uma cavidade) com a mesma força e evidência." (ECO, 1989, p. 17 -18)

Os espelhos são próteses neutras, porém o olhar individual que temos quando nos deparamos conosco mesmos, em frente de um espelho, vem simultaneamente seguido da supervisão dos outros ou do que sabemos teoricamente sobre o olhar dos outros baseando-nos nos valores vigentes. Sempre que nos olhamos, nos comparamos, tomamos por referência os outros, a moda, o que é melhor vestir, aparentar ou não. Todas as referências culturais, normas etc. aparecem simultaneamente a esse olhar. Essa relação de olhar para si no espelho e para fora do espelho como uma referência para olhar novamente para dentro do espelho, como um reconhecimento de si, é estudada por Lacan no que ele chama de "estádio do espelho". O estádio do espelho acontece numa relação com nós mesmos e os outros. Segundo Lacan, a criança com menos de um ano de idade se vê diante do espelho várias vezes e nesses embates há diferenças de se relacionar com o duplo. Em um primeiro momento, a criança olha e não distingue aquela imagem como algo diferente de outros objetos. Num segundo momento, acredita que aquele ser do espelho é um outro. E num terceiro momento, ou num terceiro ritmo dessa relação, a criança observa-se a sorrir, por exemplo, e direciona seu olhar para fora do espelho e esse olhar é para um adulto, possivelmente alguém próximo e que atesta que a imagem do espelho é da criança, e este outro fora do espelho pode até complementar nomeando o dono daquele reflexo, apontando e dizendo o nome do bebê que aparece ali refletido.

Assim, o eu é também o produto de reconhecimento do outro. Nesse movimento, a criança reconhece sua borda de corpo, seu limite corporal e distingue o seu eu do corpo de outros. Esse é um momento importante para se distinguir e se relacionar com o outro.

O espelho é um elemento crucial para essa experiência e, como acrescenta Guimarães Rosa, “o espelho, são 


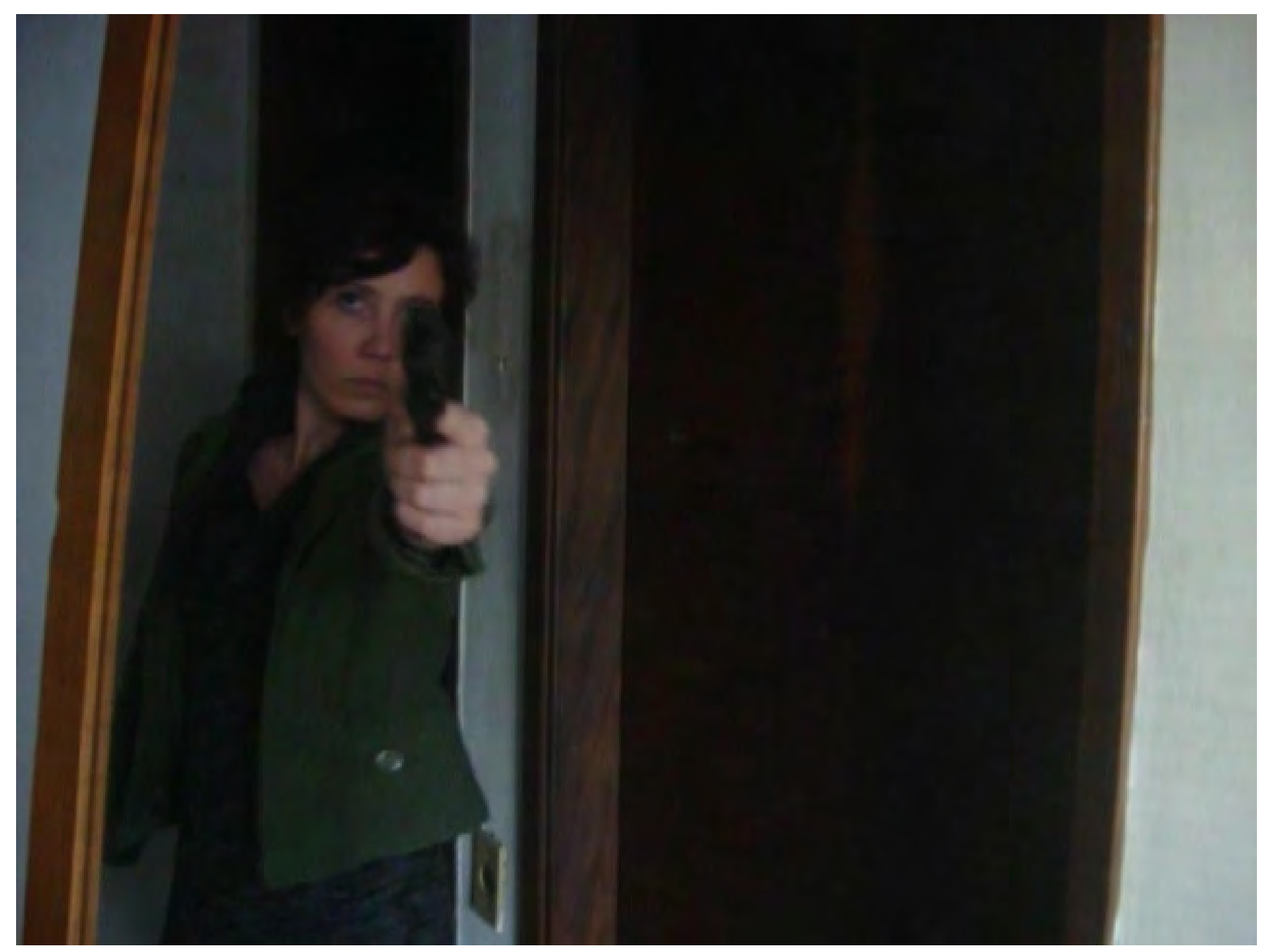

Frames de Sem Título, ano 2015 duração 04'25" https: //www. youtube. com/watch?v=LtPi-MVhG50 
muitos" (1988, p.65). O espelho pode ser estendido a tudo aquilo que é capaz de devolver sua imagem. O olhar do outro, e tudo aquilo que lhe apresenta e o faz distinguir-se do outro, que faz com que você se reconheça, pode ser considerado espelho. O eu se estabelece como produto de relações. Essa distinção também é comparativa e de valores.

A partir daí, a cada aparição no espelho individual surge a "aparição coletiva". Procuro refletir com esse trabalho e com o "Autorretrato com chave de fenda", que comentarei mais a frente, um pouco sobre essa aparição coletiva que vem recheada de valores, status, modelos que nos constroem, mas que acabam também nos sufocando.

Essa aparição coletiva com noções e valores do que é belo ou não é, por exemplo, se apresenta a meu ver no conto de "Branca de Neve e os sete anões", na versão dos irmãos Grimm (1996). No conto, o espelho é um ser mágico e falante que é capaz de saber responder de imediato o que a rainha lhe pergunta. Ela diz:

"Espelho, meu espelhinho,

Me diga: no meu reino

Quem é a mulher mais bonita?"

E o espelho um dia Ihe respondeu de forma diferenciada do que costumava responder:

"Você, rainha, é a mais bela aqui, mas a Branca de Neve, que está morando com os sete anões bem longe, é mil vezes mais bela". (GRIMM, 1996, p.48)
Desta forma, o espelho (deixando de lado um pouco o fato de ser mágico) compara, responde e diz quem é a mais bela, portanto ele é detentor e juiz do conceito de beleza. Se há uma resposta para isso, ela é ligada ao cultural, ao social, ao gosto de uma época, e esse gosto, essa norma, age sobre o nosso olhar diante do espelho, sobre a maneira com que nos olhamos/classificamos.

Os contos ressaltam os problemas sociais, políticos e econômicos de uma época. Nesse conto, há tudo isso envolvido, mas há um destaque para a beleza e a vaidade. Atualmente, também muitos problemas de ordem política, social, cultural se misturam, mas a aparência é fundamental e há um superinvestimento no corpo. “Desde algumas décadas, o foco do sujeito se deslocou da intimidade psíquica para o próprio corpo. Hoje, o eu é o corpo. A subjetividade foi reduzida ao corpo." (PELBART, 2007, p. 60)

Longevidade, saúde, aparência são as principais preocupações dos sujeitos. Nem mesmo as celebridades que são as referências, os modelos e que são popularizadas pela mídia aguentam manter os padrões de beleza. Peter Pál Pelbart chama isso de um "corpo fascista", ou seja, um corpo inalcançável que, na maioria, as pessoas não atingem e portanto são lançadas numa condição de inferioridade sub-humana.(PELBART, 2007, p.60).

A preocupação com o corpo e o que ele reflete, 
principalmente na aparência, ganhou destaque. Siegfried Kracauer ${ }^{1}$ já prevê essa preocupação no final da década de 1920:

a corrida aos inúmeros salões de beleza nasce, em parte, de preocupações existenciais, e o uso de cosméticos nem sempre é um luxo. Por medo de caírem em desuso como obsoletos, senhoras e cavalheiros tingem o cabelo, enquanto quarentões praticam esportes para se manterem esguios. 'Como posso ficar bela?', indaga o título de um folheto recém-lançado no mercado; os anúncios de jornal dizem que ele apresenta maneiras de "permanecer jovem e bonita agora e para sempre. (apud BAUMAN, 2008, p.13-14).

Ao nos avaliarmos no espelho, além da beleza e da aparência, que são pontos em destaque na contemporaneidade, trazemos também questionamentos de cunho social: Estou bem para tal evento, passo a imagem, a postura pretendida? Somos tomados por um olhar social sobre nós mesmos, formado a partir do que a sociedade respeita e admira, como um cargo profissional, por exemplo. O olhar para o espelho para pensar o individual e o coletivo (que é modelo para o individual) aparece fortemente em dois contos brasileiros: "O espelho: Esboço de uma nova teoria da alma humana", de Machado de Assis, e "O espelho", de Guimarães Rosa, que comentarei brevemente, pois os dois ajudam a pensar nas questões em que meu trabalho esbarra. Os contos apresentam personagens

1 Kracauer, Die Angestellen, ensaios apresentados em série pela primeira vez no Frankfurter Allgemeine Zeitung em 1929, e depois publicados na forma de livro pela Suhrkamp em 1930. que se defrontam diante do espelho para pensar modos de autoconhecimento e ressaltam questionamentos sobre identidade, papéis sociais e o olhar do outro, assim como faço em meus vídeos.

O conto de Machado de Assis "O espelho: Esboço de uma nova teoria da alma humana", (2006), inicia-se com um debate entre cavalheiros sobre questões de alta transcendência. Dentre esses cavalheiros, um deles, o protagonista, Jacobina, não participava da conversa até o momento em foi instigado a falar e dar uma opinião sobre o assunto em pauta, que era sobre a natureza da alma humana. Ele se propõe a falar disso mediante a ressalva de não ser interrompido, pois ele não discutia. Passou a tratar do assunto e demonstrar, através de um caso de sua própria vida, que existiam de fato duas almas. E assim começou:

Em primeiro lugar, não há uma só alma, há duas [...] Cada criatura humana traz duas almas consigo: uma que olha de dentro para fora, outra que olha de fora para dentro[...].A alma exterior pode ser um espírito, um fluido, um homem, muitos homens, um objeto, uma operação. [...] Está claro que o ofício dessa segunda alma é transmitir a vida, como a primeira; as duas completam o homem, que é, metafisicamente falando, uma laranja. Quem perde uma das metades, perde naturalmente metade da existência; e casos há, não raros, em que a perda da alma exterior implica a da existência inteira. [...]Agora, é preciso saber que a alma exterior não é sempre a mesma [...] muda de natureza e de estado. [...] Há cavalheiros, por exemplo, cuja alma exterior, nos primeiros anos, foi um chocalho ou um cavalinho de pau, e mais tarde uma provedoria de irmandade, suponhamos. (ASSIS, 2006, p. 43-44) 
O caso que lhe ocorreu e fez narrar essa história aconteceu quando ele completou vinte e cinco anos. Ele relata como sua alma exterior e consequentemente a interior mudaram. Até essa idade era pobre, mas foi nomeado alferes da Guarda Nacional, um cargo significativo de acordo com os valores da sociedade. A família ficou muito orgulhosa e passou a chamá-lo de alferes. O personagem comenta que todas as mudanças de tratamento que recebera devido ao novo posto fizeram o alferes eliminar o homem. E explica que a eliminação não aconteceu de uma hora para outra. No começo, as duas naturezas (alma interior e exterior) ainda se equilibravam, mas depois restou-Ihe uma parte mínima de humanidade.

Ele diz:

O alferes eliminou o homem. [...] Aconteceu então que a alma exterior, que era dantes o sol, o ar, o campo, os olhos das moças, mudou de natureza, e passou a ser a cortesia e os rapapés da casa, tudo que me falava do posto, nada do que me falava do homem. (ASSIS, 2006, p.46)

Assim, os problemas humanos e sensíveis não mais o tocavam. Seu interesse voltou-se apenas para os assuntos de seu novo posto e seu novo status. Um convite e os eventos que se seguiram a esse fato fizeram pensar mais ainda sobre essas duas almas, O convite veio de sua tia para que ele passasse um tempo no sítio dela. Lá ela destinou-lhe o melhor quarto e deixou um espelho, obra rica e magnífica que diferia do restante das mobílias da casa em seu quarto, tudo por conta de seu novo posto de alferes. Porém, sua tia recebe um telefonema e teve que partir, deixando Jacobina no sítio com os escravos, que acabam fugindo. Jacobina se vê sozinho e abalado por não ter as bajulações de todos. Decidiu se olhar no espelho ao fim de oito dias. E se viu de forma vaga, difusa, sombra de sombra. Continuou a olhar sua imagem não nítida até que teve a ideia de vestir a farda. Foi quando sua imagem voltou a ter foco. A partir daí, passa seus dias vestindo a farda (seu status) e a olhar-se no espelho, conseguindo passar mais seis dias de solidão sem o sentir, pois restituiu o olhar do outro através do espelho naqueles momentos de solidão. No conto de Machado de Assis, a alma externa, como Jacobina mesmo explica, acaba prevalecendo e sufocando ao extremo a alma interna. Ele só se sentia vivo e tinha a sua identidade quando fardado. O olhar e o respeito dos outros, devido ao seu novo posto, tornaram-se a referência de sua identidade. O personagem passa a se ver apenas a partir do olhar do outro ou do que o outro julga bom (coletivo). O espelho social sufocou sua alma interna.

Indo em direção contrária, no conto "O espelho", (1988) de Guimarães Rosa, o personagem, do qual não nos é revelado o nome, começa falando sobre características dos espelhos e o que supõe serem eles nas leis da física, mas questiona o leitor se ele tem ideia do que seja o espelho em seu aspecto transcendental. Passa por várias descrições de espelhos e conta como passou a 
procurar-se. Ele estava em um lavatório de um edifício público e viu um perfil humano desagradável que surgiu devido ao jogo de dois espelhos, um deles de parede e o outro aberto na lateral em ângulo. Achou aquele ser horrendo, até perceber que aquele ser era ele.

Desde então não parou de procurar-se - o eu por detrás dele. Comenta sobre o olhar-se no espelho que todos nós fazemos, mas que é um olhar que busca "verificar, acertar, trabalhar um modelo subjetivo, preexistente; enfim, ampliar o ilusório, mediante sucessivas capas de ilusão". ( ROSA, 1988, p. 68)

Essa procura que o personagem comenta é semelhante àquela que acontece no conto "O espelho", de Machado de Assis, no qual o personagem tenta se moldar a algum modelo preexistente. Porém, no conto de Guimarães Rosa o personagem diz que esse tipo de busca não lhe interessa, não é o que ele pretende, pois é um pesquisador e se interessa por uma busca científica. Passa a fazer diversos experimentos durante meses. Passou a se olhar por ângulos variados, a golpes de esguelha, olhava-se em momentos diversos como quando estava com raiva, feliz, orgulho abatido, etc. Mas mesmo todas essas experiências em se ver ainda não eram suficientes para o que pretendia: procurar a si mesmo. Parte então para outro método: bloqueios visuais. Começa abstraindo, bloqueando partes que não são próprias dele, que não são sua essência. Começa eliminando a imagem de seu sósia animal, seus traços hereditários, suas paixões, as ideias que os outros lhe atribuem, mas passa a sentir dores de cabeça durante os experimentos e deixa-os um pouco de lado e confessa que talvez tenha os deixado por ter se acovardado.

Deixa de lado o experimento por um período e não se olha no espelho por um tempo. Um dia, olha-se no espelho e não se vê. Posteriormente, passa a ver uma luzinha e depois vai surgindo um rosto, mas não o dele , e sim um "rostinho de menino, de menos de-quemenino, só." (ROSA, 1988, p. 72)

Os dois contos procuram estabelecer uma identidade. Em Machado, o personagem, mesmo que ironicamente, se sente bem apenas quando fardado, com sua máscara social; já no conto de Guimarães Rosa, o personagem quer retirar todas as máscaras e encontrar sua essência.

Nos dois contos, como em meu trabalho, o espelho não está ali apenas como representação visual objetiva e óptica, mas como reflexão de aprovação social, comparativa, e talvez como uma possível aniquilação desse conjunto, através de bloqueios visuais, como no conto de Guimarães Rosa, ou por um disparo ou por um desejo dessa aniquilação, como a arma de brinquedo no vídeo "Sem Título", de minha autoria.

Nos contos e no vídeo que apresento, o espelho reflete questionamentos sobre o que somos e o que não somos e aponta relações entre o corpo e a alma, entre o indivíduo e a sociedade e a reflexão da relação eu/ 
coletivo, questionando se há ou não como separar de fato um do outro.

Aceitar a condição e norma social mesmo que por sarcasmo ou tentar desfazer isso, que pode ser chamado de máscara, é o embate ficcional desses trabalhos. 

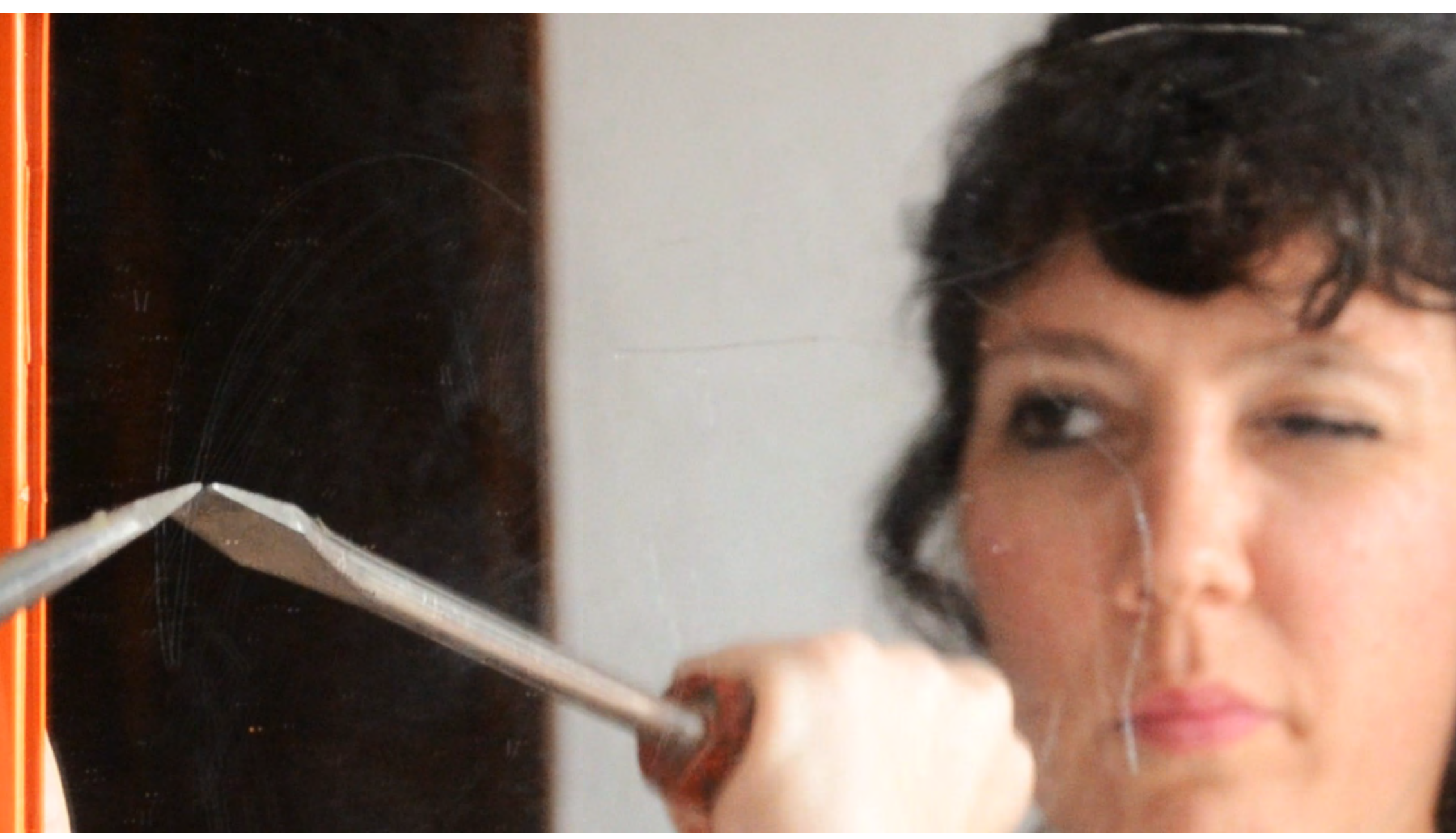

Autorretrato com chave de fenda, 2016, duração 03'00. Câmera: Mercedes Espirito https: //www. youtube. com/watch?v=dZwZGoaFVok\&feature=youtu. be 


\subsection{Autorretrato com chave de fenda}

No corpo estão inscritas todas as regras, todas as normas e todos os valores de uma sociedade específica, por ser ele o meio de contacto primário do indivíduo com o ambiente que o cerca. (Daolio, 1995, p.105)

O autorretrato é muito encontrado em obras de artistas e na história da arte. Artistas se autorretratam ao longo de suas vidas, alguns mais obstinadamente do que outros, como Rembrandt e Van Gogh, por exemplo. Durante a vida de um artista, sua imagem costuma ser utilizada tanto para estudos, por haver acesso ilimitado ao modelo no aperfeiçoamento de técnicas, como também para pensar o que é um autorretrato, no sentido de que pode ter uma ou mais identidades, e refletir sobre o ser, seu estado emocional e as mudanças que ocorrem em nossas vidas e na nossa sociedade. No autorretrato o artista costuma ser o seu próprio modelo, podendo usar uma foto como referência, um vídeo, a imaginação ou um espelho para observação. Muitos artistas inserem-se dentro de suas obras ao longo da história da arte, principalmente pelo uso de espelhos, como Diego Rodríguez de Silva y Velázquez (15991660), Jan van Eyck (1390- 1441).

Instrumentos e materiais diversos são usados para a representação de autorretratos e também ficam visíveis em sua própria representação: pincéis, câmeras fotográficas, videográficas, sangue, etc.
Cada material e gesto para sua feitura causa uma sensação diferente; o artista pode também apresentarse, em um ambiente mais íntimo ou não. Quando na pintura, pode ser um autorretrato pincelado, quase abstrato ou que procura não revelar as marcas da pintura. Com as câmeras fotográficas ou videográficas, eles podem ser com foco ou sem foco. As fotos e vídeos são meios que podem principalmente trabalhar a duração do tempo, de exibição, apresentando o processo de realização desses autorretratos.

Os autorretratos apresentam a imagem de um corpo na maioria das vezes e o modo como esse corpo é retratado diz muito sobre o artista, sua época social e cultural.

Nos retratos e autorretratos é comum se revelar a face ou o corpo do representado. Em meus vídeos, especialmente em "Autorretrato com chave de fenda", o meu rosto fica em evidência diante do espelho durante a tentativa de captura do meu autorretrato.

O rosto é, de todas as partes do corpo humano, aquela onde se condensam os valores mais elevados. Nele cristalizam-se os sentimentos de identidade, estabelece-se o reconhecimento do outro, fixam-se qualidades de sedução, identifica-se o sexo, etc. (LE BRETON 2007, p.70-71)

O rosto, principalmente nesse trabalho, aparece em evidência e assim torna-se possível prever minha idade, meu sexo, meus traços, minha expressão e desenvolver leituras sobre esses elementos. Porém, o que pretendo destacar nesse trabalho é a tentativa de 
um autorretrato que é feito por mim, mas que não deixa de fora mesmo que simbolicamente o olhar coletivo (pois pretendi ir além de meu rosto e meu corpo para refletir sobre as regras e modelos de corpos e de ser que foram embutidos em nós). Pretendi abordar o ato de olhar num espelho e englobar nesse espelho e no ato de rabiscar tudo que vem junto nesse olhar e que pode incomodar. Ao invés de usar materiais como pincéis, canetas etc., escolhi usar materiais cortantes e mais agressivos, como chave de fenda, que em seu percurso gráfico para a produção do autorretrato na superfície refletora produz um som que causa sensações incômodas, arrepios e estranhamento, gerando assim reflexões sobre $o$ ato.

Usar um elemento cortante para se autorretratar também traz a ideia de registrar, deixar marcas, embora não seja uma agressividade no corpo de fato, já que é apenas "desenho", um registro de imagem em uma superfície refletora. O trabalho procura refletir um desajuste cotidiano no ato de encarar-se diante do espelho devido a pressões de vários níveis, sejam elas estéticas, sociais, de status, políticas etc.

No espelho do autorretrato de artista reflete-se a imagem física assim como estados emocionais, contextos sócio-históricos que circunscrevem a obra, além de questionamentos sobre a maneira de se ver e lidar com arte. (CANTON, 2002, p. 34-36)
Usar elementos cortantes e de certa forma agressivos ligados ao corpo é também comum nas obras de vários artistas, principalmente para tratar das políticas do corpo, do corpo social etc. Muitos artistas utilizaram-nos com propósitos de chocar, de causar reflexão como aconteceu principalmente na body art, nas performances nos anos 60 e 70. O corpo associado a elementos cortantes e perigosos foi utilizado para tratar de várias questões, como o culto ao corpo e a beleza, como também para tratar de pressões econômicas e de cunho de status. Embora aparentemente esses autorretratos possam dar a impressão de que estão tratando de apenas um único corpo, pois às vezes é o corpo do artista, pretendem ir muito além disso, pretendem tratar do corpo coletivo. Na maioria de meus trabalhos, meu corpo está presente e a escolha não se deu por ser mais fácil, por estar mais disponível, mas por achar fundamental sentir os gestos, realizar as obras e incorporar de fato o que estou fazendo, pois, no momento do fazer, o corpo passa por sensações, medos, alegrias, e dúvidas. Nem sempre sei ao certo o que vai ocorrer no momento da realização das ações para vídeo, mas sempre penso em questões mais gerais que não só tratam do corpo feminino, pois procuro o coletivo a partir do meu corpo.

Nos trabalhos deste capítulo não há nenhum posicionamento contra a beleza ou ao ato de se cuidar e se sentir bem. Apenas constato que a busca por 
modelos, perfeição, status social etc. pode causar sofrimentos físicos e psíquicos que também aparecem nos duelos travados entre a aparência "normatizada" e o que se é. 
Capítulo 3:

Peles, cascas, máscaras e metamorfoses

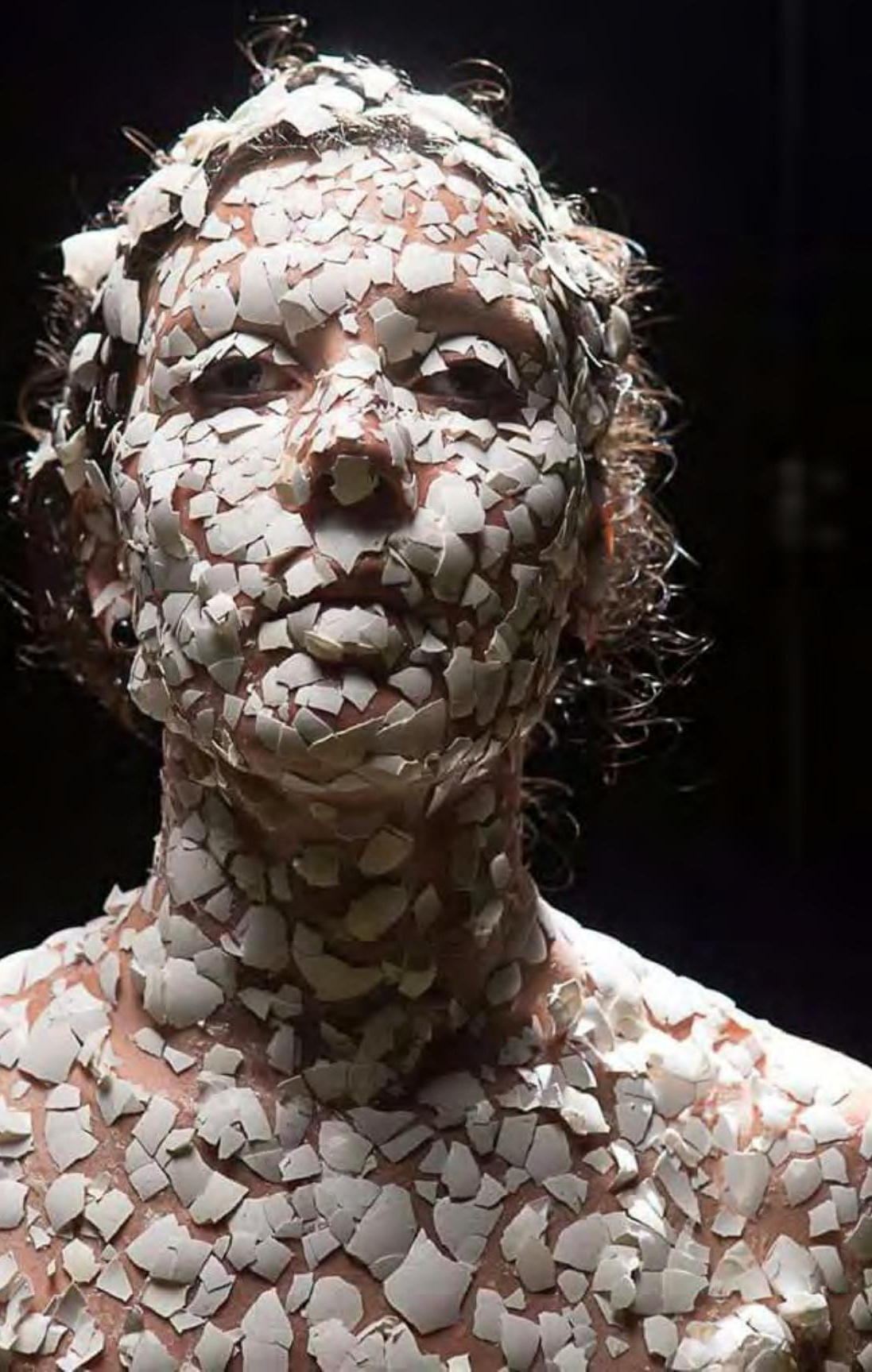




\section{Traduzir-se}

Uma parte de mim

é todo mundo:

outra parte é ninguém:

fundo sem fundo.

Uma parte de mim

é multidão:

outra parte estranheza

e solidão.

Uma parte de mim

pesa, pondera:

outra parte

delira.

Uma parte de mim

almoça e janta:

outra parte

se espanta.

Uma parte de mim

é permanente:

outra parte

se sabe de repente.

Uma parte de mim

é só vertigem:

outra parte,

linguagem.

Traduzir-se uma parte

na outra parte

- que é uma questão

de vida ou morte -

será arte?

Ferreira Gullar (2017, p.30-31) 


\section{1 "Sem Título" (Fotografia)}

O conceito da foto "Sem Título" (imagem que inicia este capítulo) teve início em 2015 durante a realização da disciplina "Arquiteturas do Corpo-máscara, mascaramento, mutação e expansão dos corpos na cena hoje" sob a orientação dos Professores Dr. Felisberto Sabino da Costa e Dr. Marcelo Denny de Toledo Leite.

Escolhi realizar esta disciplina pela proximidade conceitual e temática com meu projeto, que relacionava o corpo e suas alterações com questões existenciais cotidianas, passagens de estados psicológicos e identidades provisórias.

Durante a disciplina foi-nos indicado realizar um trabalho de criação de uma arquitetura para o corpo que tivesse relação conosco, com nosso trabalho poético para que na apresentação final realizássemos um trabalho plástico, conceitual, abordando as questões das aulas que giravam em torno do mascaramento, do corpo em expansão, do corpo modificado. Como finalização haveria um encontro na ECA USP com um fotógrafo para o registro das produções.

No período em que cursei a aula, realizava livremente fotos de ovo, como a indicada nesta página. A figura do ovo estava rondando meu imaginário e rapidamente aderi esse elemento ao meu corpo. O que me interessava nesse elemento quando pensei em aderi-lo ao meu corpo era sua forte carga simbólica sobre renascimento,

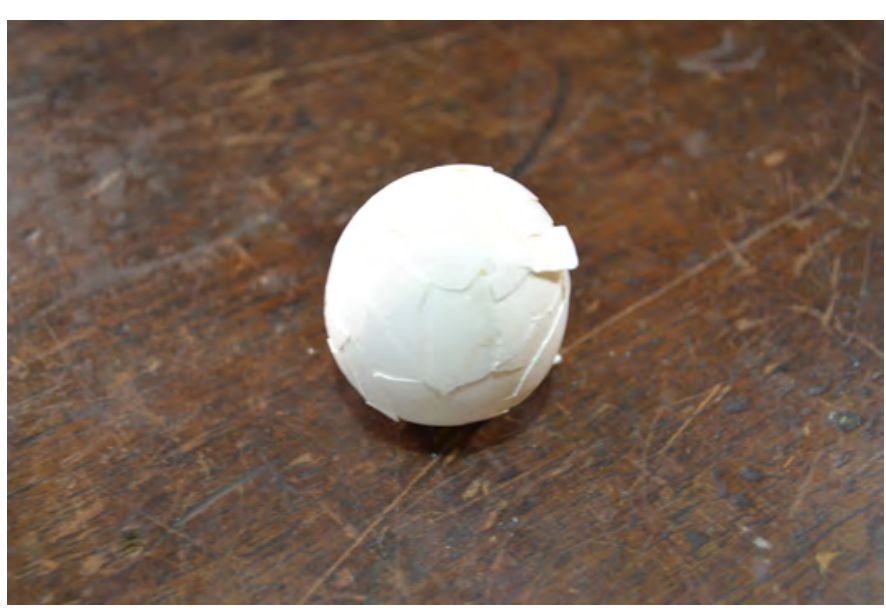

passagens e transformação, além da aparência monstruosa, de ser diferenciado que eu ficara com minha nova pele.

Realizei diversos testes de como poderia aderir essas cascas ao meu rosto e corpo. Fiz testes com cascas irregulares, maiores, menores, tipos de cola que resultariam em extensão da pele e optei por usar cola branca. Fiz o trabalho no dia final da disciplina e tive como resultado a foto que iniciou este capítulo.Para a disciplina finalizei o trabalho apenas com foto de meu rosto totalmente recoberto por cascas de ovo. Porém, a vontade de dar continuidade a esse trabalho e por ser um de meus procedimentos poéticos realizar novos formatos e passagens de um meio ao outro a partir de um mesmo insight, decidi realizá-lo novamente diante de uma câmera de vídeo. 

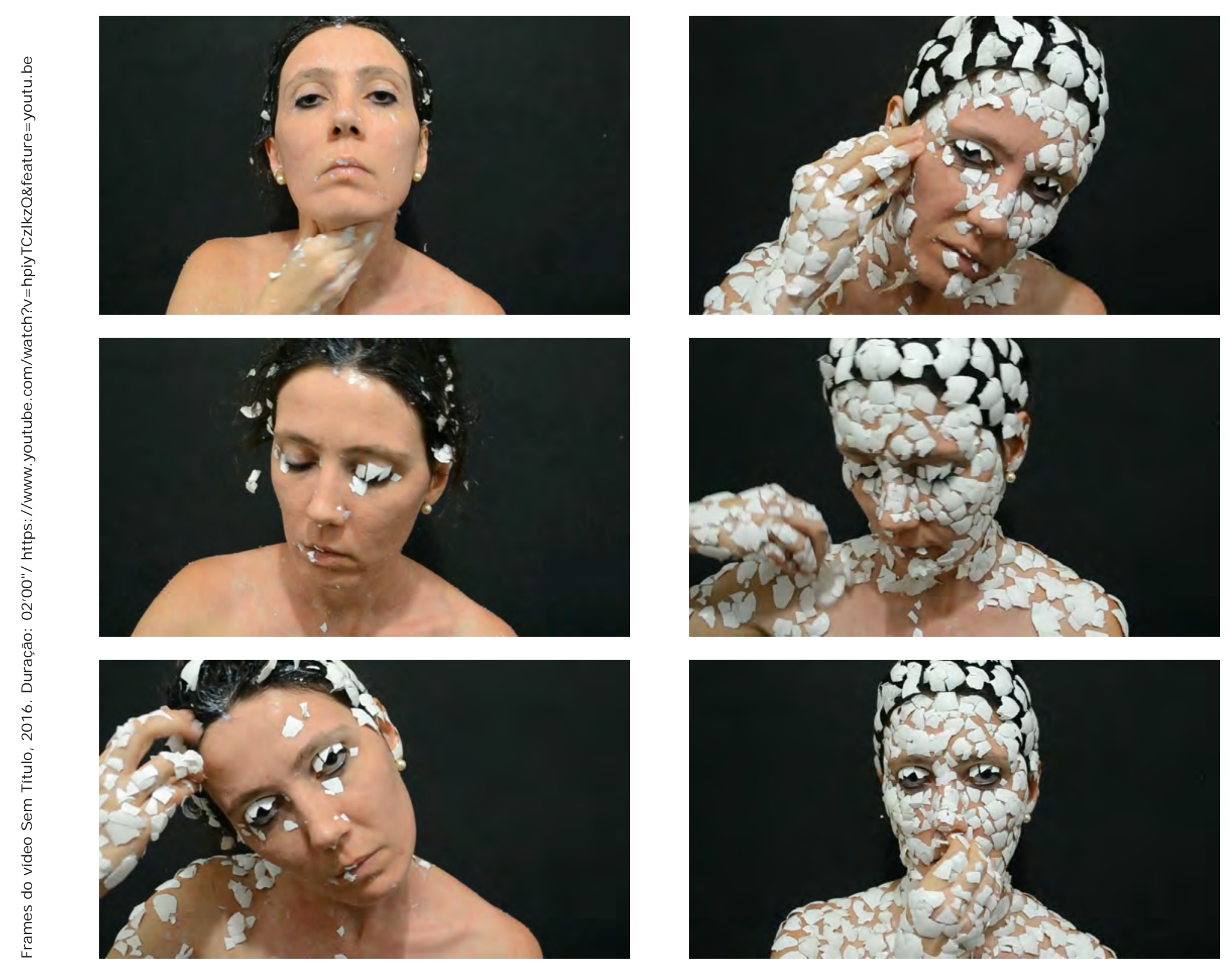


\section{2 “Sem Título" ( vídeo e videoinstalação)}

Nesse momento retirei as cascas de meu corpo durante a ação em vídeo e, por processo de edição, inverti o vídeo do fim para o começo, causando um certo estranhamento na ação através do procedimento reverse de vídeo. Meu corpo aparece assim sem cascas no início do vídeo para no final estar totalmente coberto por cascas de ovo. Com esse procedimento (reverse) na imagem e também no som, a parte sonora adquiriu mais ruídos. O som foi o captado durante a ação. Ele já apresentava ruídos, pois durante a performance jogo as cascas de ovo em uma bacia fora do enquadramento do vídeo. Com o efeito reverse esses ruídos ficaram mais fortes. Realizei mais uma passagem de meios desse vídeo para o formato de videoinstalação. Para isso, acrescentei alguns frames escuros entre a ação de retirar as cascas com o propósito de apresentar o vídeo projetado em uma sala estreita e escura de forma que os observadores ficassem próximos da imagem projetada e que essa aparecesse de supetão em alguns momentos para retornar à escuridão novamente. Isto causou uma aparição imagética repentina e ruidosa (através do som do vídeo).

O vídeo e a videoinstalação foram realizados a partir do mesmo material captado. Realizei a ação de retirar as cascas de ovo diante da câmera com enquadramento fixo e frontal por cerca de 15 minutos, utilizando um tripé com monitoração de Regina Vallades durante toda a captação. Adicionei uma peça de madeira, que pintei de preto fosco atrás de meu corpo, de forma a deixar a pele e o ovo em destaque. Esse material captado foi editado para o vídeo e para a videoinstalação. Na edição utilizei 64 camadas de imagem para realizar os cortes do vídeo captado. Em algumas das partes da ação fiz mudanças na escala do vídeo (zoom). Decidi colocar uma camada só para imagem e uma camada só para o som para cada fragmento cortado de forma a ter mais controle, caso fosse necessário algum corte no som ou na imagem separadamente.

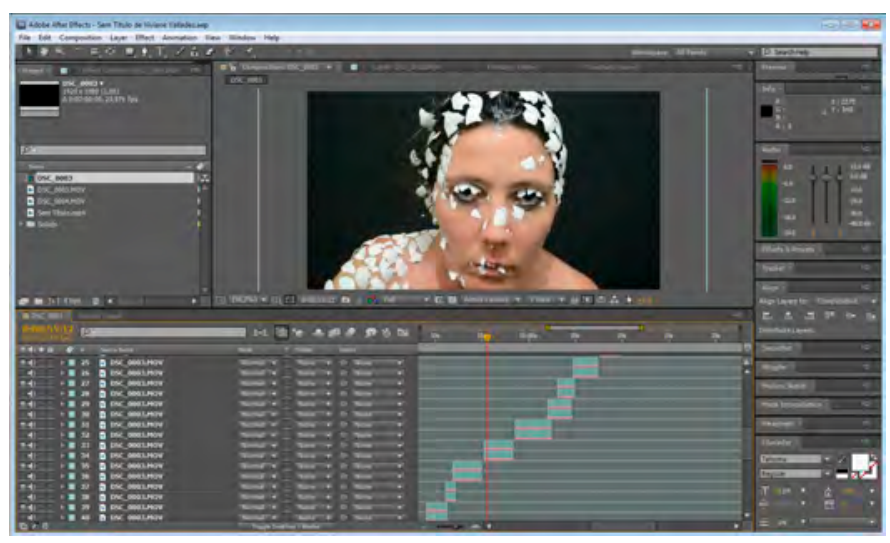

Para a videoinstalação realizei processo semelhante, porém com a adição de frames pretos entre alguns cortes do vídeo captado. O som na videoinstalação foi deixado constante (com ruídos) mesmo quando a imagem do corpo desaparecia. 


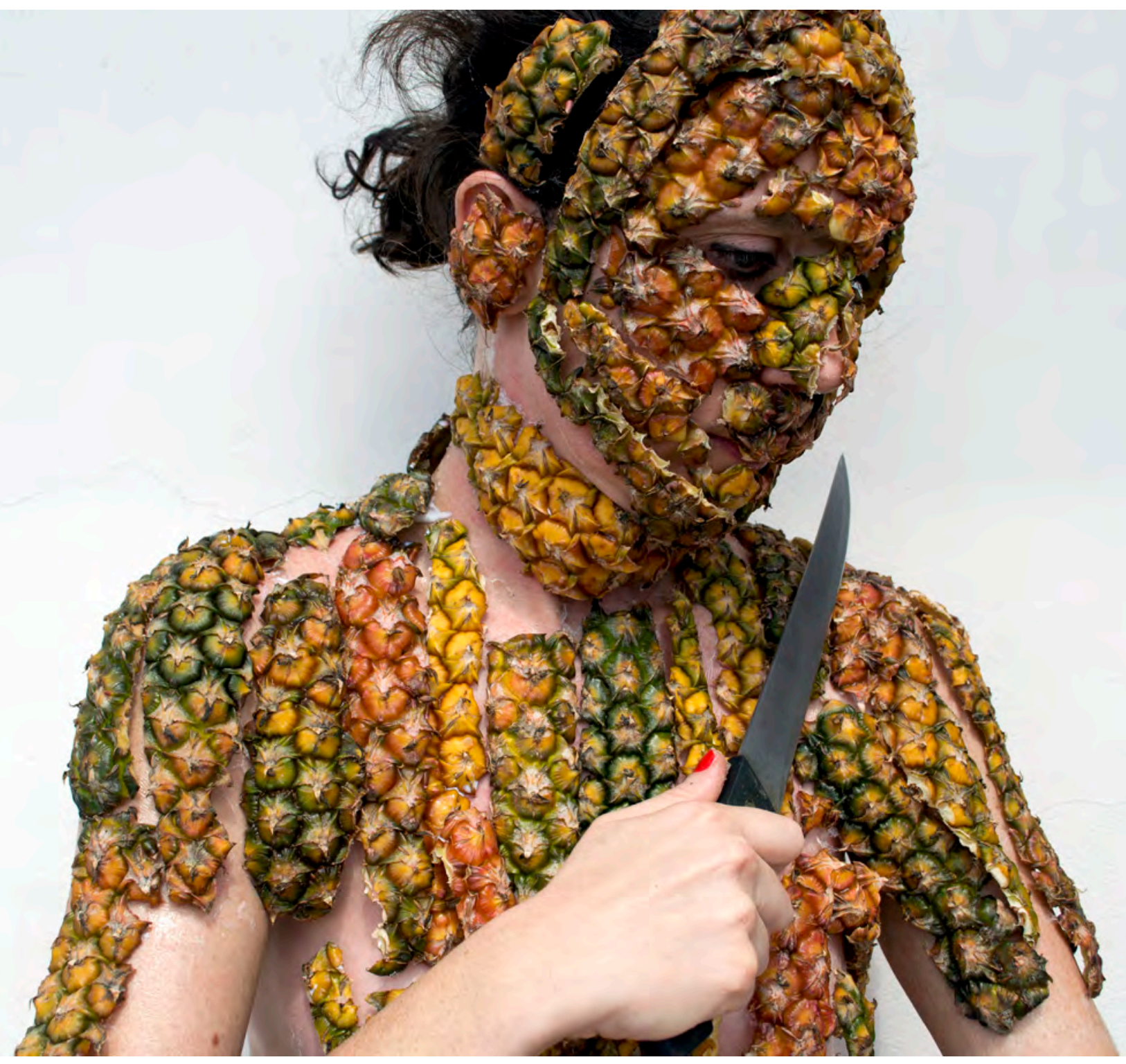




\subsection{Sem Título (ação para a câmera fotográfica. Série de 06 fotografias)}

Após a realização dos trabalhos "Sem Título" tanto em foto como em vídeo e videoinstalação, em que fiz a utilização de cascas de ovo, continuei a pesquisar sobre cascas, modificações do corpo, da pele e logo a seguir tive um insight ao ver um senhor vendendo e cortando abacaxis nas proximidades do metrô Carrão. Já tinha presenciado cenas como essas várias vezes, porém, nesse dia anotei no caderno de ideias que usaria em uma de minhas ações cascas de abacaxi em meu corpo. Não sabia se iriam aderir bem, que tipo de cola deveria usar e se causariam alguma alergia. Realizei diversos testes com as cascas. Observei que as cascas do abacaxi são mais pesadas e mais aquosas por manterem um pouco da fruta, dificultando a colagem no corpo. Assim, retirei ao máximo a parte mole e aquosa da fruta da casca e as expus no sol. Desta forma, consegui a aderência apenas utilizando cola branca. A cola branca, assim como no trabalho das cascas de ovo, passava a sensação de pele e esse procedimento foi utilizado nas performances.

Iniciei a série fotográfica em 2015. Resolvi retirar as cascas com uma faca razoavelmente grande, como via os feirantes e o senhor que comentei estar vendendo e cortando abacaxis.

Este trabalho, assim como o trabalho "Sem Título", em que uso casca de ovo, possui versões (ou desdobramentos) tanto como ação para a câmera fotográfica como para a câmera de vídeo. Para a câmera fotográfica realizei várias fotos da sequência de retirar as cascas, porém selecionei seis fotos para o trabalho final. Abaixo apresento uma foto do processo e na página seguinte a obra finalizada.

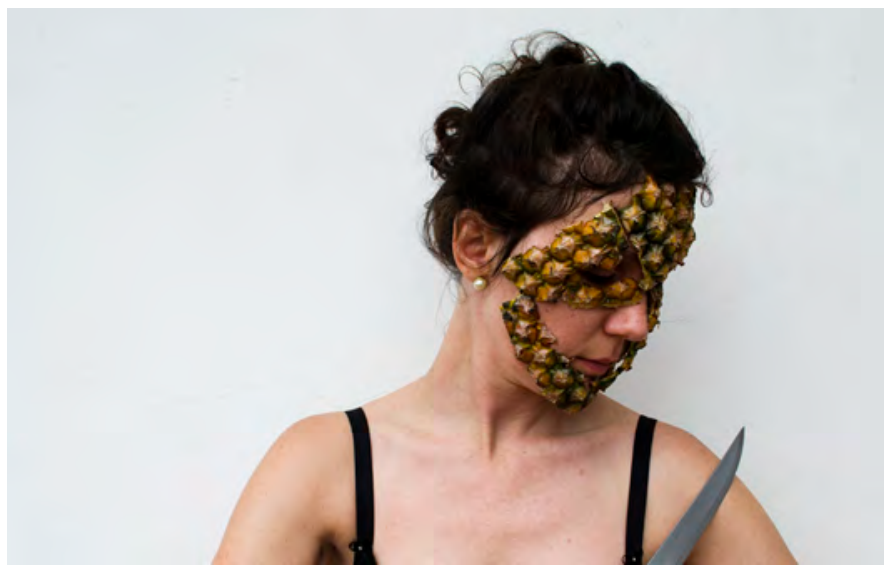

Creio que muitos de meus trabalhos (como já comentei na introdução desta tese) sejam feitos dessa forma, pelas traduções entre diferentes meios e formatos, não por não achar uma forma adequada, mas sim pelo fato de terem afinidades com a temática que estudo e me interesso: mudanças de estado e identidades provisórias. 

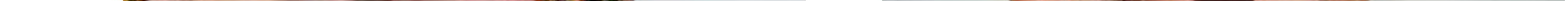


\section{4 “Sem Título" Versão 1 e versão 2 (vídeos)}

Em meu processo criativo a passagem de meios, formas e "versões" é significativa para as sensações dos trabalhos. A seguir comentarei sobre os desdobramentos das fotos anteriores, que geraram dois vídeos (versão 1 e versão 2)

Realizei estas duas versões no ano de 2016 da ação performática para câmera de vídeo. Em uma delas (versão 1) aderi poucas cascas de abacaxi em meu corpo e mais cascas na (versão 2). Realizei em ambas a ação de retirar as cascas de abacaxi de meu corpo. Realizei duas vezes a ação para a câmera de vídeo. Com uma faca, com gestos de um violinista e ao som de uma música de Johann Sebastian Bach, realizo esta mesma ação nos dois vídeos.

Um acaso interessante aconteceu durante o processo da versão 1 de "Sem título". Quando estava realizando o vídeo, uns mosquitos passaram a rondar meu corpo,

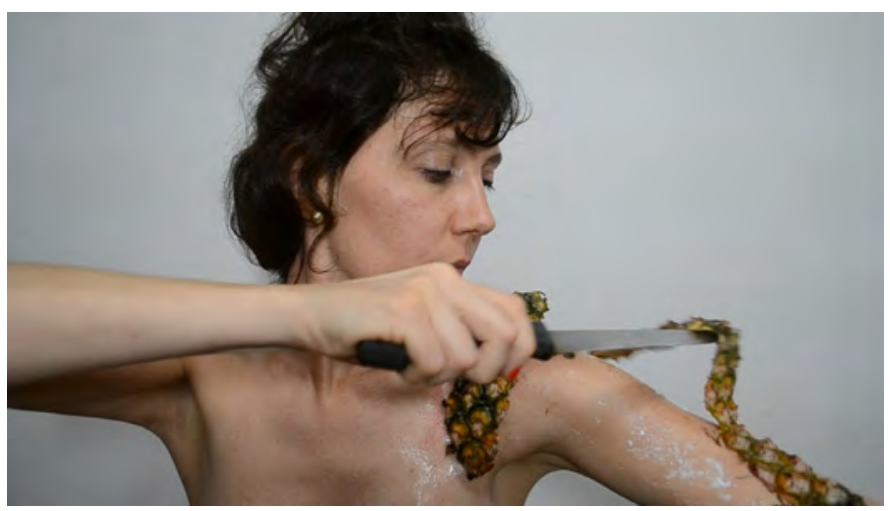

Versão 1 - Duração 01'39", ano 2016, Câmera: Mercedes Espírito https://www. youtube. com/watch? $v=Q A m z Y j 8 C 014 \&$ feature=youtu. be atraídos pelas cascas de abacaxi fixadas nele. No vídeo eles aparecem brevemente, porém é difícil vê-los por serem pequenos e em quantidade reduzida. Este fato gerou um insight para outro trabalho, que está ainda como nota e o apresento rapidamente no final desta tese. Para este novo trabalho farei a ação de ficar quase imóvel diante da câmera com cascas de banana mais maduras em meu corpo de forma a atrair mais "moscasda-fruta", ou Drosophila melanogaster. Elas farão parte da ação juntamente com meu corpo. Fato curioso é que após esse acaso pesquisei sobre essas mosquinhas e descobri que elas são importantes para a investigação do ser humano. Por terem seu ciclo de vida muito curto podem ser estudadas de geração em geração e assim é possível investigar os efeitos do tempo a partir delas e estender a investigação aos seres humanos. São muito utilizadas nos estudos sobre genética consistindo em organismos modelo na biologia.

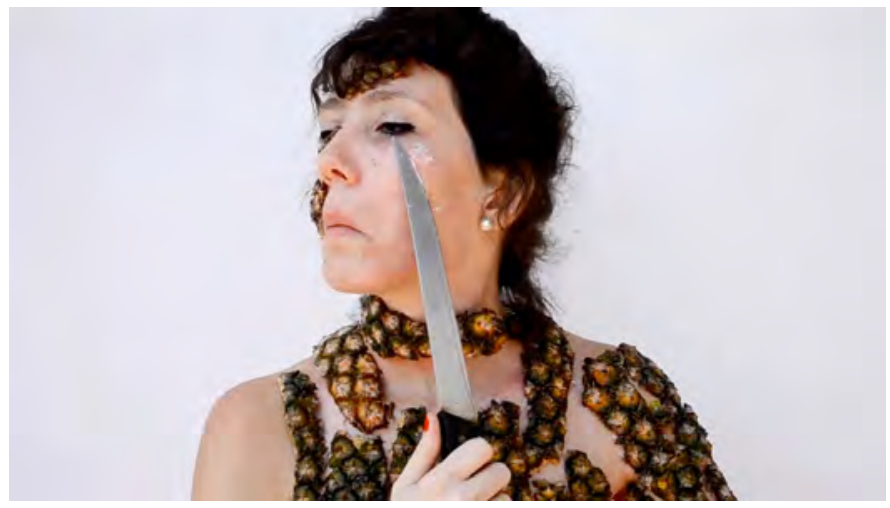

Versão 2 - Duração 03'40", ano 2016, Câmera: Mercedes Espírito https://www.youtube. com/watch?v=30Dvo7AhyOo 
Em 1933, Thomas Hunt Morgan ganhou um prêmio Nobel por estudar como a Drosophila recebia de herança uma mutação genética que deixava seus olhos brancos, e não vermelhos. A pesquisa de Morgan levou à teoria sobre genes produzidos pelo DNA serem carregados por cromossomos, que eram transmitidos por gerações. A descoberta preparou o terreno para a genética moderna e o estudo da teoria cromossômica da herança [...]Conhecimento atual sobre como nos desenvolvemos, nosso comportamento, envelhecimento e evolução, todos são construídos sobre a base dessas pesquisas com moscas-da-fruta. (retirado de: https://www.bbc. com/portuguese/vert-earth-37014344, consultado em 25/03/2019)

Tais informações foram importantes para querer dar continuidade ao novo trabalho, já que essas moscas contribuem para melhor conhecimento dos humanos, seja na genética, no envelhecimento e, principalmente, no comportamento. Acho interessante fazer a ação com essas moscas a rodear-me já que, pelos estudos, somos semelhantes e a partir delas podemos nos conhecer melhor. Os primeiros estudos que estou realizando aparecem ao final desta tese como um trabalho em andamento.

Após estas considerações dou continuidade ao texto dos trabalhos concluídos e que estão neste capítulo. A construção de um rosto/máscara (tanto nos trabalhos com cascas de ovo como nos de cascas de abacaxi ) utilizando uma nova pele teve a intenção de simbolizar renovação, mudança e apresentação de passagem de estados psíquicos, trocas afetivas na relação entre externo e interno através da pele. A pele está sempre em processo de renovação. Ela escama. Essa característica interessava aos trabalhos. A pele comunica estados, sensações, marcas do tempo e é, segundo Sergio Gomes da Silva, em seu texto "As modificações corporais na sociedade contemporânea", objeto de estudo de várias especialidades como:

[...] médicos dermatologistas, homeopatas, esteticistas [...] escritores, poetas, músicos que veem no 'corpo à flor da pele' toda a dimensão da nossa subjetividade traduzindo sentimentos, emoções e sensações em palavras [...] A pele ainda é o lugar de investimento libidinal, lugar de sedução, reduto de prazer e dor, está submetida à recepção dos estímulos detectados pelo sistema nervoso central [...]Ela pode ainda comunicar, com poucos sinais, o estado de saúde, doença, bem ou malestar. Empalidecemos quando ficamos surpresos ou ante uma ameaça, ficamos ruborizados quando nos sentimos envergonhados, nos arrepiamos quando sentimos frio, medo ou estamos excitados. Enfim, a pele se comunica com o mundo, e este também se comunica com o sujeito através da superfície da pele.

(2011, p 254-255).

A pele comunica visualmente o estado de saúde do ser, das suas emoções e assim se dá o seu diálogo com o mundo. A pele com cascas de ovo ou com abacaxi remete: ao simbólico, à impressão visual de afecções (enfermidades) para além de seu caráter de armadura, de ser monstruoso, de corpo híbrido entre humano e animal. As afecções da pele também estão relacionadas a crises emocionais e com o stress (ANZIEU, (1989). Caminhei em direções aparentemente opostas nos 
dois trabalhos (em um deles, o do abacaxi, retiro as cascas; no outro, o do ovo, as adiciono), mas no final elas apontam para o mesmo sentido: de libertar-se das amarras sociais e regras do corpo com a intenção de restabelecer o corpo e deixá-lo sentir, sem armaduras. É como retornar à pele fina, sensível e existencial que dialoga com o externo e com o devir, quando retiro as cascas grossas de abacaxi que impedem ou diminuem impactos, sensações e trocas entre interno e externo. O trabalho em que uso cascas de ovo aponta para esse caminho do devir, de renovação, renascimento através do uso simbólico do elemento ovo. Algo que nasce ou que indica nascimento terá sempre uma pele que sente o mundo, seus devires como novidade e singularidade.

Criamos armaduras, modelos funcionais para o nosso corpo, e acabamos por afastar os sentires e contatos com o mundo através de remédios, psicotrópicos e potencializadores de ânimo, buscando adquirir leveza e alterações de humores. Peter Paul Pelbart, em "Vida Capital" (2003), comenta, baseado em escritos de Nietzsche, de David Lapoujade, Foucault e Deleuze, que o corpo não aguenta mais o adestramento, a disciplina, o sistema de martírio que o cristianismo e mais atualmente a medicina elaboraram para lidar com a dor, culpabilização e patologização do sofrimento, insensibilização, negação do corpo etc. E acrescenta: “Diante disso, seria preciso retomar o corpo naquilo que lhe é mais próprio, sua dor no encontro com a exterioridade, sua condição de corpo afetado pelas forças do mundo". (PELBART, 2003, p.45)

No trabalho da casca de ovo trabalhei com a parte simbólica do elemento ligada a renovação e nascimento e no de abacaxi pretendi ir mais para o lado de afecções, enfermidades da pele e também da simbologia ou expressão popular da dificuldade de 'descascar um abacaxi'. As afecções funcionam de certa forma como uma armadura, uma proteção criada pelos órgãos internos, pelo ser que sente rejeições a algo que incomoda, que faz mal ou que foi mal digerido após contatos e estranhamento com o ambiente externo. $\mathrm{O}$ corpo e a pele, principalmente, produzem essas marcas através do seu aspecto. "A interioridade do sujeito é um constante esforço de exterioridade, reduz-se a sua superfície." (LE BRETON, 2003, p 29)

A pele é o maior órgão do corpo, é um órgão tátil. Segundo o estudo de Ashley Montagu em "Tocar: o significado humano da pele" (1988), o toque é importante desde o útero materno até o fim da vida e esse toque está ligado ao crescimento e ao desenvolvimento físico e comportamental. As pesquisas apontadas por esse autor afirmam que negligenciar o toque em todas as etapas da vida acarreta doenças no sistema respiratório, físicas e psíquicas. O toque é fundamental para crescer e desenvolver-se socialmente por meio do contato.

O uso de cascas de abacaxi faz com que o toque tão fundamental como apontado pelo autor seja distanciado 
ou não sentido, funcionando como uma armadura do sentir. Nega o externo. Procura diminuir o impacto dos estímulos e assim não se entregar aos afetos, aos toques, intimidades, ao contato social.

Também trabalhei as cascas de abacaxi no sentido de transformar o corpo em um aprisionamento diante de tantas regras de beleza e modos de culto ao corpo, que fazem com que sintamos nosso corpo como monstruoso, preso, problemático e de difícil aceitação e convivência, como se tivéssemos de "descascar um abacaxi". Apresentar o corpo em sua pele fina com a retirada da casca grossa por meio de cortes, ora sutis ora mais agressivos, seria uma possibilidade de abrir esse corpo aos devires do mundo e assim apontar resistência, já que os corpos contemporâneos costumam protegerse dos sentires lançando mão de medicação, de psicotrópicos e de afastamentos afetivos e de toques, na busca do distanciamento entre os contatos físicos e diversos recursos para aliviar as sensações do corpo diante do mundo.

Creio que os trabalhos desenvolvidos apontam para esta direção: abrir-se ao contato com a pele fina e sensível, no caso da obra do abacaxi, e um ser novo (principalmente no trabalho com cascas de ovo) que está por vir com sua subjetividade e devir em potência. Essas imagens também contêm uma carga irônica.
A escolha de retirar as cascas acompanhada de música e a comparação com a postura de um violinista se deu por analogia já que os movimentos que fiz durante os estudos que realizei para a retirada das cascas indicavam isso. Durante o estudo e olhando a gravação do ato, percebi a analogia com tocar um instrumento (no caso o violino) e resolvi realizar o ato dessa forma. O próximo passo foi a escolha da música. Escolhi a música de Johann Sebastian Bach (Violin Partita no. 1, BWV 1002-2-Bach 2 - Double-2105-7009, em domínio público). Ouvi a música várias vezes e tentei durante a ação seguir seu ritmo durante os cortes.

Embora em diversos trabalhos apresente seres intocáveis, não acredito de fato que assim sejamos; acredito que se trata apenas de aparências. Agimos assim, como zumbis, por questões de ordem econômica, hábitos, repetições de atos e costumes e não porque somos e sentimos de fato dessa forma. 


\section{5 "Sem Título (03 fotografias)}
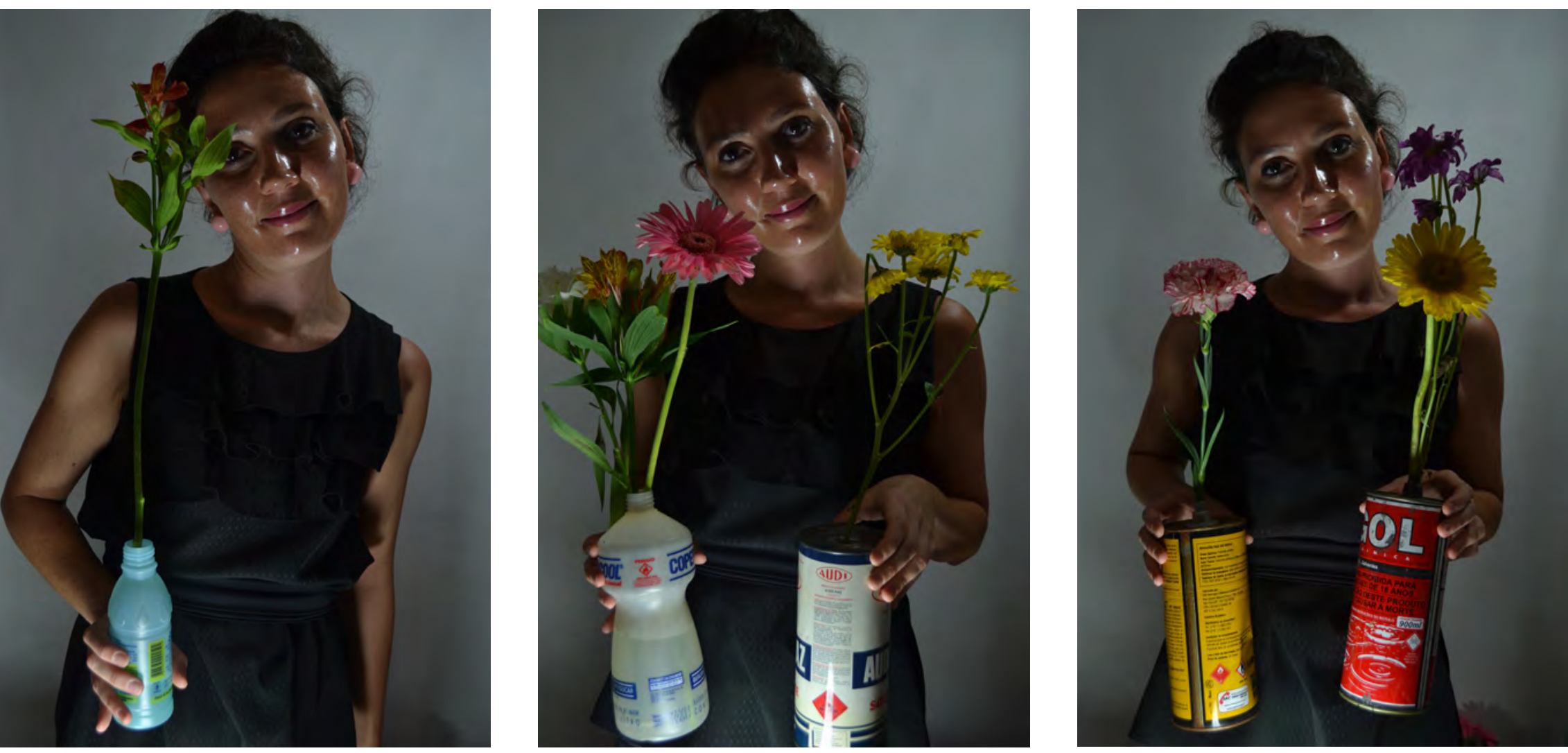

Vivane Vallades. Sem Título, Fotografia, 2016

Câmera: Mercedes Espírito 
Nesta série fotográfica realizo poses, gestos e iluminação semelhantes a fotografias de estúdio para books, mas insiro estranhamentos nesses elementos assim como em minha expressão do rosto plastificada e imóvel atrás de uma máscara plástica e na relação dos objetos que manipulo e com os quais componho a ação. Seguro em minhas mãos vasilhames com líquidos insalubres à vida das flores que estão contidas neles.

Congelo, através da fotografia, as flores em seu aspecto exuberante e vivo, assim como minha expressão petrificada, nas três imagens da série. Fiz diversos estudos e fotografias para chegar ao trabalho "final" com três fotos. Realizei teste de iluminação, de enquadramento e pose. Também fiz pesquisa sobre como petrificar a expressão. Fiz experimentos em um primeiro momento com máscaras feitas de água e gelatina em pó.
Entretanto, esses testes ainda não eram o que queria. Utilizando gelatina a máscara ficava muito visível e grosseira; queria algo mais sutil.

Passei a procurar outras máscaras e encontrei uma, plástica, vendida em casas de cosméticos que, ao ser aplicada na pele, formava uma película transparente e flexível. A expressão fica petrificada e mais fina e mais sutil pela transparência após a aplicação. Essa máscara foi a escolhida para a finalização do trabalho.

Refiz testes de enquadramento e iluminação com a nova máscara. Também utilizei flores artificiais das quais deixei a etiqueta de procedência e material. As flores artificiais também me interessavam, porém, para esse trabalho, as flores naturais iriam mais ao encontro do que pretendia, pois gostaria de criar uma metáfora para a vida com foco no convívio social e nas teatralizações cotidianas.
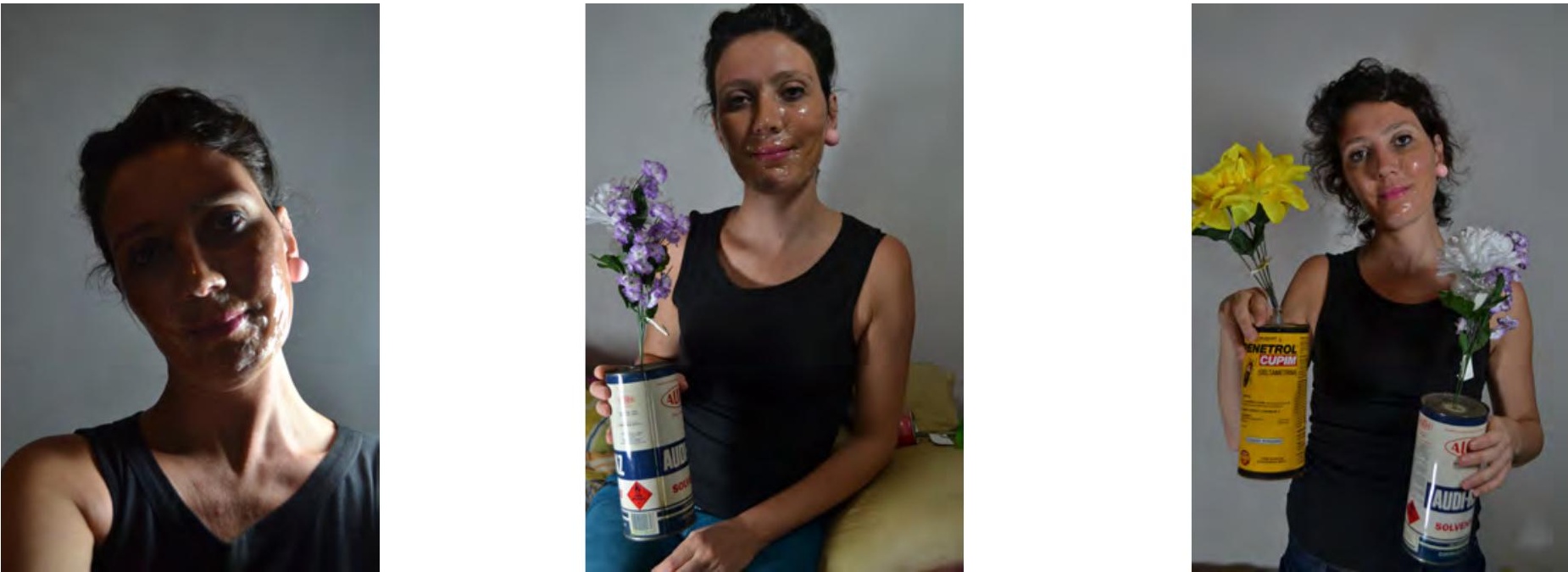
Nesse trabalho pretendi abordar as representações e encenações que fazemos para nos moldarmos às condições ditadas pela sociedade. A necessidade de máscaras e camuflagens do sentir para garantir a sobrevivência do homem. Embora esse trabalho possa apontar num primeiro olhar uma aparente aceitação e um ajuste cordial à vida cotidiana, ele causa um estranhamento. E é esse estranhamento que me leva a propor uma reflexão.

Vejo e sempre fico pensando se há outras maneiras de vida social ligadas ao modelo que o sistema econômico nos propõe. Por exemplo, passo sempre em lojas de calçados e lojas de roupas dos shoppings ou fora deles e observo os trabalhadores em pé durante 8 horas aproximadamente. Apesar desse desconforto corporal, os trabalhadores devem estar sempre com rostos alegres para atrair os clientes. Não é possível que esse corpo exausto fique indiferente e abstraia essa sensação para voltar-se ao atendimento cordial. Sei que é um trabalho e que no olhar geral é assim mesmo, mas essa situação realmente me incomoda e é um pouco disso que trato neste trabalho.

Recordo-me aqui do livro de Franz Kafka (18831924) "Metamorfose", (2012) no qual o autor trata da metamorfose, embora de forma mais exacerbada que em meus trabalhos, pois o personagem transforma-se totalmente, não tendo mais um corpo de fato como eu ainda mantenho. No conto, o personagem se transforma em um inseto. O ponto de interesse desse conto nesta tese é uma das possíveis leituras sobre a metamorfose de Kafka: o fato de a transformação/ metamorfose apontar para uma mudança, um estado de passagem em que o ser sendo outro não pode mais realizar suas tarefas cotidianas, apresentando assim uma ruptura com o cotidiano e com os contratos sociais, propondo questões sobre a convivência com o que é diferente e com o que não tem serventia social. No conto, quando o personagem encontra-se metamorfoseado e assim não exerce mais sua função de assegurador e provedor da família, não sendo mais útil, deve ficar enclausurado num quarto com distanciamento afetivo até culminar em sua morte. Assim, mesmo o personagem não sabendo o motivo de sua metamorfose ou não nos revelando de fato como ela aconteceu, ele acaba por dar um fim às máscaras e teatralizações cotidianas. Perde função e cargos a partir da perda da forma e da consequente metamorfose de seu corpo. O novo corpo do personagem exige novos devires, pois ele deve agora sentir de outra maneira, sentir novamente desde os mais simples movimentos de seu corpo, observar como fazê-los com sua nova configuração. É um corpo devir.

Todos os trabalhos abordados neste capítulo tratam de peles artificiais que pretendem questionar os modelos e aprisionamentos inseridos nos corpos contemporâneos, mas que apresentam um desejo de transformação e novas possibilidades de sentir sem fechar-se ao externo. Mesmo o trabalho com máscara plástica, 
que parece ser apenas uma repetição da teatralização cotidiana para nos adaptarmos às necessidades de cada local ou situação, procura mostrar pelo estranhamento

do aspecto artificial da expressão que a aparência é diferente do sentir. 
Capítulo 4

O corpo em palavras e falas 
Este meu corpo. Este corpo que não é o meu. Este corpo que é, no entanto, o meu. Este corpo estrangeiro. Minha única pátria. Minha morada. Este corpo a reconquistar. (HYVRARD, J. La meurtritude apud Le Breton, 2009, p. 15)

\subsection{Sem Título (Vídeo, 2015)}

Este trabalho surgiu no ano de 2015 e, como alguns de meus trabalhos, o insight se deu através da observação de um acaso. Eu estava passando na sala de minha casa e minha sobrinha apertava uma boneca que emitia frases. Aquilo me chamou muito a atenção. Fiquei pensando no conteúdo das frases, nas perguntas, sentenças e sentimentos que a maioria das bonecas desse tipo apresenta. Pensei também no formato, modelo de corpo da boneca e com mais ênfase sobre o que ela falava.

Passados alguns dias, minha sobrinha quebrou o brinquedo, mas o dispositivo que emitia as frases, embora solto do corpo da boneca, ainda funcionava. Imediatamente tive o desejo de inserir esse dispositivo em meu corpo para manuseá-lo de forma a apresentarme com falas que ficariam artificiais e mecânicas por esse procedimento. Seriam falas mecanizadas proferidas como se fosse sem pensar, respostas e sentimentos prontos ou como um computador que busca uma informação assim que acessado. O conteúdo das frases me interessava tanto quanto o mecanismo.

Realizei uma ação na qual eu ficava sentada quase sem movimentos diante de uma câmera de vídeo inserida num tripé. Com enquadramento fixo, deixei a câmera imóvel e tentei manter meu rosto com a mesma expressão o tempo todo, independentemente da frase que fosse proferida assim que apertasse o dispositivo de fala da boneca que fixei em meu peito. Algumas das frases proferidas são: "Que dia lindo!", “Amo tanto você", "Você gostou da minha roupa?', “Que legal!" etc.

Queria tudo muito simples e assim optei por um fundo branco e roupa preta de forma a deixar o dispositivo, a ação de tocá- lo e a expressão de meu rosto em evidência. Achei interessante apropriar-me e fazer uso de um fragmento de um objeto cultural que foi confeccionado e baseado em características antropomórficas e em nossos hábitos, como uma miniatura humana ${ }^{1}$. Mesmo a boneca não estando visível na ação que realizo e apresento em vídeo, as falas remetem a ela.

Em alguns momentos do vídeo aperto o dispositivo ainda no meio de uma frase proferida para que esta seja substituída pela próxima fala de forma a sugerir que estou buscando uma frase mais apropriada para um certo momento ou situação, como se eu estivesse em alguma atuação teatral social. Na vida cotidiana, de

1 Há toda uma problemática sobre que tipo de miniatura humana é mais confeccionado, isto é, qual padrão de beleza é mais difundido e assim mais aceito como a cor da pele mais utilizada, e estereótipos de corpo magro, esbelto etc. que são comuns em confecções de brinquedo, principalmente nas bonecas. Mesmo retirando o corpo da boneca de cena na ação para a câmera, não poderia deixar desapercebida essa problemática que está relacionada também ao trabalho que desenvolvo de modo geral, repetição de comportamentos, do aceito e difundido socialmente e o valor que é atribuído a essas questões em cada época. 
modo geral, teatralizamos de acordo com uma situação específica. Segundo Goffman em "A representação do eu na vida cotidiana" (2005), assim que nos encontramos face a face com outro ser começamos a teatralização, isto é, nos tornamos como atores no palco de um teatro tradicional. O autor desenvolve o estudo da representação baseando-se na metáfora da ação teatral para analisar interações sociais. O modo de nossa "teatralização", segundo ele, vai depender do local, da situação, de características que observamos, como a aparência, o modo de fala desse outro ser com que nos deparamos e isso é mais intenso se não conhecemos anteriormente o sujeito.

Nossos comportamentos, hábitos e modos de sentir são socialmente e culturalmente construídos por meio do contato com o outro que nos é espelho e com a cultura do local em que nascemos ou estamos inseridos, por isso é possível desenvolver e repetir um repertório de ações, gestos, respostas etc. mais adequadas para determinada situação. As possibilidades/potências do corpo (modos de pensar, agir, sentir e se expressar) são várias, porém, o convívio e a maneira de nos comportarmos e sentirmos são construídos na cultura e nas relações sociais. Isto não quer dizer que sejamos robôs. Temos nossas singularidades e histórias pessoais diante dos fatos e acontecimentos, mas podemos contar com um leque disponível e modelado de comportamentos aceitos socialmente. David Le Breton, em "As paixões ordinárias: antropologia das emoções" (2009), faz um estudo interessante sobre o comportamento, as paixões e os sentimentos e traz como exemplo as crianças criadas por animais, para tentar entender como se dá de fato a construção social e cultural para o corpo, comportamentos e sentimentos. Algumas crianças que foram abandonadas ou de certa forma foram parar em florestas (devido a guerras, pestes ou cuja família vivia perto), salvo as que foram devoradas por animais, acabaram sendo cuidadas por eles, como é o caso das crianças criadas por lobos. Essas crianças modelaram seu comportamento com base na espécie e assim imitavam a respiração ofegante e o bocejar dos lobos. Para correr apoiavam-se sobre as mãos e os pés, usavam a língua para beber líquidos, caçavam galinhas, mostravam os dentes quando alguém se aproximava e também desenvolveram maxilares mais proeminentes, dentes compridos e cortantes etc. Com esses exemplos pode-se observar as possibilidades e maleabilidades do comportamento e do corpo humanos.

Um fato muito interessante é que os sentimentos também são modelados. Ainda sobre essas crianças, o autor aponta que elas nunca riam, e tinham apenas algumas emoções elementares como a raiva e a cólera. Algumas crianças-lobos foram retiradas da selva e retornaram para a sociedade. Algumas morreram rapidamente e outras conseguiram modelar seu comportamento razoavelmente no novo meio, mas nunca apagaram sua história corporal e comportamental passada. 
Ainda do mesmo autor, há exemplos de marinheiros e náufragos abandonados que ficaram muito tempo sem o uso da palavra e do contato humano e acabaram adquirindo comportamentos mais "selvagens", semelhantes aos dos animais com que conviviam ou que tinham que perseguir para o abate para sua sobrevivência. Aprenderam a correr bem mais rápido do que o normal quando a presa assim o exigia.

Podemos concluir, então, que os comportamentos e sentimentos são construídos no decorrer da vida e o modelo de construção está relacionado a uma época, local, tipo, necessidades e valores de uma sociedade e, portanto, seguimos também modelos de exibição social. E quando saímos desse modelo sabemos que há algo "errado". Mesmo que a comunicação por vozes, gestos não seja cem por cento segura, podendo gerar ruídos em sua leitura, quase sempre conseguimos uma leitura aproximada do que está acontecendo por conhecermos e estarmos inseridos nos modelos usuais.

Marcel Proust, em "Sodome et Gomorrhe", nos apresenta uma passagem sobre isso:

Ela estava conversando comigo, mas eu estava odiando o que ela dizia. Eu estava absorto na continuidade uniformemente banal com a qual meus sentimentos mudavam de minuto em minuto, passando do medo à ansiedade, da ansiedade à decepção completa. Contrastando com as palavras vagamente agradáveis que eu lhe dizia por obrigação, eu sentia meu rosto tão desgostoso que fingi sofrer de reumatismo para Ihe explicar a divergência entre a minha indiferença simulada e aquela expressão dolorosa. (apud LE BRETON, 2009, p.144)
Aqui Proust não conseguiu adequar a expressão facial a um modo favorável à situação, mas o fez de outro modo pela explicação, por meio de palavras, atribuindo a expressão contrariada que ele apresentava diante da conversa a um outro mal físico.

Neste trabalho procurei refletir um pouco em torno disto: comportamentos, gestos, falas e modelos construídos socialmente. Entretanto, se a teatralização na vida cotidiana deve ser sutil ou praticamente imperceptível para que de fato ocorra, neste trabalho ela fica em evidência. Torna-se mecânica pelo uso do dispositivo, da voz de boneca, e pela diferenciação entre a expressão de meu rosto e as falas, visto que não há alteração a cada sentença.

Apresento-me como um ciborgue, isto é, acoplo uma prótese em meu corpo. Embora o termo ciborgue carregue muitos conceitos, aqui eu o utilizo como meu corpo hibridizado a algum elemento (dispositivo) que possibilite uma extensão dele mesmo. Ainda que o dispositivo não seja uma prótese efetiva, feita por intervenção cirúrgica, ele funciona como uma extensão, uma prótese temporária. David Le Breton, em "Adeus ao corpo", define ciborgue como "organismo humano hibridado com a máquina tendo em vista o aumento da eficácia num determinado campo." (LE BRETON, 2003, p.20-21). O autor dá exemplos de ciborgue quando dirigimos nossos carros ou quando usamos escadas rolantes, por exemplo. E é nesse sentido que o conceito 
é utilizado aqui. Em "Sem Título" posso "falar" sem usar minha boca. E meus "pensamentos" e "falas" já estão armazenados no dispositivo.

Esse acoplamento de uma prótese com meu corpo pretende gerar diversas leituras e aqui não pretendo enfocá-las ou fechar as possíveis leituras, porém há questões que perpassam o trabalho: Seremos como robôs? Os poderes farão uso de equipamentos semelhantes em nosso corpo para sermos mais mecânicos e assim mais produtivos? Os dispositivos acoplados com o corpo serão extensões de raciocínio e modos de sentir? O corpo híbrido pode facilitar modos assegurados de trocas sociais e interpessoais? O que se diz é diferente do que se pensa e sente? Estamos sentindo mais ou menos? Somos seres fortes ou frágeis? Ato de resistência ou passividade?

David Lapoujade levanta uma questão que faz parte do interesse desta pesquisa e a comenta: Nosso corpo é um corpo que não aguenta mais? Segundo ele, em seu texto "O corpo que não aguenta mais" (2002), o corpo não aguenta tudo aquilo a que o submetemos do exterior, como o adestramento e a disciplina, mas também aquilo a que se submete de dentro, isto é, as mesmas formas externas que passam para dentro e acabam por parecerem "naturais".

Esses corpos que não aguentam mais são apresentados de diversas formas no campo das artes: retorcidos, magros, adormecidos, esticados. David Lapoujade faz essa constatação e aponta também semelhanças entre nós e os personagens de Beckett:

Somos como personagens de Beckett, para os quais já é difícil andar de bicicleta, depois, difícil de andar, depois, difícil de simplesmente se arrastar, e depois ainda, de permanecer sentado. Como não se mexer, ou então, como se mexer só um pouquinho para não ter, se possível, que mexer durante um longo tempo? É, sem dúvida, o problema central dos personagens de Beckett, uma das grandes obras sobre os movimentos dos corpos, movimentos de si e entre os corpos. Mesmo nas situações cada vez mais elementares, que exigem cada vez menos esforço, o corpo não aguenta mais. Tudo se passa como se ele não pudesse mais agir, não pudesse mais responder ao ato da forma, como se o agente não tivesse mais controle sobre ele. Os corpos não se formam mais, mas cedem progressivamente a toda sorte de deformações. Eles não conseguem mais ficar em pé nem ser atléticos. Eles serpenteiam, se arrastam. Eles gritam, gemem, se agitam em todas as direções, mas não são mais agidos por atos ou formas. É como se tocássemos a própria definição do corpo: o corpo é aquele que não aguenta mais, aquele que não se ergue mais. (2002, p.82)

Essas relações entre forças externas e internas, que são também fruto das externas, são questões que perpassam estes trabalhos, como modelos a serem seguidos, comportamentos esperados, mecanização etc. Em meus trabalhos trato-os ora de maneira irônica, de resistência, ora parecendo aceitá-los tranquilamente.

Muitas obras de literatura também tratam desse não aguentar mais as formas externas atuando e modelando nossos modos de viver. Muitas vezes apresentam corpos 
fracos, em posições estranhas, fora do padrão esperado socialmente.

Franz Kafka (1883-1924) apresenta personagens desse tipo. No conto "O artista da fome", de 1922, um personagem pálido que mal para em pé, o seu jejuador, vive trabalhando (jejuando) mas abandonado (sem público interessado no seu trabalho) numa jaula no fundo de um circo, o único local que ainda lhe restou para fazer suas apresentações. Porém, nem com a decadência da sua profissão o artista da fome (o jejuador, e pode ser estendido aos artistas em geral) deixa de ser um artista da fome, pois esta é a única coisa que o define. Pela fala final do protagonista, quando Ihe perguntam que tipo de jejuador ele é, fica um pouco mais claro entender que ele não estava afinado com o que ocorre no mundo, então ele prefere não comer. "Nessa renúncia ao mundo pressentimos o signo de uma resistência." (PELBART, 2003, p. 43)

\section{Abaixo transcrevo o diálogo comentado:}

- Ainda está jejuando? - perguntou o inspetor. - Quando, em nome dos céus, pretende parar? - Perdoem-me todos - murmurou o artista. Somente o fiscal, que tinha o ouvido perto das grades, conseguiu entendê-lo.

- Claro que o perdoamos - respondeu, batendo na testa, como a indicar aos empregados o estado mental do jejuador.

- Sempre desejei que admirassem minha resistência. - Claro que a admiramos - disse o fiscal, amavelmente.

- Mas não deviam admirar.

- Está certo, não admiramos, então, mas por que diz isto?
- Porque tenho que jejuar, não posso evitá-lo.

- Que tipo você é! - exclamou o inspetor

- Por que não pode evitá-lo?

- Porque não consegui encontrar comida a meu gosto - respondeu o artista, erguendo um pouco a cabeça e falando junto ao ouvido do outro, para que não se perdesse uma sílaba. - Se a tivesse encontrado, creia que não teria feito nada disto e me empanturraria como o senhor ou qualquer outro. (KAFKA, 2002/2003, p. 9-10).

Ainda de Kafka há também "Metamorfose", na qual através do seu corpo-inseto o protagonista se priva do trabalho, de ser o provedor e assim se afasta do que lhe oprime. Mesmo que por exclusão social, consegue sair da forma tradicional de vida, ligada ao trabalho e a sua vida de provedor de família.

Lembro-me também do conto de Herman Melville "Bartleby, o escrivão: uma história de Wall Street" (2005) no qual o personagem possui algumas características: é magro, cadavérico, olhos cinzentos, parados e opacos. A história gira em torno de Bartleby e sobre o comportamento que ele passa a adquirir logo após ter sido contratado como escrivão por seu chefe, que é o narrador do conto. A frase "I would prefer not" (tradução possivelmente mais aproximada do sentido do conto: Preferiria não) passa a ser repetida assim que seu chefe lhe pede para que exerça a sua função. Profere-a também ao ser despedido e ao ser despejado até que é preso e morre preferindo não se alimentar. Este conto possui algumas semelhanças com o meu 
trabalho "Sem Título", abordado neste capítulo: a forma repetitiva de o personagem proferir a sentença "I would prefer not" como se tivesse um botão que disparasse a frase. Embora diferentemente de meu trabalho em que profiro várias frases e repito apenas algumas e de forma inexpressiva, o escrivão repetia a mesma frase com tonalidades afetivas diferentes. Às vezes a proferia em tom agudo, depois de forma respeitosa e lentamente; outra vez, de forma soturna, como é apontado na narrativa do conto. Outro ponto de semelhança é o comportamento mecânico que o escrivão tem durante o trabalho, antes de passar a proferir a sentença. Segundo o narrador, Bartleby era uma figura impassível e, embora trabalhasse com rigor, fazia-o mecanicamente, sem nenhuma alegria, semelhantemente à expressão imutável de meu rosto enquanto as falas são ditas mecanicamente. Para além dessas características, o conto traz questões que são suscitadas nesse texto, como a teatralização da vida cotidiana e rompimentos com ela (essa é uma das variadas e possíveis leituras do conto). O personagem escrivão e também o narrador (seu chefe) rompem com a estrutura que é esperada na relação entre funcionário e empregador quando Bartebly passa a repetir a sua sentença diante das ordens de seu chefe, mostrando assim seu descontentamento como empregado, rompendo o modelo social e trabalhístico. Em contrapartida, o chefe posterga muito para mandar embora esse empregado. Coisa que não é comum nos moldes empresariais.
Esse conto é interessante por mostrar que a renúncia ao mundo pode ser um signo de resistência. Na leitura de Juliano Pessanha via Peter Pellbart personagens de literatura e das artes que apresentem e precisem de "imobilidade, esvaziamento, palidez, no limite do corpo morto" talvez o façam "para dar passagem a outras forças que um corpo 'blindado' não permitiria". (PESSANHA ${ }^{2}$ apud PELBART, 2003, p. 44).

As possibilidades do corpo, como apontado no decorrer deste texto, são diversas e repensar essas possibilidades, ainda mais em um contexto onde o corpo pode ser reformulado mais facilmente diante de tantas técnicas, e de todas as amostras que já tivemos sejam elas da vida cotidiana, das ciências da literatura etc. poderia ser uma forma de repensar e construir outros modos de vida. É importante percebermos a mecanização dos corpos a que estamos submetidos para poder buscar formas de subvertê-la.

2 PESSANHA, Juliano. Certezas do agora. São Paulo, Ateliê, 2002 


\subsection{Transporto sentimentos}

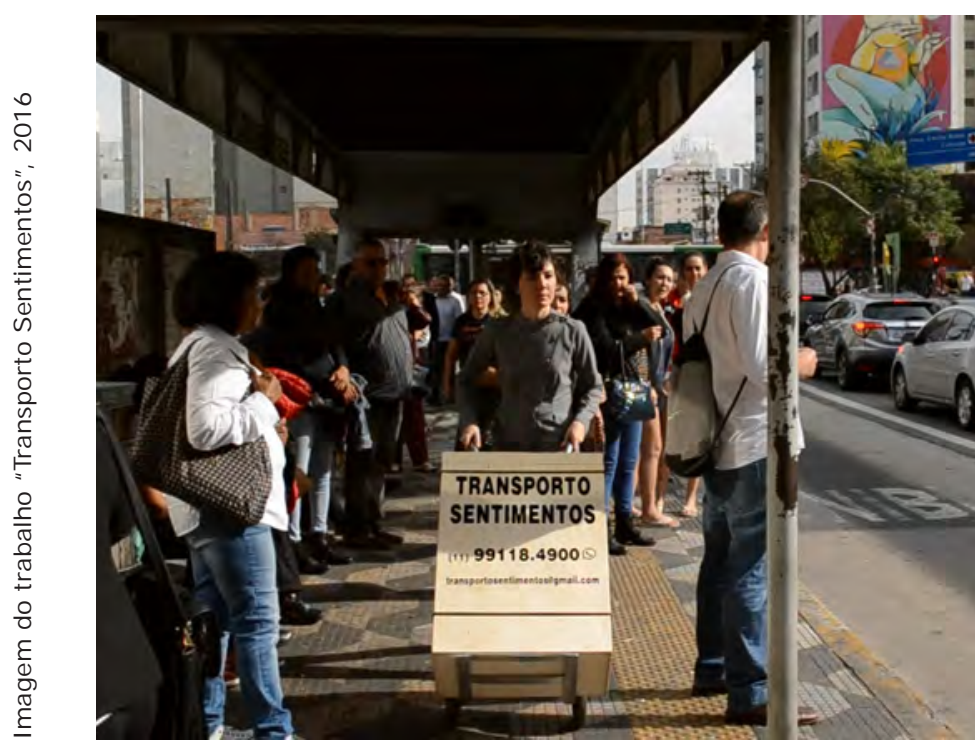

O conceito da obra "Transporto sentimentos" surgiu por volta do final do ano de 2015. Já estava realizando a obra "Sem Título", composta por frases inseridas no Facebook, que será comentada mais à frente nesta tese. Faço menção a essa obra porque foi a primeira em que passei a usar palavras/frases em meus trabalhos. Creio que "Transporto sentimentos" seja uma extensão desse processo e procedimento artísticos, tanto pelo uso de palavras como pela inserção do trabalho em âmbito social. O trabalho das frases se insere no contexto social do Facebook de forma pública e "Transporto sentimentos", como detalharei mais a frente, no espaço público: pelas ruas da cidade e pela praia. Esta foi a primeira ação artística que fiz corporalmente no âmbito do espaço público.

Nessa época fazia uma disciplina no MAC USP no I birapuera e, uma vez, quando atravessava a passarela Ciccilo Matarazzo, vi um homem carregando diversas caixas que, pela quantidade, impossibilitavam a visão de seu corpo inteiro. Não sei ao certo o que ele carregava, mas eram caixas de papelão. Ele passou e fiquei parada na passarela pensando e tive a ideia de carregar caixas que lembrassem caixas de transporte de obras de arte ( mais comuns para quadros, esculturas etc.) e adicionar inscrições nelas. Como estava com o pensamento voltado à realização de frases que trabalhassem questões existenciais cotidianas, logo surgiu a vontade de escrever "transporto sentimentos". Continuei meu trajeto com esse pensamento na cabeça.

Um ou dois meses após esse "insight" (que era realizar a ação de carregar um carrinho de mão com uma caixa com a inscrição "Transporto sentimentos" por vários pontos da cidade de São Paulo e também por uma praia), fui viajar e passar o fim de ano na praia em São Sebastião. Lá realizei, com ajuda de Marcos Nobre e Regina Vallades, alguns esboços com vídeos e fotos de como seria fazer esse trabalho na praia e pelas ruas ao redor, pois a ideia de fazê-lo na cidade e nas praias já estava nítida. Tirei fotos e fiz vídeos curtos e aproveitei um dos carrinhos de praia para simular o carrinho de mão que usei na obra final. 

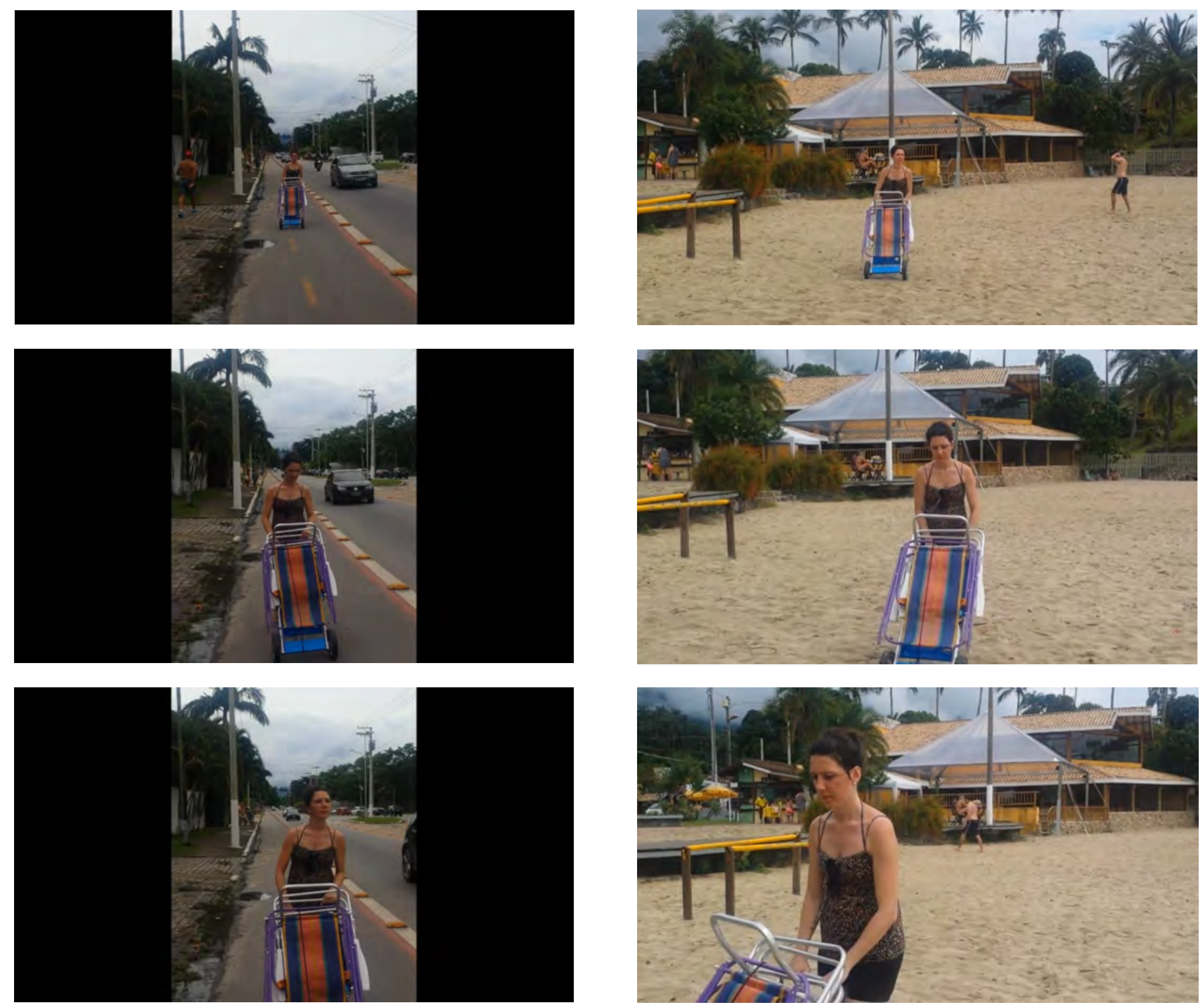
Fiz um vídeo curto com um carrinho semelhante ao que pretendia utilizar e caminhei saindo e entrando com o carrinho no enquadramento do vídeo como nas fotos anteriores. Planejei essa ação na qual saía e entrava no quadro do vídeo porque pretendia realizar uma videoinstalação com 03 telas em que o sair e entrar em cena estabelecessem uma relação de continuidade, de movimento entre as projeções, conectando espaços diferentes. Assim, em uma das telas eu estaria na praia e sairia de enquadramento para que na tela ao lado estivesse entrando em outro espaço (por exemplo, numa rua da cidade de São Paulo).

Posteriormente, quando voltei da praia para São Paulo, retomei esse material e fiz algumas edições de entrada e saída de quadro e entendi como poderia fazer a edição desse trabalho.

Com esse material em mãos, li que estava aberto o edital do LABMIS (Laboratório de Novas Mídias do Museu da Imagem e do Som) e resolvi me inscrever com "Transporto sentimentos" no ano de 2016. O material enviado foi o que tinha feito como esboço na praia e mais algumas fotos de imagens de carrinho de mão, juntamente com modelos de uniformes (roupas) para usar durante a ação.

Tinha em mente que usaria uma roupa específica, utilizaria caixas semelhantes às de transporte de obras de arte (já que estava fazendo arte, a caixa simbolizaria o transporte de sentimentos no âmbito das artes) e faria uma videoinstalação com 03 projeções de vídeos lado a lado. Também havia no projeto a informação de que eu iria adicionar um número de telefone com WhatsApp e e-mail nas caixas juntamente com a inscrição de "Transporto sentimentos".

Abaixo estão alguns dos estudos de objetos para o projeto:

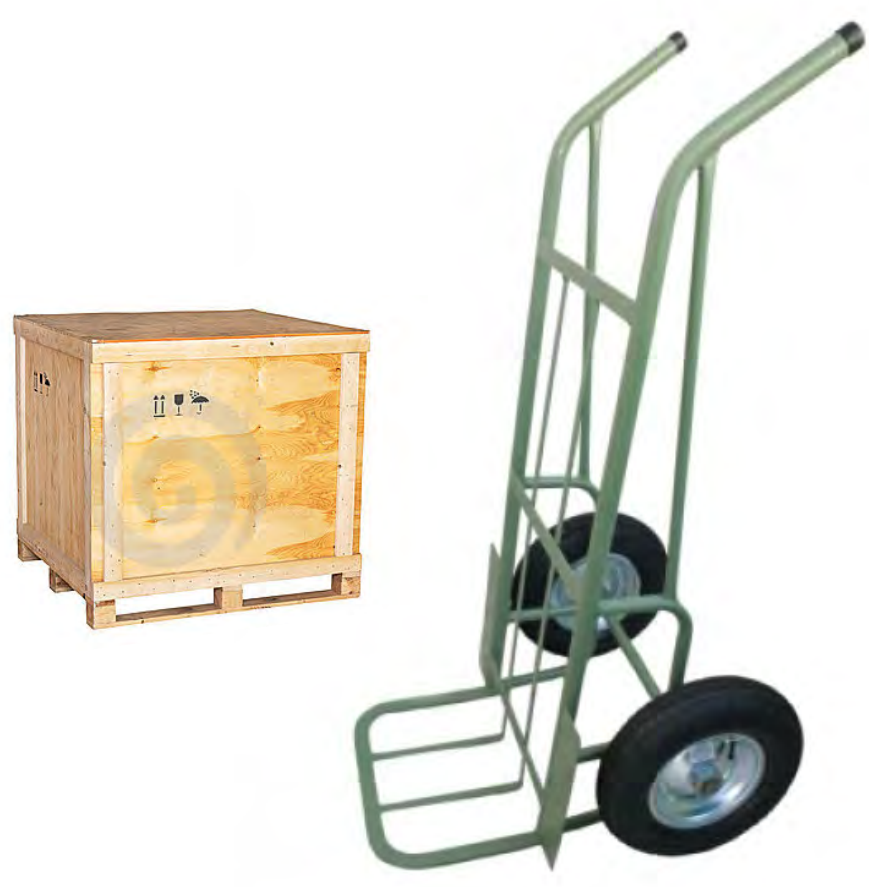


O projeto de "Transporto sentimentos" foi selecionado e passei a fazer mais esboços: para tamanho das caixas e quantidade delas, tamanho da letra das inscrições nelas contidas, cor do uniforme e número do telefone que usaria. Comprei um chip apenas para o trabalho de modo a facilitar a distinção entre as mensagens enviadas para o trabalho e minhas mensagens pessoais.

Com a expansão das formas de comunicação que propus para além do contato direto na rua durante a ação, através de e-mail e número de telefone com WhatsApp na caixa, abri possibilidades para uma comunicação posterior com os que pensassem no serviço e quisessem entrar em contato comigo. Poderia assim dar continuidade ao trabalho via telefone, WhatsApp ou por e-mail. Confeccionei também cartões com as mesmas informações contidas no oferecimento do serviço.

A Residência Artística no LABMIS teve duração de 03 meses (de maio a julho de 2016). A residência oferecia ajuda de custo, ajuda conceitual e orientação técnica, além de oferecer uma exposição final dos trabalhos produzidos. Após os estudos iniciais, passei a confeccionar alguns dos itens e comprar os outros prontos em lojas especializadas. Resolvi fazer uma única caixa de tamanho maior, quase do tamanho do carrinho de mão que havia comprado. As inscrições na caixa foram feitas com letras adesivadas. Confeccionei também um uniforme sob medida: um macacão cinza (neutro) que na parte posterior apresentava as mesmas informações contidas na caixa de modo a ficar visível o serviço quando estivesse de costas. Um uniforme nos moldes sociais gera mais segurança, comprometimento e autenticidade ao trabalho. Contratei Kadu Rossi, técnico de filmagem que me acompanhou durante toda a ação. Poderia contratar um amigo que soubesse filmar, porém, a escolha de trabalhar com desconhecidos também fez parte do processo, já que meus trabalhos procuram tecer fios nas tramas das relações sociais, convivência e acasos dessas relações.

Após escolher todos os elementos do trabalho, passei a realizar a ação na qual caminhava conduzindo um carrinho de mão pelas ruas do centro e de alguns bairros da cidade de São Paulo, assim como em uma praia (Guarujá) e dentro de alguns ônibus. Seguia caminhando pelas ruas até ser parada por algum transeunte que se interessasse e questionasse o serviço para logo em seguida retomar a caminhada. Também distribuía cartões com oferecimento do serviço aos que me parassem durante a ação.

Foram 04 dias de filmagem. Durante esse período passei por vários locais. Caminhei pelos arredores do Jardim Europa, pela Sé, Praça João Mendes, República, Viaduto do Chá, Luz, Paulista, por uma praia no Guarujá e dentro de ônibus. 

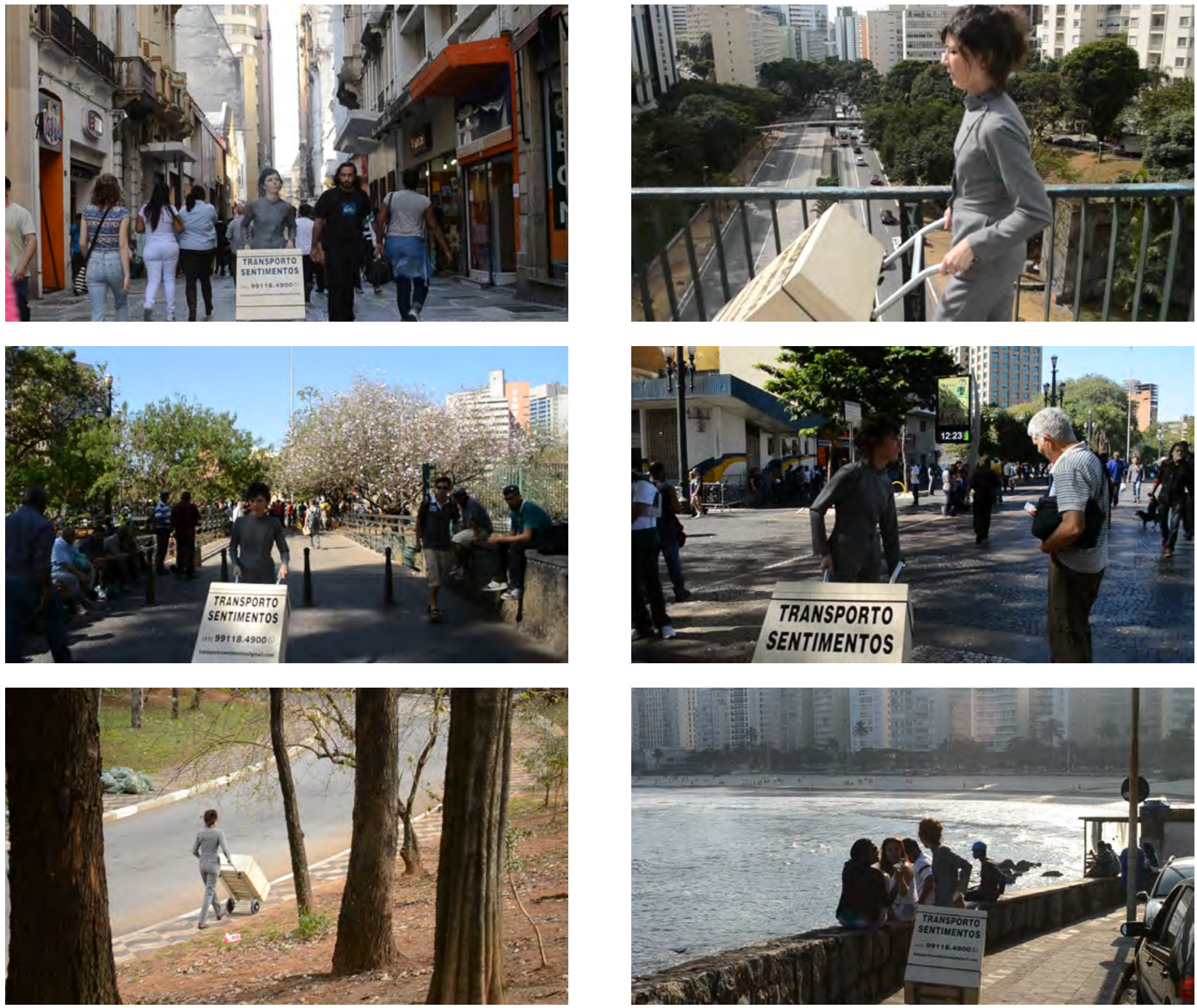


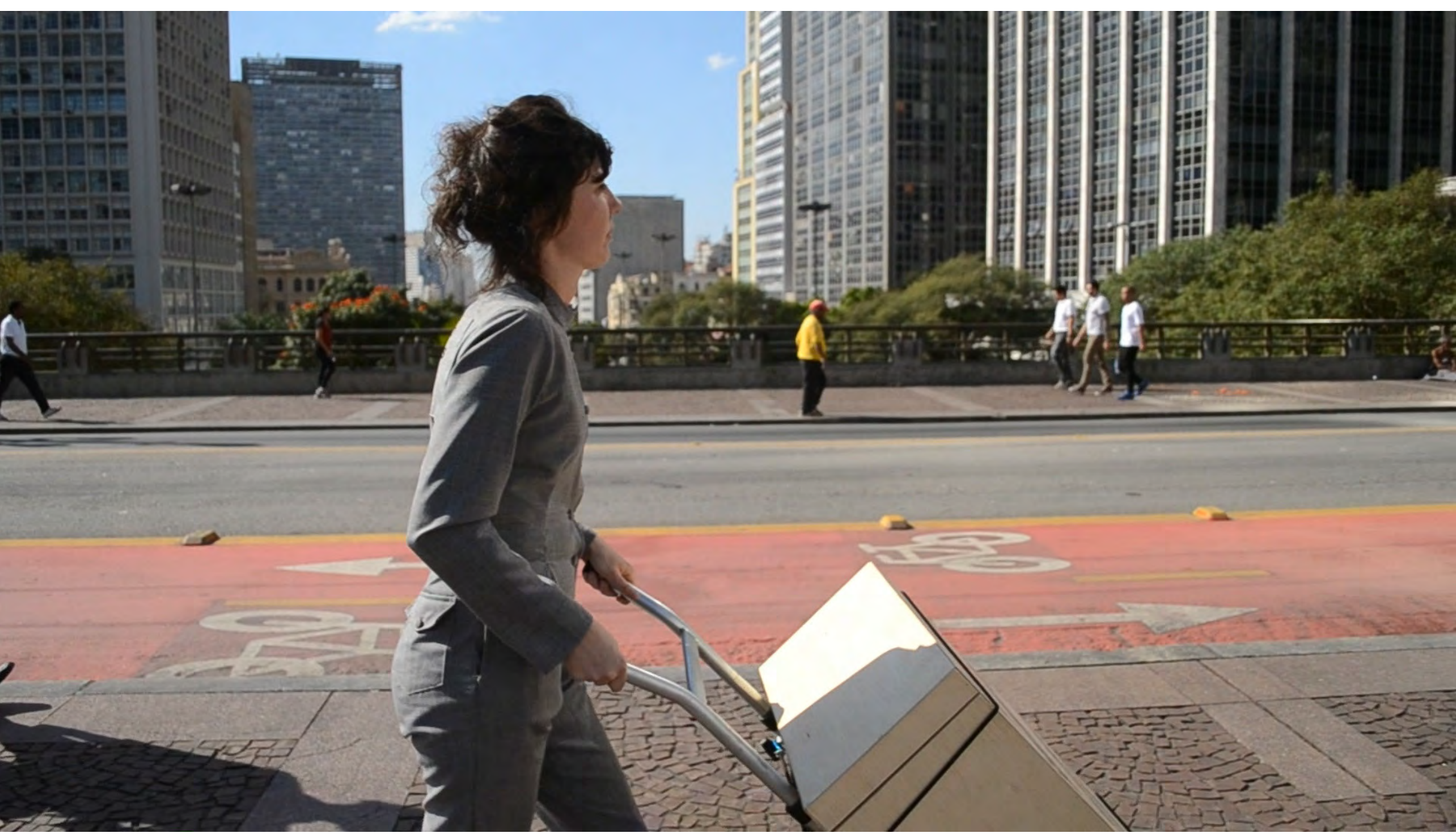

Viviane Vallades. Frames da videoinstalação "Transporto Sentimentos", 2016. Câmera: Kadu Rossi Link do vídeo: https://www.youtube.com/watch?v=BI6cSd6Bqps 
Após os dias de ação e de captação das imagens, parti para o trabalho de edição dos vídeos para tripla projeção. Fiz tudo num único arquivo pensando na relação entre as imagens nas três telas que seriam exibidas lado a lado. Em alguns momentos da videoinstalação encontram-se frames pretos em algumas das telas, ficando ora um vídeo projetado, ora dois, ora três vídeos projetados simultaneamente.
A exibição da obra ocorreu em 2017 com o formato de videoinstalação em tripla projeção. Realizei edições para que os vídeos captados em espaços e tempos diferentes fossem exibidos simultaneamente como a imagem abaixo. Um vídeo da ação realizada na praia, por exemplo, é exibido ao lado do vídeo da ação no Viaduto do Chá e no Jardim Europa. Para a projeção no MIS deixei os três vídeos em separado e projetados simultaneamente na parede de forma a ficar na ordem da edição que tinha realizado.

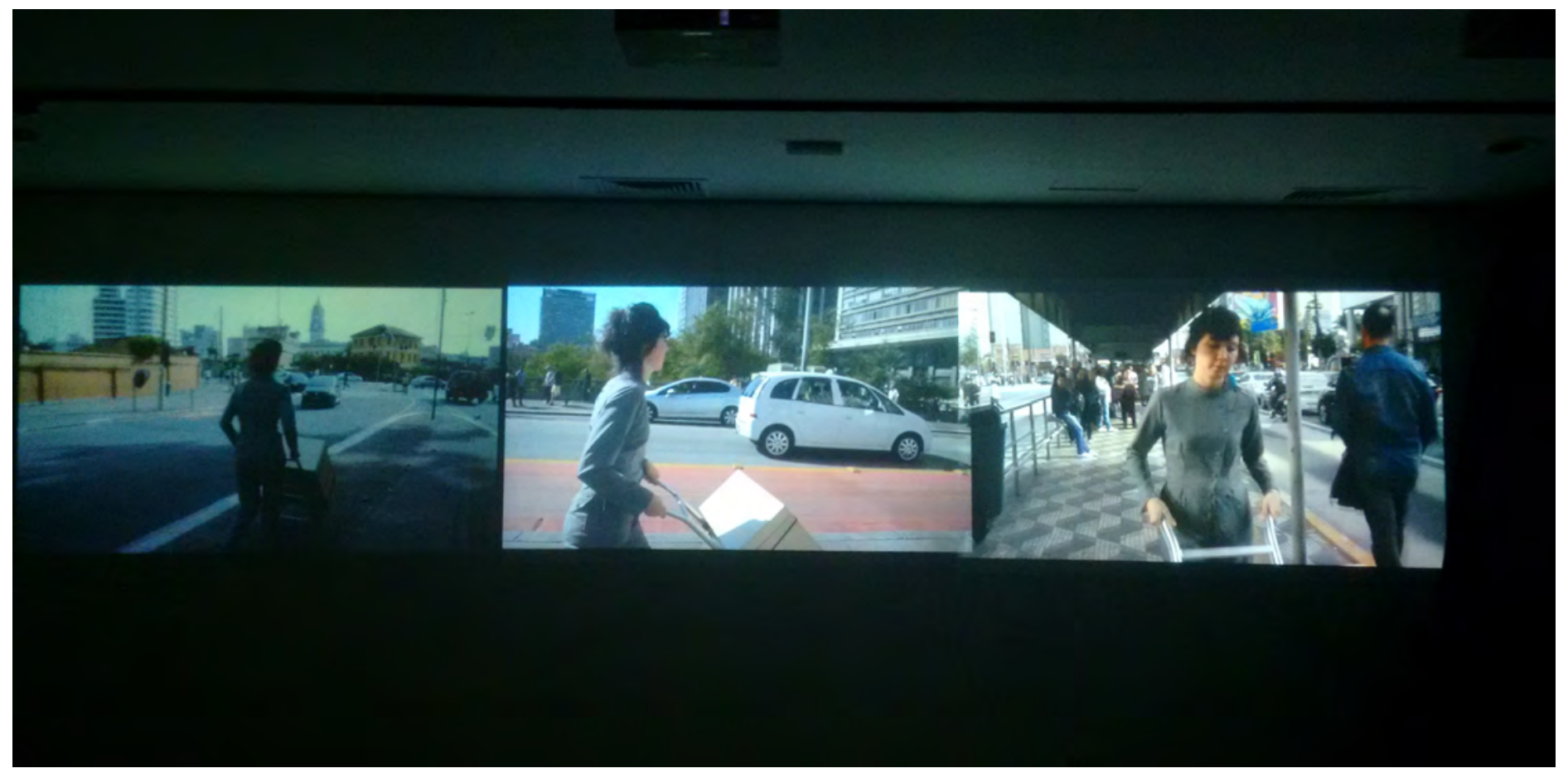


Charlatanismo, ritual, isca para uma interação social, um ruído estranho no cotidiano, mesclar-se como mais uma ambulante na cidade, acaso, uma ação dentro da vida? São proposições e questões que esse trabalho suscita. E como resposta ele perpassa todos esses itens.

Meus interesses em produzir essa ação eram diversos. Ao mesmo tempo que me propus de fato a transportar sentimentos simbolicamente, a começar pelos meus, também me interessavam todas as questões que pudessem ser levantadas sobre a ação, que já existiam como possibilidades antes mesmo de começá-la e que de fato foram suscitadas pelas pessoas, como, por exemplo, a desconfiança sobre o produto. Gerar questionamentos sobre sua autenticidade ao observar algo que é prometido era também um dos itens de interesse nesse trabalho. Hoje, diversos produtos são oferecidos a todos nós, sem passar muito por nossa reflexão. Tudo é produto, tudo é comercializado. E foi um pouco isso que tive intenção de provocar.

Gerar interações, conversas sobre histórias e desejos também faziam parte do cardápio. Outro ponto forte do conceito da obra era causar um ruído por estranhamento no cotidiano. Observar carrinhos que vendem Yakult, pipoca e outros produtos nas cidades e até mesmo na praia é comum, porém causei um ruído/ estranhamento por fazer uso da inscrição "Transporto sentimentos" ainda mais ao estender esse transporte como um serviço oferecido ao outro.
O trabalho chamou muita atenção pelo texto escrito, mas também pela parte sonora, pois as rodas do carrinho faziam muito barulho durante o movimento de caminhar, colaborando para atrair mais atenção. Talvez o fato de eu ser uma mulher a carregar um carrinho com uma caixa um tanto grande pode também ter sido um outro componente de atração para a ação.

Em todos os espaços por onde passei, a grande maioria das pessoas observou a ação e percebeu que se tratava de algo estranho. Em nenhum momento passei despercebida. Algumas contribuições ou participações no trabalho pelos espectadores foram trocas e conversas de forma lúdica, chacotas, críticas, descrédito. Outras pessoas desejavam mesmo transportar seus sentimentos.

O encontro com o outro, com o inesperado, com as possíveis reações que aconteceriam causavamme: medo, alegria, curiosidade etc. A ação seria um experimento para o outro e para mim também. Afinal, estava trabalhando minhas percepções, respostas diante do que viria, tanto física quanto emocionalmente, assim como me observar diante de questões, dúvidas, chacotas etc.

Eu estava em local público e cada vez que saía com o carrinho buscava o encontro, me expor ao outro, experienciar uma situação inusitada, observarme, observar a cidade, seus acessos, observar os 
transeuntes, suas falas, suas reações, ao mesmo tempo que minha concentração era bem intensa durante o ato de conduzir o carrinho.

Nessa obra, trabalho na esfera social em dois espaços: o da exposição (a mostra no MIS) e do urbano/público onde foi realizada a ação. Assim, opero no interstício social de que fala Bourriaud em relação às formas de operar o intercâmbio humano na arte contemporânea diferentes das zonas de comunicação que nos são impostas. Segundo o autor:

para nós, além de seu caráter comercial ou de seu valor semântico, a obra de arte representa um interstício social. O termo interstício foi usado por Karl Marx para designar comunidades de troca que escapavam ao quadro da economia capitalista, pois não obedeciam à lei do lucro: escambo, vendas com prejuízo, produções autárquicas etc. O interstício é um espaço de relações humanas que, mesmo inserido de maneira mais ou menos aberta e harmoniosa no sistema global, sugere outras possibilidades de troca além das vigentes nesse sistema. (BOURRIAUD, 2009, p. 22-23).

Com esse trabalho crio um espaço para troca, para relação social através de conversas, de possíveis "encomendas" e, embora me utilize de "tipos de comunicações" tradicionais da vida cotidiana e também muito utilizadas no comércio como o telefone, o WhatsApp e o e-mail, o serviço que ofereço é de troca. Não há taxa para sua realização, estando portanto, mesmo que dentro dos padrões formais do comércio, fora do sistema comercial financeiro. Pela sua analogia a trabalhos nos moldes comerciais, muitas pessoas me perguntaram quanto eu cobrava pelo serviço. Nesse sentido, durante meu trajeto no metrô foi necessário esconder com um plástico as informações de telefone, e-mail e os dizeres da caixa, pois ali entendiam esse trabalho com finalidades comerciais, não podendo assim circular no metrô. Fazer propaganda no metrô é proibido, a não ser que se pague por isso.

Esse trabalho também tem ligação com algumas práticas contemporâneas, como o ato de caminhar e de realizar ações em espaços fora dos espaços tradicionais de arte, como a cidade. Careri (2013, p.27), na introdução de seu livro "Walkspaces: o caminhar como prática estética", dispõe várias palavras em três colunas às quais podem ser enlaçadas à vontade para se criar, ler e realizar ações. Algumas das palavras que cita são: habitar, percorrer, caminhar, perder-se, errar, pessoas, sensações, uma cidade etc. Acrescento transportar, sentimentos, passagens de estado.

Essas palavras, segundo o autor, são ações que entraram mais recentemente para a história da arte "e que podem revelar-se um útil instrumento estético com o qual explorar e transformar os espaços nômades". (CARERI, 2013, p. 27). Nesse livro o autor, trata do caminhar de modo geral, mas foca em demonstrar que o caminhar tem produzido arquitetura e paisagem. O autor inicia sua reflexão com os caçadores do paleolítico, passando pelas práticas dadaístas, dos surrealistas, assim como 
dos situacionistas e da Land Art, dentre outros. O estudo do autor é significativo para esta tese por abordar uma genealogia do caminhar, assim como também os movimentos e artistas que fizeram esse uso.

Práticas consideradas performáticas e com o ato de caminhar em seu foco foram realizadas pelos dadaístas desde o início do século $X X$. Embora não tenham de fato realizado muitas experimentações na cidade, eles deram novas possibilidades de agir nela.

No trabalho que realizo, além de sua inserção e genealogia no campo da prática artística contemporânea ligada principalmente ao caminhar na cidade, às passagens de estados psíquicos que propõe, também pretende entender o caminhar como filosofia. Quando tive o desejo de realizar esse trabalho que teve como insight a imagem de um rapaz, um carregador de caixas de papelão a andar pela passarela da 23 de maio próxima ao MAC Ibirapuera, pensei em realizar uma ação de caminhar, carregar, talvez por remeter mais fortemente à ideia de transporte.

O caminhar foi prática filosófica realizada por muitos pensadores, artistas, poetas como forma de buscar mudanças de estados emocionais, como fonte de encontro de ideias, pensamentos, criações, como fuga, para livrar-se de depressões. Por que não para transportar sentimentos?

Pretendo dar continuidade a esse trabalho, realizando-o em outros estados e países de forma a observar como ele é recebido em diferentes culturas e costumes. Pretendo também realizar, após a captação das imagens de estados e países diferentes, uma videoinstalação com mais telas.

Para observar como em cada local esse trabalho é recebido, questionado e também transportar sentimentos de um canto do mundo a outro. 


\section{3 “Sem Título", Work in Progress (2015 - ...)}

Desculpe-me por não me apresentar como um ser forte.

Por favor, se eu for de fato um número, você poderia me chamar pelos meus números de sorte? Se sim, pode começar por estes $10984,234780,659823,2222222,487280976,4,5641890$.

Encontre-me por volta das 18:00. Estarei dentro de meu criado-mudo.

Por favor, está sol?

Você sempre acerta. Sempre fui como esses sabonetes em forma de personagens esquecidos na água, inertes no mundo.

Se não fosse you eu seria um sótão.

Compro máquina do esquecimento, a minha acabou de pifar. Entre em contato.

A partir de hoje te chamarei de you como forma de demonstrar por você meu carinho e afeto internacionalmente. Um beijão Acabou que fiquei dormindo minha vida inteira. Não foi fácil nem difícil.

As circunstâncias me fizeram ir de um absurdo a outro numa velocidade impressionante, como você já sabe.

Às vezes releio sua certidão de óbito simbólica que criei.

Fiz um puxadinho na minha vida. Beijo

Desculpe por ter ficado te observando pelo meu caleidoscópio enquanto você falava.

Existência glacial descongelando. 
Decidi sair com uma roupa insuficiente para o frio apenas para me colocar como ser causador consciente daquela sensação.

No fim acabei optando pelo polichinelo.

Hoje, entrando em uma rua, me deparei com uma ventania bem diferenciada. Aproveitei a ocasião e com meu corpo biruta escolhi o melhor ponto estratégico. Estou com os braços abertos e meu corpo está envergando. Vou ficar aqui até que ela desapareça. Te ligo. Bjos

Estou em desmanche. Volto logo.

Olá, você poderia me ajudar a levantar?

Eu sou, tu és, ele é, nós somos, vós sois, eles são. Eu era, tu eras, ele era, nós éramos, vós éreis, eles eram. Eu fui, tu foste,ele foi, nós fomos, vós fostes, eles foram. Eu seria, tu serias, ele seria, nós seríamos, vós seríeis, eles seriam.

Nunca sei o que ouvir de você.

Existir. Está bom?

Acabo de receber sua carta com a devolução do tempo que nós perdemos juntos. Não faltou nada. Você fez a divisão/devolução correta. Obrigada!

Desculpe-me.

Não sou apenas o resultado. Um beijo

Tenho tempo à venda. Terças-feiras das $14: 00$ às 14:30. Entre em contato. 
A realidade invadiu a realidade.

O que deu certo?

Reúso sentimentos.

O excesso de poeira passou a pesar sobre mim.

Você acordou respirando como ferro a vapor.

Não se preocupe. Eu guardei tuas cartas na geladeira. Beijo

Estou com medo e desta vez não é de você.

Cheguei de surpresa e te vi correndo ao redor de sua mesa por nove anos.

Acabo de ver a cor de teu fôlego.

Nossa! Você não tinha me falado de todos esses teus sintomas.

Minha presença era insignificante, mas consegui com ela tornar aquela situação constrangedora.

Lembrei-me de teu casaco com bolsos de lagos de cacos de vidro.

Seu coração batia sonoramente como um exaustor.

Eu não sei. Por favor, não me pergunte mais nada.

Passei a saltar para ver se mudava de estado. 
Você acaba de trincar minhas esperanças.

Eu, que estava tão sem treino, resolvi dar um salto e no momento estou passando pela janela do 34 andar do edifício Copan. Pelas 18:00 de amanhã vamos jantar. Ok? Um beijo

Acabo de sintetizar teus sentimentos. Te entrego à tarde.

Essas cercas foram de nossa autoria.

Estou assistindo ao trailer do que faremos hoje. Só um minuto.

Sou um ser exequível.

Eu te digo, eu gostaria de arrumar dois seres amigos novos, três do passado, um de outro mundo. Caso se interesse por alguma das categorias mencionadas, inscreva-se abaixo deixando seu nome. Haverá um pequeno processo seletivo. Até.

Você ficou de me emprestar a sua sensibilidade..

Te ligo em oito anos.

Faltou-me humanidade também. Não se atrase para o meu velório. Bjo

Não consegui deixar de ser um ser repugnante um pouco antes de você chegar.

Passei maquiagem. Exagerei no rímel para poder chorar cinematograficamente.

Olá. O olá que Ihe digo remete ao tempo passado. No presente e no futuro não posso/poderei mais Ihe dirigir a palavra. Desde que algumas coisas mudaram como minha nova vida social, meus novos atributos não me permitem mais. Um abraço do passado 
Revelei tua foto outra vez.

No fim eu era do rebanho com selo de garantia.

Eu sei quem é você. Se tiver interesse em saber mais entre em contato. Bjo

Desequilibrei. Deu medo mas acho que gostei.

Vi minha foto na sua carteira.

Estou passando o ponto. 1,65m X 0,41m. $50 \mathrm{~kg}$. Entre em contato

Passei a usar polainas como metodologia existencial.

Retirei metade de tua foto de minha carteira.

E o passado secou em um belíssimo dia de sol.

Hoje por 5" eu deixei de ser quem eu não era.

O tempo "areiou" quase tudo. Assoprando.

Resolvi trocar meus horários. Chorar das 17:00 às 17:07. Não me ligue!

Faltou-me humanidade também. Não se atrase para o meu velório. Bjo

Ainda amo

Vendendo a força que ainda tenho no braço esquerdo. Entre em contato. 
Por favor, envie-me o palimpsesto psicofisiológico de mim em ti.

Adicionei fermento no meu reflexo.

Preciso falar contigo. Mantenha-se nessa rua e direção. Quando passar por uma igreja, entre e me encontre debaixo do primeiro banco.

Atualizei minhas memórias com adobe photoshop 7.0.

Fiz um backup de ti.

No fim sai tudo pelos olhos.

Equilibrei-me em meu próprio ar.

Descolando super bonder de dentro de mim.

Ontem, subindo uma escada caí e estou caindo em câmera lenta até agora. Como estava subindo, a queda está sendo de baixo para cima. Venha comigo ! Está divertido.

Acabou que ingeri anticorpos em excesso.

Estou me esquecendo de você.

Polindo meus olhos.

Editando a vida, utilizando flashbacks, palimpsestos e play.

Passei a andar com espelhos na sola dos pés. 
Segui acompanhada por uma avalanche de areia.

Alguns venenos têm duração muito curta. Viva!

Pesquisei se havia um caso semelhante.

Em diagnóstico

Memória flex

Hoje acordei tão você!

Plagiei um terço da sua existência. Desculpe-me.

Fiquei muito feliz com nossa falta de controle e do acaso simultâneo que nos aconteceu. Adorei a submersão de nossas cabeças em nossos respectivos pratos com sopa.

Não era recomendado.

Passei a usar ratoeiras.

Acabo de imprimir sua prova de estado (P.E.10).

Sou carbono -14

Você enfatizou: CHEGA, chega, CHEGA de achar que está indo pelas bordas!!! Não existe centro nem bordas.

Dilatei minhas pupilas para ler suas cartas. 
Entrei e você estava em um ambiente sem nenhuma iluminacão, me ofereceu fósforos e a partir daí nossa conversa foi realizada assim com perguntas e respostas que duravam o acender e apagar de nossos fósforos.

Nem tudo é líquido. Versículo 18:21-200

A sua vida é muito forte em ti.

Obrigada por estar sempre presente em minhas inúmeras mortes.

Você deixa seus mil e três relógios com horas diversas, sai com óculos que alteram todas as cores, passeia com seu barco que se fixa a diversos ônibus simultaneamente para entender melhor a vida dos outros.

Achei pertinente o teu grito.

Você queria/precisava tanto se adequar que por analogia passou a usar botinhas ortopédicas na cabeça.

Você poderia negociar as memórias que tem de mim comigo? No momento posso lhe oferecer em troca: dois segundos a mais de tempo, um pano de prato que tenho de estimação ou uma uva. Aguardo.

Encontre-me às 18 horas. Estarei dentro de meu liquidificador.

Sim, sim, eu posso ser. Ora, mas o que você espera de um avatar?

Utilizei uma espécie de mata-borrão em ti.

Adoro tuas sinapses.

Consegui trocar cinco anos de vida contigo. Estranhando ainda. Escrevo para avisar que o contrato chega hoje.

Me dei alta. 
As frases anteriores fazem parte da obra "Sem Título", um work in progress, constituído por frases que se desdobram em três formatos diferentes: pela rede social Facebook, por um painel de led e uma instalação audiovisual, abordando possibilidades existenciais, modos de ser e estar no mundo, relações interpessoais, e transformações do ser, através de contrastes que ora indicam resistência ora aceitação de regras e mecanicidade ${ }^{3}$.

"Sem Título" teve início em 2015 quando comecei a escrever frases com certa frequência na rede social Facebook. Passei a compartilhar, de modo público, frases que procuram travar um diálogo com o espectador, por fazerem o uso de pronomes como você, teu e tua e por estarem abertas a todos que venham a se deparar com elas e lê-las durante o passeio pelas atualizações sociais de seus amigos do Facebook. O trabalho procura trazer pelo estranhamento reflexões sobre as relações sociais, interpessoais, modos e posturas de existência. ${ }^{4}$

3 No contexto contemporâneo saber distinguir resistência de aceitação é complicado. O poder, as esferas normativas estão tão arraigadas a vários focos de poder como as ciências, o capital, o Estado, a mídia etc interferindo em várias áreas da vida, afetiva, subjetiva, imaginário, corpo etc que já não sabemos mais se estamos de um lado ou de outro. Mesmo dessa forma podemos pensar em estratégias de escape. Esse trabalho está nessa fronteira indeterminada. PELBART aponta em Vida capital: ensaios de biopolítica (2003, p. 14 e 134) que onde existe poder sobre a vida existe resistência a esse poder (a potência da vida), potência de variação das formas de vida. Pelbart citando Guatarri acrescenta:" ao mesmo tempo que estamos "presos numa ratoeira', somos destinados às mais insólitas e exaltantes aventuras." (PELBART 2003, p.135)

40 estranhamento é causado tanto pelo conteúdo das frases como em rela- ção aos destinatários pois são frases que parecem ser direcionadas para um ser em privado mas que são exibidas de modo público. As frases embaralham conceitos de público e privado. Na internet em geral ocorre esse embaralhamento já que nesses espaços a intimidade, que era mais contida em períodos históricos anteriores, passa a ser compartilhada nas redes sociais tornando- se pública.. Para maior aprofundamento sobre os conceitos sobre público / privado consultar o estudo de Paula Sibilia em seu livro "O show do eu: a intimidade como espetáculo". A autora faz um apanhado histórico dessa diferenciação e como cada subjetividade histórica foi desenvolvida e se relaciona aos conceitos público e privado principalmente no que se refere a intimidade. O íntimo era na modernidade reservado ao privado, ligado ao quarto, aos diários íntimos. Na atualidade a existência depende da visibilidade do "eu" para o outro. Cada época produz um tipo de subjetividade a qual Foucault chama de "tecnologias do eu". 


\subsection{1“Sem Título" realizado na rede social}

\section{Facebook}

Viviane Vallades

4 de novembro de 2018 - 6 -

Editando a vida, utilizando de flashbacks, palimpsestos e play.

Viviane Vallades

6 de junho de $2018 \cdot 9$ -

Memória flex

Viviane Vallades

18 de junho de 2018 -

Deixei de dar trela para a existência

Viviane Vallades

14 de outubro de 2018 - 9 v

Segui acompanhada por uma avalanche de areia.

Viviane Vallades atualizou o próprio status

23 de março de 2017 · São Paulo, Brasi

O tempo "areiou" quase tudo. Assoprando.

Sem Título

Postagens do Facebook

$(2015-\ldots)$ work in progress
Há 3 anos

\section{Viviane Vallades}

4 de setembro de 2015 às 16:09 - São Paulo - $\mathbf{0}$

Hoje cheguei de surpresa e te vi correndo ao redor de sua mesa por nove anos.

Há 3 anos

Viviane Vallades

4 de setembro de 2015 às 09:31. São Paulo - G V

Acabo de receber sua carta com instruções sobre rejeitar o passado, presente e futuro. Obrigada. Um beijo!

Há 3 anos

Viviane Vallades

26 de agosto de 2015 às $18: 15$ - São Paulo -

Você gosta muito de grampear documentos semelhantes às quartas-feiras. 
As frases são apresentadas em meu perfil social, juntamente com outros tipos de publicações que compartilho, como fotos pessoais, links sobre artes, etc. Não criei um perfil especial para o trabalho, misturo arte e vida.

As frases são apresentadas com certa frequência e as datas ficam na ordem de realização, isto é, de postagem, mas também retomo algumas frases por compartilhamento ou nas Lembranças, recurso que o próprio Facebook disponibiliza.

Nesse espaço é comum a troca de informações, de acontecimentos da vida diária, assim como notícias falsas, verdadeiras, etc. É na área destinada a atualização de status, no espaço com a inscrição "no que você está pensando" que as frases do "Sem Título' são inseridas e enviadas para o Feed de notícias. Elas pretendem, como já comentado anteriormente, trazer questionamentos, dúvidas, ambiguidades sobre os modos de existir e sentir no cotidiano, romper através de quimeras ou de ficção científica as noções de tempo e possibilidades espaciais do corpo em algumas das frases, trazendo dúvidas de como será nossa noção de tempo e corpo, além de modos de sentir e existir num futuro próximo, misturadas ao sentir de hoje.

Como existe a mistura de minhas fotos e publicações pessoais e as frases, elas ficam na fronteira entre intimidade e ficção.
Um ponto interessante dessa prática artística no ciberespaço é a possibilidade de participação, interatividade e por escapar do controle da autoridade do sistema de arte. Diferentemente dos sistemas fundados no princípio broadcasting (rádio, televisão), isto é, uma fonte emissora para diversos receptores.

Formas low-tech da comunicação tradicional, que eram 'interativas', tais como cartas, o telefone e o telégrafo, as redes digitais de comunicação possibilitam mensagens instantâneas, e possibilitam uma janela aberta e ligada a várias pessoas simultaneamente. (SIBILIA, 2008, p.11)

Desta forma, existe a possibilidade de interação com o espectador, que pode discordar, compartilhar ou marcar como impróprias as publicações que compartilho. Embora seja limitado e reduzido o número de amigos de meu Facebook, qualquer curtida ou comentário de amigo pode aparecer e alcançar amigos de amigos, atingindo assim um público maior para o trabalho. Quase sempre as devolutivas nas interações mediadas pelo computador neste trabalho são algumas curtidas e alguns comentários. Discussões e debates acalorados não são o foco do trabalho.

As frases partem de ficções que exacerbam, exageram, ironizam algumas situações corriqueiras observadas em diálogos, como quando profiro uma frase diária, mas com noções alteradas de tempo ("Te ligo em oito anos"). Também apresento modos de se comportar e de resistência através do corpo como em “Minha presença 
era insignificante, mas consegui com ela tornar aquela situação constrangedora". Também aponto mudanças de estados psicológicos e emocionais por meio de tentativas estranhas como em: "Passei a saltar para ver se mudava de estado".

As frases pretendem ressaltar os modos de existência individual, mas relacionados aos modos/hábitos sociais e interpessoais, tratando-os ora como repetitivos, mecanizados e ficcionais diante de diversas situações cotidianas, ora como poéticos e surreais em diálogos irônicos e por vezes resistindo à mecanicidade e à conduta racional.

Algumas frases se referem a absurdos (pelo menos até o momento tecnológico, histórico e cultural em que estamos) como controlar emoções, reservando horários para chorar ou negociar o tempo através de devoluções e empréstimos. Algumas vezes as frases se ligam à ficção científica e a recursos futurísticos, como sintetizar sentimentos, ou questionam o espectador com perguntas existenciais como "O que deu certo?"

Também trabalham com os modos de sentir, de observar o mundo, o futuro marcado por possíveis tecnologias, como quando profiro a frase "Estou assistindo ao trailer do que faremos hoje. Só um minuto".

Operam também com a carga emocional, de memória afetiva em relações interpessoais ligadas principalmente à imagem fotográfica. As fotografias têm, em um de seus usos, perpetuar memórias de pessoas queridas, como algo mágico que guarda um pouco do outro em si e que podemos carregar simbolicamente de certa forma. A relação entre acontecimentos da vida entre pessoas, sentimentos e comportamentos simbólicos e ritualísticos é explorada nas imagens também, principalmente as fotográficas, como em: "Hoje me arrependo de não ter guardado uma mísera foto tua" ou em: "Retirei metade de tua foto de minha carteira".

Nas frases aparecem também descrições de microperformances ${ }^{5}$ como: "Você adquiriu o costume de andar com um alto-falante para gritar o nome de seus antepassados todos os dias às 17:08 por onde estiver".

"Você saiu com seu alto-falante proferindo, exclamando e questionando. Até onde a normalidade chegou!? Até onde a normalidade chegou!? Até onde a normalidade chegou!?"

Embora os exemplos citados tratem de relações diversas: ficção científica e vida, imagens fotográficas

5 Microperformance: Utilizei esse termo por ser uma "instrução" de uma ação efêmera que pode vir a ser realizada fisicamente na cidade, desvinculando- se assim do sistema e espaços da arte. A performance também vai nessa direção, mas achei o termo microperformance mais apropriado por ficar mais próximo do campo das micropolíticas e por ser uma ação realizada no cotidiano e que pode ser feita por qualquer um. Não é foco desse estudo discutir termos e categorias. Apenas fiz essa escolha para relacionar melhor o trabalho a uma mais próxima e possível categoria sem se restringir a ela. Já que termos como performances e microperformances são elásticos e em construção permanente.

A dimensão micropolítica das práticas no cotidiano refere-se às ações dos sujeitos que, em meio à esfera de normatividade social, podem, até mesmo sob a aparência de reprodução, transgredir ou estabelecer outros processos de organização social imbricados nas condições de existência vigentes. (CERTEAU, 2002 apud OLIVEIRA, J; CAVEDON, N. R.p. 158, 2013). 
e relações interpessoais afetivas, microperformances e micropolítica, eles têm em comum tratar, questionar as relações afetivas, interpessoais, sociais e possibilidades de existir de se comportar, de sentir.

Este trabalho pretende focar comportamentos sociais, hábitos, modos de sentir padronizados e apresentar logo a seguir, ou ainda na mesma frase, parecendo que vai seguir um rumo normal, uma distorção de sentido, e com isso traz possibilidades ou questões que embaralham, desfocam e causam estranhamento pela "Ficção" ou pela "Mentira", alterando os comportamentos "naturais". Também questiona possíveis alterações no sentir diante do capitalismo, do consumo tanto de produtos como de indivíduos e de tecnologias.

Essa temática tem pensamentos consonantes (ou próximos) em várias obras de outros autores, seja no campo das artes visuais, campo da literatura, ficção científica em estudos acadêmicos, científicos etc.

Algumas das frases que parecem absurdas podem logo se tornar cotidianas. Hoje muitas coisas corporais, mentais podem ser alteradas ou já estão em vias de se tornar realidade. A memória é um exemplo disso. Paula Sibilia, em seu livro "O show do eu: a intimidade como espetáculo" (2008), apresenta estudos e possíveis conclusões desenvolvidos por equipes das Universidades Harvard e McGill sobre as possibilidades de apagamento ou criação de memórias através de remédios.
Nossas recordações seriam plásticas e, portanto, potencialmente moldáveis - ou seja, tecnicamente manipuláveis.Pode até soar paradoxal, mas seriam justamente aquelas lembranças que se encontram mais profundamente assentadas, aquelas instaladas há muito tempo ou de forma mais intensa em nossas mentes, as que poderiam ser apagadas.(SIBILIA, 2008, p.127)

Com essa descoberta feita pela equipe das Universidades Harvard e McGill, que entende que o cérebro lida diferentemente com lembranças comuns e rotineiras das carregadas de emoção, os pesquisadores chegaram à conclusão de que as lembranças mais fortes e emotivas podem ser flexíveis sob condições emocionais. A partir dessa descoberta e do funcionamento dos mecanismos cerebrais, medicamentos que inibem os efeitos biológicos na formação dessas lembranças mais fortes, como a substancia propranolol, poderiam apagar algumas memórias. O medicamento seria usado assim que a lembrança ocorresse.

Ainda, referente aos pensamentos consonantes ao tema do meu trabalho está a ficção científica em geral e em filmes como Blade Runner, (1982) séries como Black Mirror, (2011) que trabalham com possibilidades oferecidas pelas tecnologias e que nos fazem repensar quais as diferenças entre seres humanos e robôs, e contribuem para entender, questionar o que 0 homem foi, é, e o que poderá vir a ser. Poderemos ser futuramente como robôs ou os robôs poderão ser como seres humanos, principalmente no âmbito do pensar e 
do sentir?

Em "O Humano mais humano: o que a inteligência artificial nos ensina sobre a vida." (2013) o autor Brian Christian, procura, usando o Teste de Turing, observar o que torna o ser humano mais humano e seu diferencial em relação às máquinas inteligentes (IA - Inteligência artificial). Segundo ele, o teste pode nos ensinar sobre nós mesmos. Esse Teste, inicialmente chamado de "jogo da imitação", foi criado por Alan Turing, matemático e pai da ciência da computação. No seu ensaio "Computing machinery and intelligence", realizado em 1950, o autor questionava em um primeiro momento se as máquinas poderiam pensar para logo em seguida reformular a questão para: "Há como imaginar um computador digital que faria bem o "jogo da imitação"? Pois pensar é difícil de definir. Neste teste, um entrevistador conversa com humanos e máquinas sem vê-los. Apenas a comunicação escrita acontece. Se a máquina conseguisse enganar 30 por cento dos entrevistadores, estaríamos diante de uma máquina equivalente a um ser humano ou indistinguível deste e que estaria pensando por si própria. No livro de Brian, ele relata sua experiência em participar de um prêmio chamado Prêmio Loebner, que foi criado em 1990 para aplicar o Teste de Turing. O autor se inscreveu nesse teste para ser o humano que tentaria convencer o entrevistador de que ele era um humano durante a conversa. Nesse prêmio a máquina que mais votos tiver por ter enganado mais o entrevistador ganhará o prêmio "Computador mais humano" e o humano que tiver mais pontos por ser mais humano ganhará o prêmio “Humano mais humano'. A questão do autor é como ser um humano e o que é necessário para ganhar tal título.

[...] além de seu uso como referência tecnológica, além até das questões filosóficas, biológicas e morais que suscita, o Teste de Turing, no fundo, diz respeito ao ato de comunicação. Vejo suas questões mais profundas como perguntas práticas: como fazer contato significativo uns com os outros, do modo mais significativo possível, nos limites da linguagem e do tempo? Como funciona a empatia? Por qual processo alguém surge em nossa vida e passa a significar algo para nós? Essas, a meu ver, são questões mais fundamentais do teste - as questões mais fundamentais de sermos humanos. (CHRISTIAN, 2013, p.29-30)

Podemos observar que o conceito de humano é uma questão em aberto e está cada vez mais sendo questionado. $\mathrm{E} o$ ato de comunicação é um interessante ponto a ser observado no teste. No trabalho que abordo aqui, a comunicação é realizada tanto por texto como por áudios com vozes sintéticas embaralhando esta noção entre humanos e robôs. Comentarei sobre isso mais a frente neste texto, quando trato principalmente da instalação audiovisual.

A alteração da memória pela tecnologia também é uma preocupação constante. As memórias dos seres humanos poderão ser exibidas em televisores e compartilhadas diante de um público como acontece no episódio da temporada 1 - "Toda a sua História (The Entire History of You)", de Black Mirror? 
Nesse episódio, através de um chip, as memórias dos personagens são armazenadas como um filme e podem ser acessadas diante de um público. Esse episódio expõe várias problemáticas, dentre elas a problemática ética de usar informações privadas para resolver questões nos âmbitos jurídico, afetivo etc. As memórias pessoais armazenadas são utilizadas para tomadas de posição e controle tanto das empresas privadas para contratar funcionários quanto de órgãos do governo para o aval de um embarque de um passageiro, por exemplo, como também para revelar uma traição amorosa.

As memórias também podem ser apagadas nessa série. Existe, ainda, a possibilidade da retirada do chip e assim não se lembrar de mais nada, como faz o protagonista no final desse episódio.

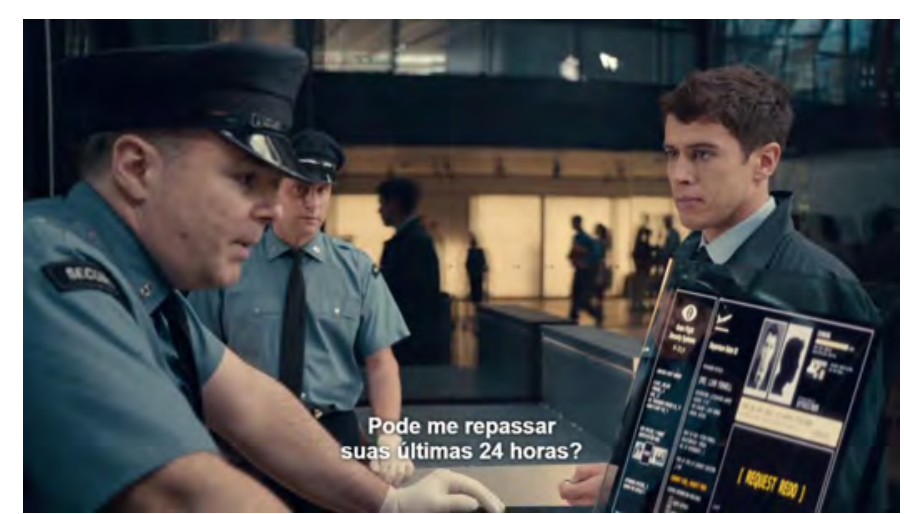

Black Mirror. Temporada 1, episódio 3

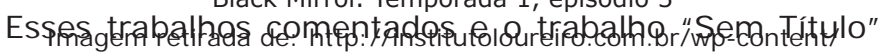
uploads/2018/02/aeroporto.png em 29/08/201811:56 pretendem, utilizando do "absurdo" ou do mimetismo, repensar possibilidades nos modos de sentir, nas noções de tempo, de ações, comportamentos etc.

Respostas, certezas, julgamentos não são o foco do trabalho. Tentar despertar questionamentos, através do estranhamento e da ludicidade dos nossos modos de vida, sentimentos, comportamentos, constituem o enredo do trabalho.

Dentro ainda dessa temática sobre as possibilidades de existir, sentir, identidade, a invenção de si e de outros, muitos estudos e trabalhos no campo das artes estão sendo feitos, questionando e trabalhando as dicotomias público/ privado. Na internet, por exemplo, inclusive na rede social Facebook, âmbito em que trabalho, essa dicotomia está totalmente se imbricando, pois o que era considerado como algo íntimo e que teria seu espaço separado do público é hoje divulgado e compartilhado publicamente. Também esse é um espaço para autorrepresentação, já que compartilhamos, principalmente através de imagens, o que gostaríamos de ser.

Muitos artistas trabalham nessa linha, questionando ou se autorrepresentando em perfis falsos, criando imagens de si com celebridades, passando por empreendedores em empresas fictícias e contando com a ideia de que se algo é amplamente difundido costuma ser verdade etc.

O artista-fotógrafo Jon Uriarte vai nessa direção em 
"CelebriMe"6 (difundido na internet em 2013). O artista, através de edições de imagens, insere a si mesmo em diversos lugares ao lado de celebridades como Angelina Jolie, Paul McCartney, Arnold Schwarzenegger etc. Manipula as imagens e as difunde em redes sociais. Ele trabalha a questão da fotografia como documento e sua distância em relação à realidade. (NUNES, 2016, p.55)

Muitos artistas abordam a dicotomia natural /artificial, e as alterações de nossas vidas por meio da tecnologia. Operam pela ficção ou no campo entre o real e a ficção através da mistura de notícias divulgadas mais recentemente juntamente com as novas possibilidades tecnológicas. Nessa linha trabalha o artista norteamericano Virgil Wong, que apresenta notícias fictícias que misturam genética, notícias recentes e novas possibilidades corporais através da tecnologia em seu site, RYK Hospital. Nesse site ele disponibiliza, por exemplo, fotos, textos e um breve documentário, “The World's First Male Pregnancy" (elaborado por ele e por Lee Mingwei,), que traz informações sobre a primeira gravidez masculina (NUNES, 2016,p 90). Os artistas, inspirando-se no modelo de documentário e seguindo os parâmetros desse gênero, vão explicando em “The World's First Male Pregnancy" como isso aconteceu e suas implicações sociais, bem como o que isso mudaria

6 http://www.jonuriarte.es/index.php?/projects/celebrime/ acesso em 04/09/2018 10:46

E no Facebook: https://www.facebook.com/jonuriarte/media_set?se$\mathrm{t}=\mathrm{a} .10152378425944883 .1073741828 .719049882 \& \mathrm{type}=1 \& \mathrm{I}=5 \mathrm{~b} 48 \overline{\mathrm{d}} 8554 \mathrm{c}$ nas relações sociais e modos de existir. "Os dois artistas são membros do 'Paperveins', descrito como um grupo multidisciplinar de artes que desenvolve trabalhos sobre o corpo humano visto através da medicina, sociedade e tecnologia7. Também muitos artistas optam por um direcionamento reflexivo e criativo sobre veracidade/ ficção nas mídias sociais, como a apresentação de personas.

Em seu livro "Mentira de artista: Arte (e tecnologia) que nos engana para repensarmos o mundo" (2016), Fábio Oliveira Nunes (artista, professor e pesquisador brasileiro) aponta a "mentira" como "método criativo", como estratégia de criação. Ele estuda e conceitua a mentira de artista através de trabalhos que se passam pelo que não são. Ele aponta que iludir no campo da arte não é uma metodologia nova, como as pinturas miméticas que enganam pela semelhança a ser o que não são. Na arte contemporânea essa estratégia metodológica é continuada com os anseios da época. Mas trata-se de uma mentira de natureza poética, uma incursão estratégica que leva em conta o contexto como um sistema em que atua. Essas mentiras de artistas são como organismos que se passam por outros. Semelhantemente ao que ocorre na natureza com os animais que fingem ser o que não são dentro de um contexto.

7 retirado de: https://www.thoughtco.com/the-worlds-first-male-pregnancy-3299603 data15-08 $201811: 39$ 
Seria o que o autor chama de mimetismo sistêmico, isto é, assim como acontece na natureza, as proposições artísticas mesclam-se com o ambiente, com o espaço, com o contexto e criam inter-relações.

O mimetismo e "a mentira" de parecer ser o que não se é são estratégias utilizadas nas proposições artísticas não apenas para um efeito de trote ou piada (embora também tenham esse teor), mas principalmente para dialogar "com mundo de aparências, expectativas e superficialidade, e, tal como a ficção científica, criam modelos capazes de repensar contextos nos quais trafegamos". (NUNES, 2016, p. 21).

As redes sociais ou a internet são espaços para esse tipo de estratégia. Nesse contexto qualquer um que tiver um aparelho e acesso à internet pode gerar informações, compartilhar verdades e mentiras, e a ficção. E é um campo fértil de ação para artistas. No âmbito da arte: "Trata-se de uma verdade sobre a mentira, porque mentira de artista é sempre uma verdade sobre todos nós e sobre o mundo que continuamente construímos".

(GALLY, 2016, p. 9)

Obras que são realizadas principalmente por meios de comunicação de massa como o rádio, a TV e principalmente redes sociais e internet nos propõem reflexões sobre a nossa crença nesses meios ou se aquilo que parece ser plausível se ajusta a um contexto esperado ou ainda sobre aquilo que é propagado como modelo para modos de existir, ser, papéis sociais etc

Os meios de comunicação e os questionamentos de sua veracidade e de seus conteúdos, bem como de seu papel modelador, têm sua tradição já, como é o caso da transmissão da história fictícia de Orson Welles ${ }^{8}$ sobre a invasão de extraterrestres noticiada pelo rádio e que causou um enorme alvoroço após sua transmissão nos Estados Unidos em 1938.

Na internet, a propagação de notícias e fotos é muito mais fácil do que nos meios de comunicação anteriores, como a TV e o rádio. E embora saibamos que podem ser apresentadas mentiras, ainda assim "a nossa crença prévia na relevância diante daquilo que se difunde a uma coletividade ainda persiste". (NUNES, 2016, p.54) Neste espaço podemos então divulgar informações falsas ou verdadeiras assim como perfis verdadeiros ou não.

Nem sempre o que postamos é verdadeiro, nem sempre é falso. Porém, para ter um perfil falso ou uma notícia falsa e que pareça real, deve-se seguir padrões miméticos da estrutura vigente; só assim ocorrem a mimetização e o "engano". O contexto é importante para a credibilidade. Fabio Nunes cita um exemplo interessante: inserir um Papai Noel numa loja de brinquedos dá mais credibilidade

\footnotetext{
8 Orson Welles fez uma transmissão via rádio utilizando recursos como efeitos sonoros, gritos, a emoção dos supostos repórteres e comentaristasda adaptação do livro de ficção científica "A guerra dos mundos", do escritor inglês Herbert George Wells, porém muitos ouvintes da rádio pegaram a narração já sendo feita e não acompanharam o início, que revelava se tratar de uma peça de radioteatro. A transmissão causou assim pânico e alvoroço.
} 
do que se exibido numa galeria de arte, pois o que conta é a expectativa do local, do contexto.

As frases que são inseridas no Facebook ou no painel de led (que tratarei mais a frente) seguem essa metodologia, pois se apropriam dos procedimentos já dados pelas estruturas de interação que o próprio Facebook oferece e dos modos dos usuários de se comunicarem. Ou seja, não interferem no formato, não criam um design específico para sua exibição, nem uma página exclusiva para isso. Trabalhar relações sociais e interpessoais nesse espaço é interessante por dialogar com uma estrutura que já se propõe a isso.

As frases são inseridas logo após ou antes de publicações como fotos pessoais, compartilhamentos de vídeo, músicas, publicações gerais e correntes de usuários de Facebook. Ficam mimetizadas e também se inserem no contexto padrão da vida cotidiana embora "virtualmente".

Após a realização deste trabalho, utilizando a rede social Facebook, passei a expandir as possibilidades de exibição e formas de interação com o espectador. Desde então, a obra possui mais dois desdobramentos: por um painel de led e uma instalação audiovisual. O teor, questionamentos e conteúdo das frases continuam os mesmos que o comentado anteriormente, porém cada formato da obra e de sua exibição procura dialogar, causar um estranhamento a seu modo, como descreverei a seguir. 


\subsection{2 "Sem Título" no formato de painel de led.}

Nesse formato as frases que compartilho no Facebook são exibidas em painel de led de $130 \mathrm{~cm}$ de largura $X 20 \mathrm{~cm}$ de altura com fonte branca, reservando uma pausa curta entre uma frase e outra. Para este formato expositivo as frases podem mudar de quantidade de apresentação para apresentação. Painéis de led se popularizaram e estão no nosso imaginário e se ligam à ideia de comércio, pois são muito utilizados no dia a dia para oferecer produtos ou serviços - principalmente para propaganda ou como painel de informação pelos metrôs, aeroportos e outros espaços públicos.

Aproprio-me de formas do cotidiano, da publicidade, utilizo o mimetismo sistêmico conforme comentado anteriormente neste texto e realizo um desvio de uso mais comum a esse elemento. ${ }^{9}$

9 Vários artistas trabalham com esse procedimento. Em relação ao uso de painéis de led, temos a artista norte-americana J enny Holzer, por exemplo.

Imagem da Exposição na Fundação Lauro Campos Exposição "A nova arte política" - que ocorreu em 2017 Sem Título, painel de led, fonte branca, $(2015-\ldots)$ work in progress Tamanho do painel de led: $130 \times 20 \mathrm{~cm}$

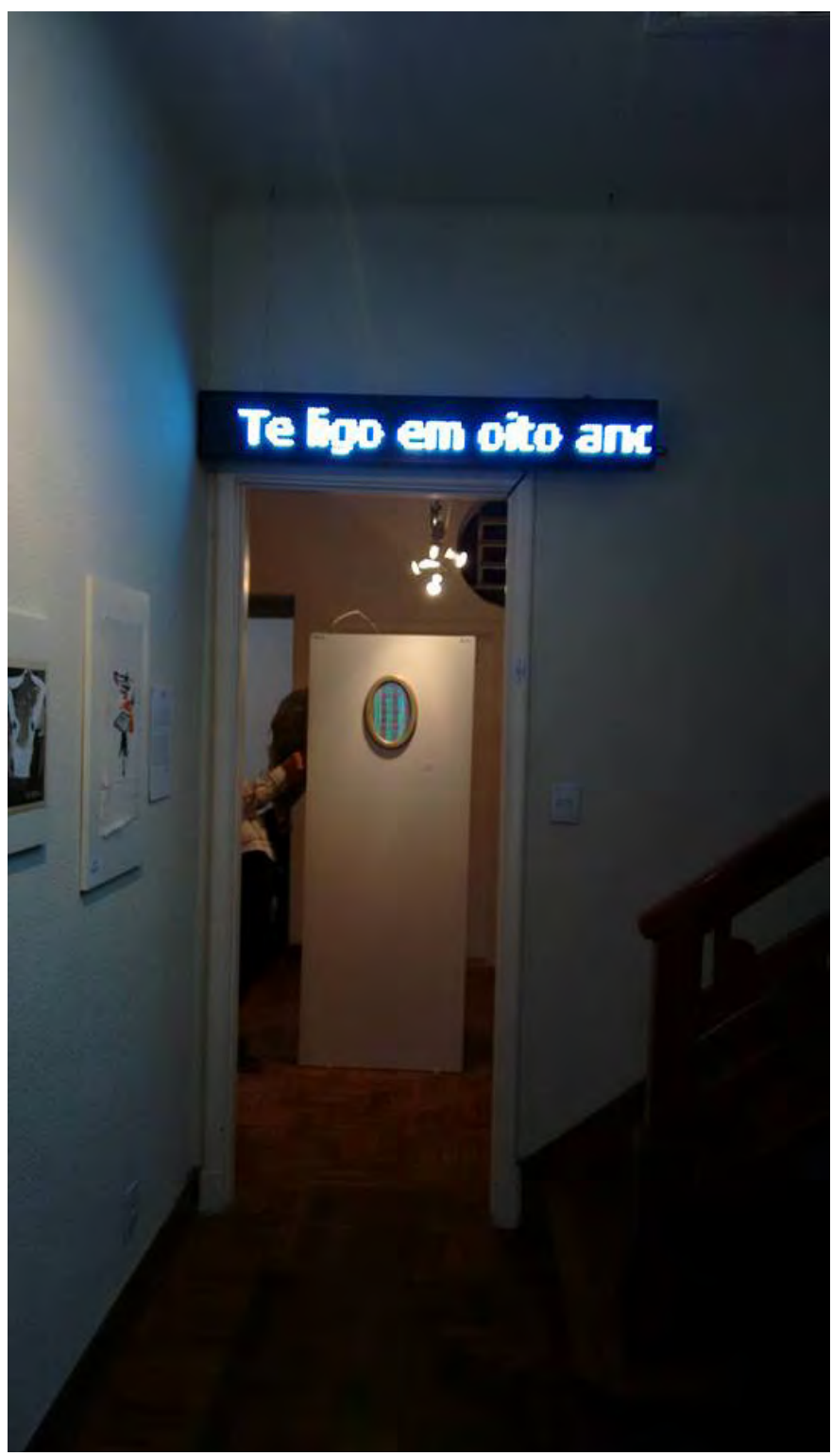


O painel de led que escolhi para a exibição das frases foi deslocado para dois espaços expositivos. Em um deles, na Fundação Lauro Campos na exposição "A nova arte política" - que ocorreu em 2017, escolhi apresentá-lo logo próximo da entrada do local expositivo para mimetizar a exibição cotidiana mais ligada a seus usos comerciais e de propaganda, que de costume apresentam o painel logo na entrada dos estabelecimentos, como chamariz para divulgação do local ou de alguma promoção. Desta forma, o painel não foi visto por muitos como obra. Muitos que estavam no espaço expositivo acharam que aquele painel pertencia à instituição; para eles, era apenas um painel informativo do local. Quando cheguei, na abertura da exposição, vários amigos, artistas e parentes perguntaram sobre minha obra, em que local ela estava, e essa conversa aconteceu debaixo do painel de led.Em outro espaço expositivo, no 49o SAC Salão de Arte Contemporânea de Piracicaba em 2017, a montagem já foi feita dentro do espaço, junto com outras obras. Ali já não havia dúvida, creio eu, que se tratava de uma obra. 


\subsection{3 "Sem Título" em instalação audiovisual}

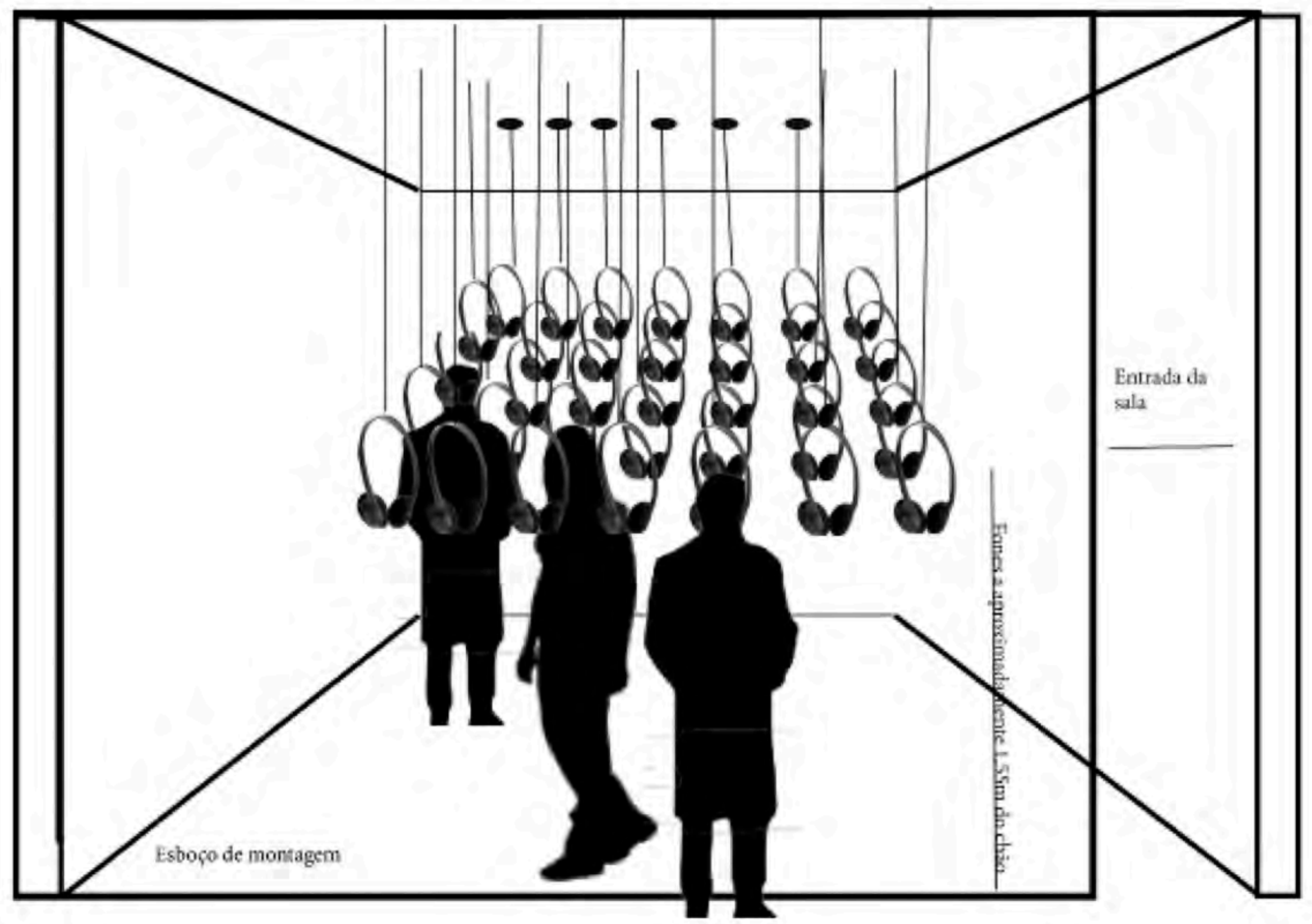

Projeto para instalação Sem Título, 2015-(work in progress), 
As frases escritas no Facebook se transformam em áudios aqui. São realizados a partir da transcrição de frases digitadas (texto) para vozes, falas mecânicas (femininas, masculinas, feitas por computador, sintetizadas). Utilizo a apropriação de vozes robóticas disponíveis na internet para a produção artística. Nesse formato instalativo os áudios são exibidos espacialmente no local expositivo, são armazenados em aparelhos de mp3 com carregador e memória e exibidos em fones de ouvido individuais. Cada frase fica em looping em um de seus fones correspondentes.

Para a instalação, as frases são selecionadas e podem mudar de quantidade, de apresentação para apresentação. O formato da instalação com fones de ouvido propõe, pela organização espacial, uma interação corporal dos espectadores, que podem ficar de frente um para o outro com certa proximidade ou não, caso se posicionem coletivamente, por exemplo. Também procuram imitar a estrutura da ocorrência de sinapses de uma forma visualmente bem mais organizada.

Utilizo o Oddcast, que é um serviço de conversão textto-speech (texto para voz). Ele oferece uma grande variedade de vozes, um avatar feminino ou um avatar masculino e aparece visualmente quando selecionamos a voz, seja de nomes masculinos ou femininos, que se encontram disponíveis. Também estão disponíveis a voz com sotaque e alguns efeitos de voz como alteração da velocidade da fala, efeitos de eco, de sussurro etc.
A conversão de texto para fala acontece pela síntese de fala, que é o processo de produção artificial da fala humana. A fala sintetizada é criada concatenando-se pedaços de falas gravadas e armazenadas em um banco de dados.
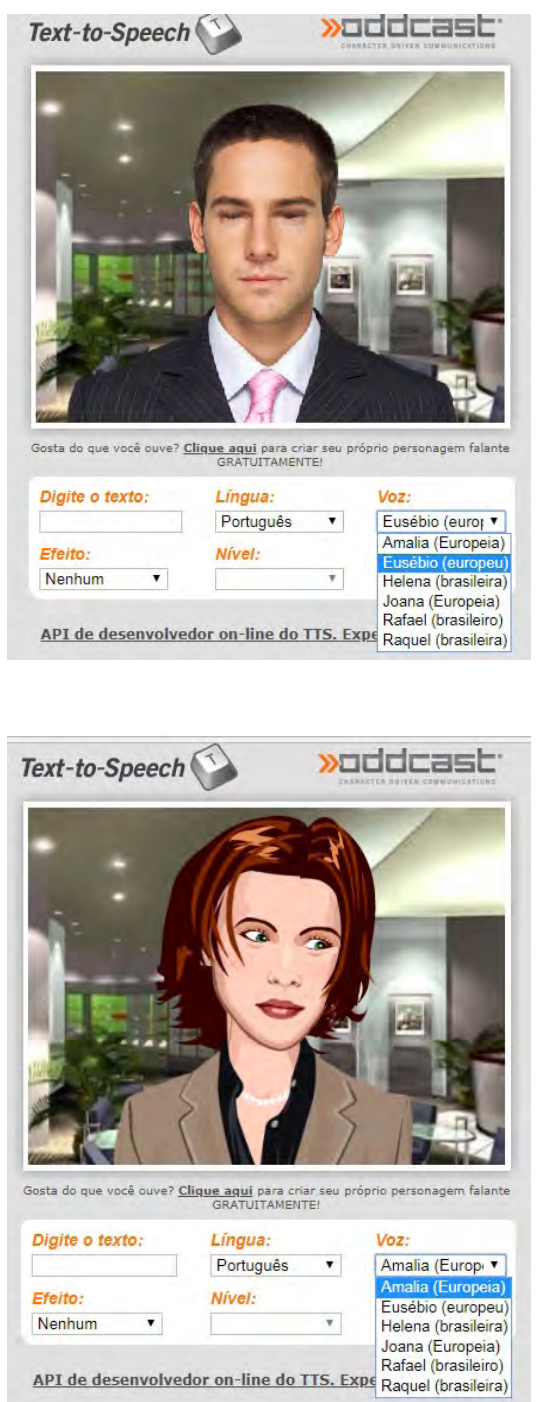
Trabalhar com frases que tratam de sentimentos, afetos, intimidade, dúvidas sobre modos de existir, sobre nossos comportamentos e hábitos utilizando vozes robóticas causa um estranhamento já que algumas das mais apontadas diferenças entre humanos e robôs até o momento seriam o pensar, o sentimento e o psiquismo.

Cada formato de exibição das obras, embora parta das mesmas frases, traz suas diferenciações e estranhamentos. As frases no Facebook, por estarem dispostas no meu perfil, ficam na fronteira entre intimidade e ficção, uma vez que não é revelado que se trata de uma obra artística. Já nos outros dois formatos existe um distanciamento do ser criador da obra. No painel de led as frases causam um estranhamento, como já comentado, pelo conteúdo e por esse painel estar mais ligado a formas comerciais e de propaganda. No formato de instalação audiovisual o estranhamento é diferenciado por apresentar falas sintetizadas tratando de sentimentos e vida. A proximidade com o espectador, pela emissão de áudios em seu ouvido, procura criar uma intimidade à sua maneira. Nos três formatos pretendi repensar o humano e nossa existência por meio de ficções. 


\section{Considerações}

Editando a vida, utilizando flashbacks, palimpsestos e play.

O corpo, meu corpo, nosso corpo, foi trabalhado e apresentado nesta pesquisa através de imagens, sons, espacialidade, que pretenderam gerar sensações visuais, auditivas etc. de modo experimental e ficcional.

Embora os trabalhos, quando contêm imagens, apresentem um único corpo (meu corpo), pretenderam ir muito além disso; pretenderam partir para o refletir o corpo coletivo em suas dores, alegrias, dúvidas, nas relações sociais, em mutações de sensibilidade, estados psicológicos, relações humano-máquina etc.

Ao mesmo tempo que trabalho meu corpo pensando nos outros corpos, procurei incorporar e dialogar com o corpo do outro. Isso fica mais evidente nos trabalhos que fiz fora de espaços expositivos, diretamente no campo social, como em Transporto sentimentos, que foi realizado pelas ruas de SP. Com esse trabalho ocorreram embates, trocas afetivas, conversas e assim ocorreu também com o trabalho Sem Título em um de seus desdobramentos: na rede social Facebook. Transitei por diversos campos (por espaços sociais, expositivos, fiz experimentações em meu corpo transformando-o, metamorfoseando-o, dissolvendo-o), que antes do início deste estudo não saberia apontar, como deixei registrado na introdução desta pesquisa. Foi no percurso, durante as cartografias, que eles foram 
tomando corpo ou corpos. Embora tenha direcionado os experimentos para o caminho "mais árido" (através principalmente de imagens e sons e não do contato ao vivo), os trabalhos pretenderam pensar as relações sociais, interpessoais e trabalhar as experiências sensoriais e o sentido háptico - o termo (háptico) "é usado para descrever o sentido do tato em sua extensão mental, desencadeada diante da experiência total de se viver e agir no espaço". (MONTAGU,1988, p.31). O sentido háptico é adquirido pela experiência de viver e traz sensações físicas imaginativas mesmo quando nos é apresentado algo visível ou aditivo, por exemplo (como imagens, vídeos, sons ou ambos). Essas sensações físicas imaginativas ocorrem através de associações de manipulações passadas. Utilizei fortemente esse sentido em alguns trabalhos, como aqueles em que uso cascas de abacaxi e de ovo em meu corpo. É para o sentido do tato principalmente que os trabalhos se direcionam e conseguem assim causar certa "aflição".

Apresentei meu corpo e por extensão nosso corpo dissolvendo, metamorfoseado, trocando ou acrescentando peles, usando máscaras e congelamentos, palavras e falas no embate diante do espelho. Pretendi percorrer partes da dimensão humana que me atravessavam. Dialoguei com alguns autores, obras que acompanham esse movimento e busca.

Essa pesquisa foi realizada em meio a instabilidades, dúvidas e angústias, assim como alegrias, descobertas, paisagens psíquicas fazendo-se e desfazendo-se. 
Ainda sou carbono 14.

Fiz um puxadinho na minha vida. Beijo

Me dei alta.

Equilibrei-me em meu próprio ar.

A realidade invadiu a realidade.

Eu sou, tu és, ele é, nós somos, vós sois, eles são. Eu era, tu eras, ele era, nós éramos, vós éreis, eles eram. Eu fui, tu foste, ele foi, nós fomos, vós fostes, eles foram. Eu seria, tu serias, ele seria, nós seríamos, vós seríeis, eles seriam.

Estou em desmanche. Volto logo 


\section{Ficções Futuras}

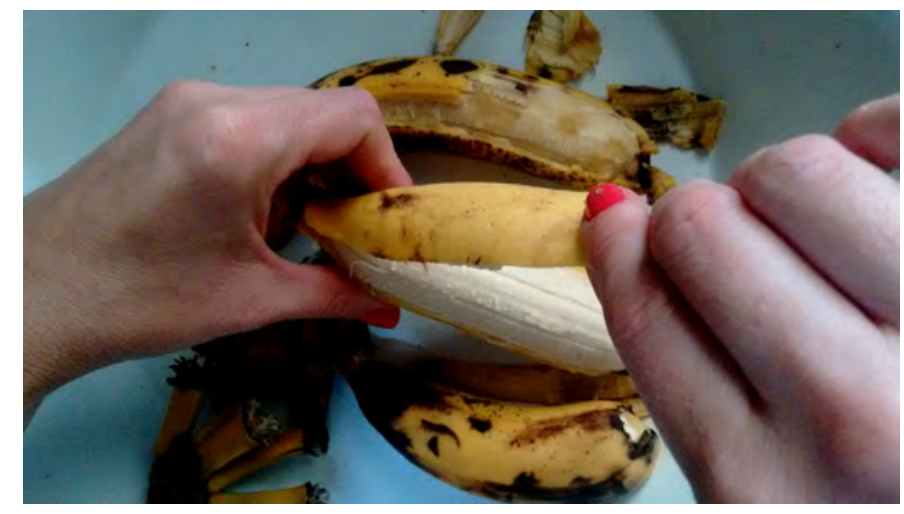

Ficar quase imóvel diante da câmera com cascas de banana mais maduras em meu corpo de forma a atrair "moscas-da-fruta", ou Drosophila melanogaster. Elas farão parte da ação juntamente com meu corpo. 


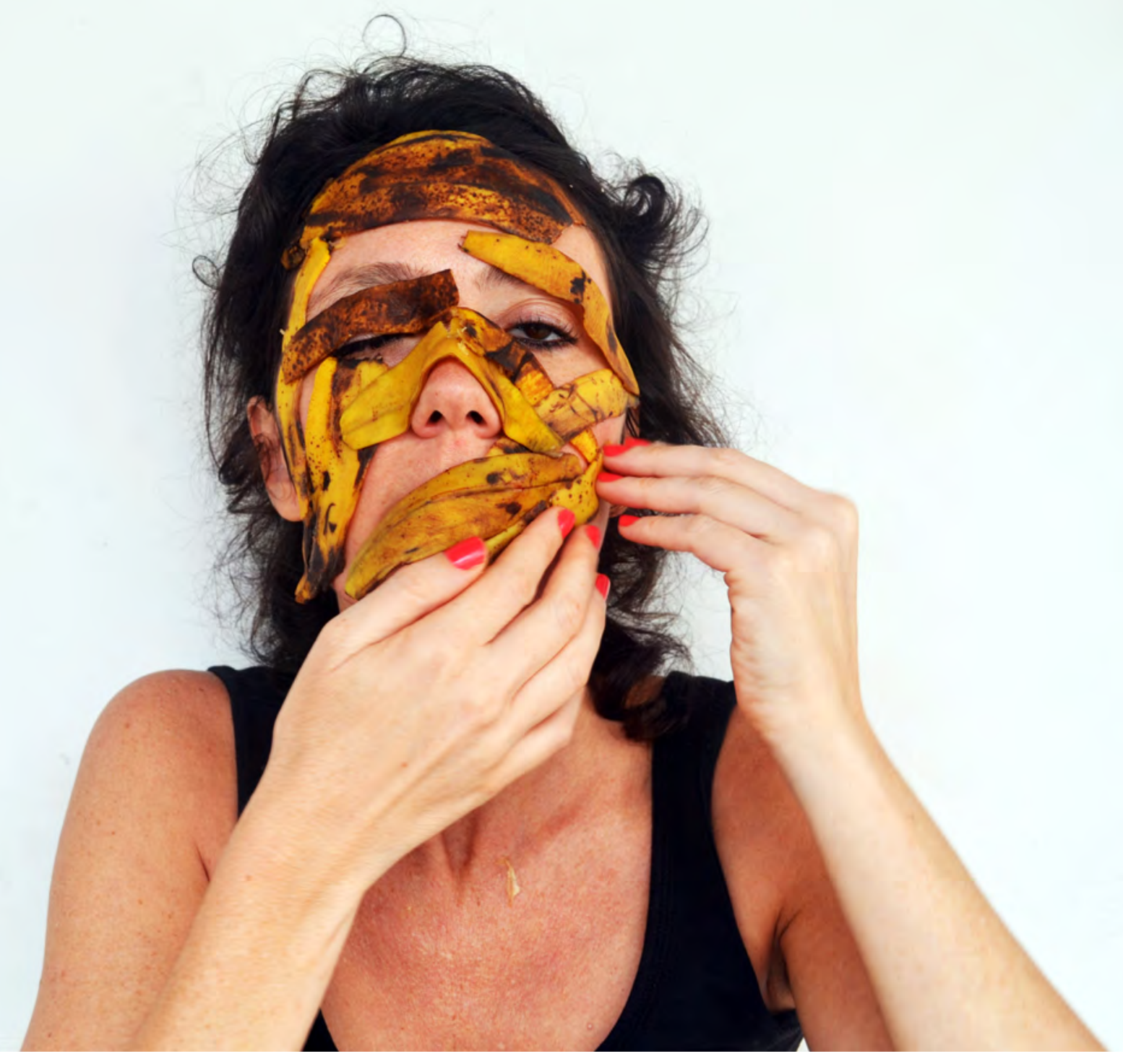




\section{Ficções Futuras}

Sala totalmente fechada e com teto.

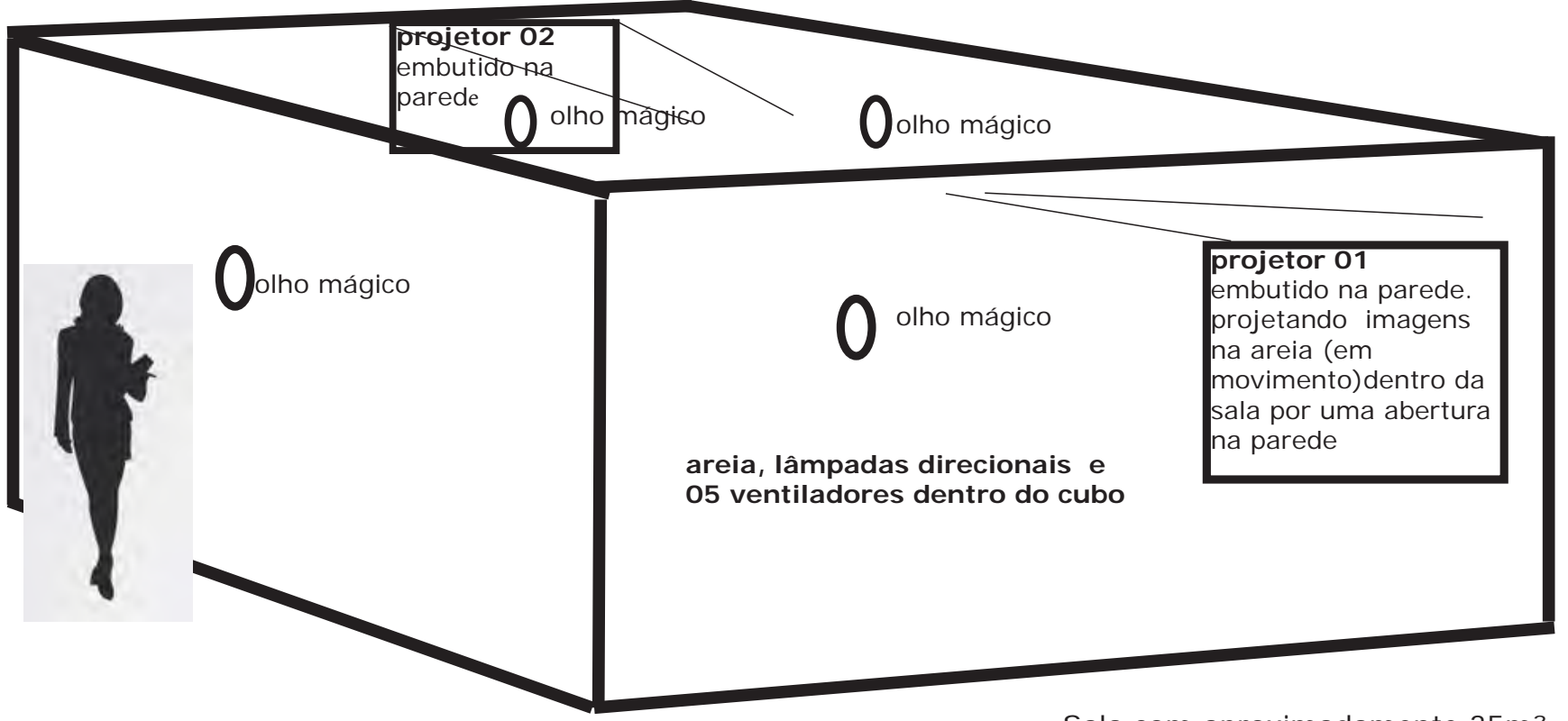

Sala com aproximadamente $35 \mathrm{~m}^{2}$.

\section{Legendas e explicações:}

04 olhos mágicos serão colocados em 04 paredes da sala. Os espectadores terão contato com a projeção na areia em movimento que ocorrerá dentro de uma sala através de 04 olhos mágicos

02 projetores serão colocados do lado de fora dessa sala fechada e apenas por uma abertura feita em duas das paredes será feita a projeção das imagens de pessoas caminhando. Os projetores principalmente suas lentes serão protegidos por uma caixa de vidro para não estragar as lentes com a areia que ficará em movimento devido aos ventiladores no espaço de dentro da sala.

05 ventiladores potentes serão utilizados para fazer a areia fina ficar em movimento no espaço interno da sala e será nela que ocorrerão as projeções de pessoas caminhando.

Serão utilizadas lâmpadas direcionais dentro da sala para melhor visualização pelos olhos mágicos. 


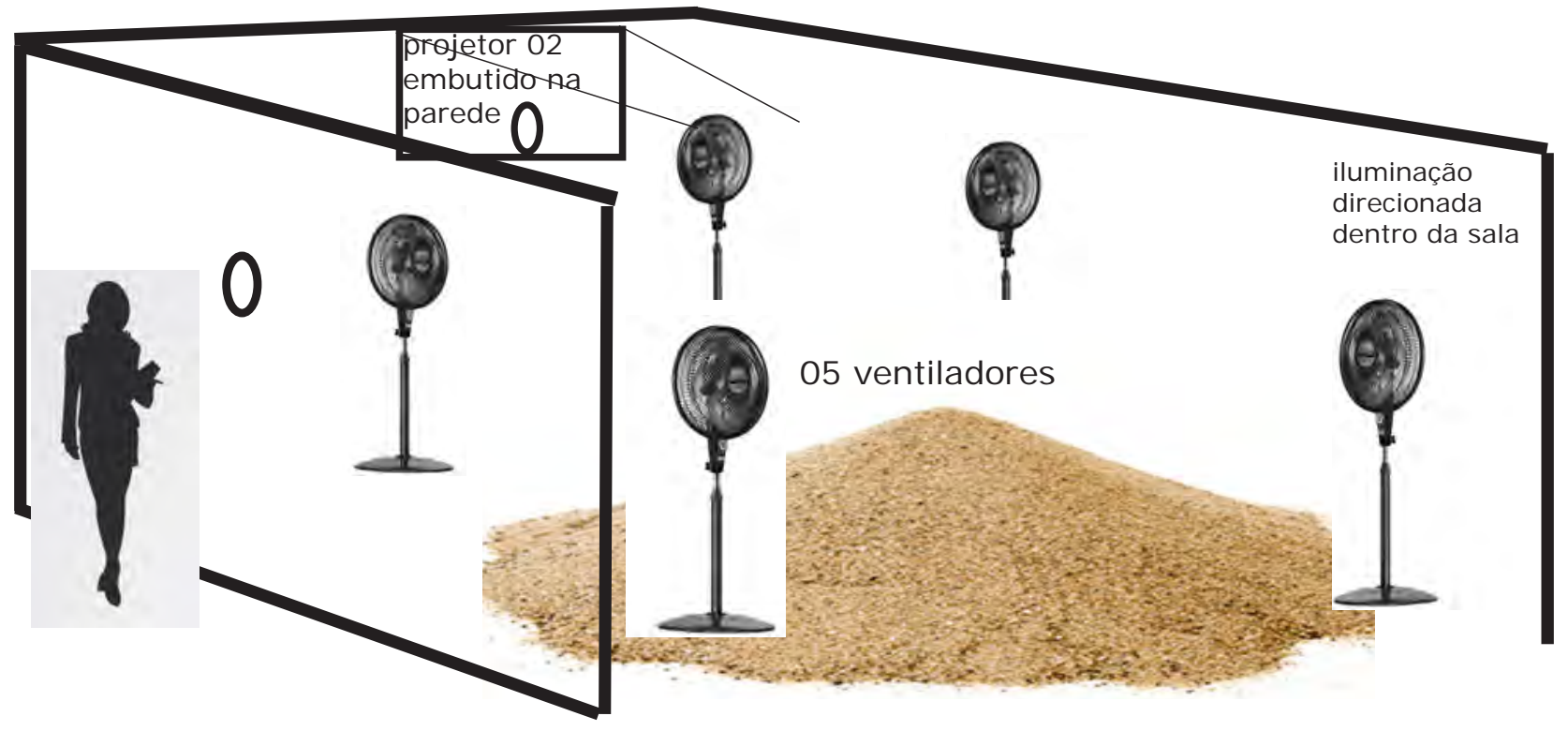

Sala totalmente fechada e com teto.

\section{Passagens}

O trabalho consiste em imagens de pessoas (silhuetas) caminhando projetadas sobre areia. A areia ficará em movimento devido ao uso de ventiladores dentro de uma sala, totalmente fechada e com teto. A observação das imagens projetadas na areia em movimento dentro da sala será feita através de olhos mágicos instalados nas 04 paredes externas desta sala, que terá aproximadamente $35 \mathrm{~m}^{2}$. Após testes de projeção, se for necessário, acrescentarei cal à areia para a nitidez da projeção.

Também farei testes de iluminação para melhor visualização pelos olhos mágicos das imagens dentro da sala. 


\section{Referências}

ANZIEU, Didier. O Eu-pele. Tradução: Zakie Yazigi Rizkallah e Rosaly Mahfuz; revisora técnica: Latife Yazigi. São Paulo: Casa do Psicólogo, 1989.

ARAÚJO, Tatiana Brandão de; BRANDÃO, Cláudia Mariza Mattos. A estética da (des)personalização nas imagens de Cindy Sherman. Revista Educação Ambiental em Ação, no 36, Ano X, Junho-Agosto de 2011. Disponível em: http://www. revistaea.org/pf.php?idartigo=1037. Acesso em nov. 2016

ASSIS, Machado de. O espelho: Esboço de uma nova teoria da alma humana. In: Contos escolhidos. São Paulo: Editora Martin Claret, 2006. (Coleção a obra prima de cada autor)

BAUMAN, Z. Vida para consumo: A transformação das pessoas em mercadoria. Tradução: Carlos Alberto Medeiros. Rio de Janeiro: Jorge Zahar Ed, 2008.

BAUMAN, Z. A Ética é possível num mundo de consumidores? Rio de Janeiro: Zahar, 2011.

BAUMAN, Z. O Mal - Estar da Pós-Modernidade. Tradução: Mauro Gama e Cláudia Martinelli Gama. Revisão Técnica: Luís Carlos Fridman. Rio de Janeiro: Zahar, 1998.

BECKETT, Samuel. Esperando Godot. Tradução: Fábio de Souza Andrade. - 1 ed. - São Paulo: Companhia das Letras, 2017.

Blade runner: O caçador de androides. Direção : Ridley Scott. 1982. DVD (117min).

BOURRIAUD, Nicolas. Estética relacional. Tradução de Denise Bottmann. São Paulo: Martins Fontes, 2009a. (Coleção Todas as Artes)

BOURRIAUD, Nicolas. Pós-Produção: como a arte reprograma o mundo contemporâneo. Tradução de Denise Bottmann. São Paulo: Martins Fontes, 2009b. (Coleção Todas as Artes) 
CANTON, Katia. Auto-retrato: espelho de artista. 2002. Universidade de São Paulo, São Paulo, 2002.

CANTON, Katia. Temas da Arte Contemporânea (Coleção - 6 volumes). São Paulo: WMF Martins Fontes, 2009, 2010.

CANTON, Katia (curadoria). Pele, alma= Skin, soul. Tradução Beth Jensen; Fotografia Rômulo Fialdini. São Paulo Centro Cultural Banco do Brasil, 2003.

CARERI, Francesco. Walkscapes: o caminhar como prática estética. Tradução: Frederico Bonaldo. São Paulo: Editora G. Gili. 2013.

Contos de Grimm. Branca de Neve e os sete anões. I lustrações de Elzbieta Gaudasinska; prefácio de Marc Soriano; tradução de Heloisa Jan- São Paulo: Companhia das Letrinhas, 1996.

COUY, Venus Brasileira. Escritas do corpo. 2006. Mestrado. Centro de Letras e Artes. Faculdade de Letras. Programa de Pós-Graduação em Ciências da Literatura. Universidade Federal do Rio de Janeiro, 2006.

CHRISTIAN, Brian. O humano mais humano: o que a inteligência artificial nos ensina sobre a vida. Trad. Laura Teixeira Motta, editora: Companhia das Letras, 2013.

CRUZ, Roberto Moreira dos S. Arte como filme, vídeo como arte. Catalogo Fluxus Black White, 2012. Oi Futuro.

DAOLIO, J. Da cultura do corpo. Campinas, SP: Papirus, 1995.

ECO, Umberto. Sobre os espelhos e outros ensaios. Tradução de Beatriz Borge. Rio de Janeiro: Nova Fronteira, 1989.

FERREIRA, Glória; Cotrim, Cecilia (orgs.). Escritos de artistas: anos 60/70. 2. ed. Rio de Janeiro : Jorge Zahar, 2009. FOUCAULT, M. Vigiar e punir: história da violência nas prisões. Petrópolis: Vozes, 1987.

GALLY, Miguel. Prefácio de Mentira de artista; arte (e tecnologia) que nos engana para repensarmos o mundo.( Nunes, Fábio Oliveira). São Paulo: Cosmogonias Elétricas, 2016. 
GOFFMAN, Erving. A representação do eu na vida cotidiana. Tradução de Maria Célia Santos Raposo, 13ed. Petrópolis: Editora vozes, 2005.

GOLDBERG, Roselee. A arte da performance: do futurismo ao presente. São Paulo: Martins Fontes, 2006.

GULLAR, Ferreira. Na vertigem do dia; prefácio de Alcides Villaça. - 1 ed. - São Paulo: Companhia das Letras, 2017

HALL, Stuart. A identidade cultural na pós - modernidade: tradução Tomaz Tadeu da Silva, Guaracira Lopes Louro - 11 ed. Rio de Janeiro: DP\&A, 2006.

KAFKA, Franz. A metamorfose. Tradução e posfácio de Modesto Carone. São Paulo: Companhia das letras, 2012.

KAFKA, Franz. O artista da fome. Virtual Books Online M\&M Editores Ltda. 2002/2003 Disponível em: http://coral. ufsm.br/gpforma/2senafe/PDF/b15.pdf

LACAN, J. (1998). O estádio do espelho como formador da função do eu. In: J. Lacan, Escritos. (V. Ribeiro, trad.; pp. 96-103). Rio de Janeiro: Zahar. (Original publicado em 1966).

LAPOUJADE, David. O corpo que não aguenta mais, in Nietsche e Deleuze: Que pode o corpo, LINS, Daniel e GADELHA, Sylvio (orgs.). Rio de Janeiro, Relume Dumará : Fortaleza, CE: Secretaria da Cultura e Desporto, 2002. (coleção Outros Diálogos : 8)

LAURENTIZ, Paulo. A holarquia do pensamento artístico. Campinas, SP: Ed. Unicamp, 1991.

LE BRETON, David. A sociologia do corpo. Tradução de Sonia M.S. Fuhrmann, 2o. Ed. Petrópolis, RJ: Vozes, 2007. Adeus ao Corpo: Antropologia e Sociedade. Campinas, SP: Papirus, 2003.

As paixões ordinárias: antropologia das emoções. Tradução de Luís Alberto Salton Peretti. Petrópolis, RJ : Editora Vozes, 2009.

Petrópolis, RJ : Vozes, 2013. 
LIPOVETSKY, G. A era do vazio: Ensaio sobre o individualismo contemporâneo. Tradução: Miguel Serras Pereira e Ana Luísa Faria. Lisboa Relógio D'Agua, 1983.

Os Tempos hipermodernos. Tradução: Mário Vilela. 4ed. São Paulo: Editora Barcarolla, 2004

MACHADO, Arlindo (org.). Made in Brasil. Três décadas do vídeo brasileiro. São Paulo: Itaú Cultural, 2003.

MARQUETTI, Flávia Regina; FUNARI, Pedro Paulo A (Orgs). Sobre a pele. I magens e metamorfoses do corpo. São Paulo Intermeios FAPESP Campinas UNICAMP 2015

MELIM, Regina. Performance nas artes visuais. Rio de Janeiro: J orge Zahar, 2008.

MELLO, Christine. Extremidades do Vídeo. São Paulo: Editora Senac, 2008.

MELVI LLE, Herman. Bartleby, o escrivão. Uma história de Wall Street. São Paulo: Cosac \& Naif, 2005.

MIRANDA, José Bragança de. Corpo e imagem. São Paulo: Annablume, 2011.

MONTAGU, Ashley. Tocar: o significado humano da pele. Tradução: Maria Sílvia Mourão Netto. 7 ed. São Paulo: Summus, 1988.

Nunes, Fábio Oliveira. Mentira de artista; arte (e tecnologia) que nos engana para repensarmos o mundo. Prefácio de Miguel Gally. São Paulo: Cosmogonias Elétricas, 2016.

OLIVEIRA, J; CAVEDON, N. Micropolíticas das práticas cotidianas: etnografando uma organização circense. In: Rev. Adm. Empres. Vol. 53 no. 2, p. 156-168. São Paulo mar./abr. 2013. (http://dx.doi.org/10.1590/S003475902013000200004 )

Ostrower, Fayga. Acasos e criação artística. 1a ed. - Campinas, sp: Editora da Unicamp, 2013.

PELBART, Peter Pál. Vida capital: ensaios de biopolítica. São Paulo: Iluminuras, 2003.

Biopolítica. Sala Preta, São Paulo, USP, v. 7, n. 1, p. 57-66, 2007 . https://doi.org/10.11606/

issn.2238-3867.v7i0p57-66 
A vertigem por um fio : políticas da subjetividade contemporânea. São Paulo: Iluminuras/FAPESP,

2000 .

REY, Sandra. Da prática à teoria: três instâncias metodológicas sobre a pesquisa em poéticas visuais. Porto Arte, v. 7, n. 13, nov. 1996, p. 81-95.

ROLNIK, Suely. Cartografia sentimental: transformações contemporâneas do desejo. São Paulo: Estação Liberdade, 1989.

ROSA, J oão Guimarães. O espelho. In: Primeiras estórias. Rio de Janeiro: Nova Fronteira. 1988 (pp.65-72)

RUSH, Michael. Novas mídias na arte contemporânea. Tradução Cássia Maria Nasser; revisão da tradução Marylene Pinto Michael. São Paulo: Martins Fontes, 2006.

SAFATLE, Vladimir. O que vem após a imagem de si? Tropico/ Do cumenta. Disponível em: http://www.revistatropico. com.br/tropico/html/print/2793.htm. Acesso em nov 2016.

SALLES, Cecília Almeida. Gesto inacabado: processo de criação artística. 4.ed. São Paulo : Annablume : FAPESP, 2009.

Redes de Criação: construção da obra de arte. Vinhedo : Horizonte, 2006.

SANT'ANNA, Denise Bernuzzi de (ORG.). Políticas do corpo: elementos para uma história das práticas corporais. Tradução: Mariluce Moura. São Paulo: Estação Liberdade, 1995.

SANTAELLA, Lucia. Cultura e artes do pós-humano: Da cultura das mídias à cibercultura. 3ed. São Paulo: Paulus, 2008

SIBILIA, Paula. O show do eu: a intimidade como espetáculo: Rio de Janeiro: Nova Fronteira, 2008.

Sibilia, Paula. O homem pós-orgânico : corpo, subjetividade e tecnologias digitais. 3.ed. Rio de Janeiro, RJ: Relume Dumará, 2006. 
SILVA, Sergio Gomes da. As modificações corporais na sociedade contemporânea. Cad. Psicanál. CPRJ, Rio de Janeiro, v.33, n.25, p. 239-257, 2011. (disponível em: http://www.cprj.com.br/imagenscadernos/caderno25_pdf/20_ CP_25_AS_MODIFICACOES_CORPORAIS_NA_SOCIEDADE.pdf)

The Entire History of You. In: Black Mirror [série de televisão, série 1 ; episódio 3]. Produtores: Charlie Brooker e Annabel J ones. Endemol UK, 2011.

STILES, Kristine; SELZ, Peter (eds.). Theories and Documents of Contemporary Art: a sourcebook of artist's writings. Berkeley: University of California Press, 1996.

VILLAÇA, Nízia. Em nome do corpo. Rio de Janeiro : Rocco, 1998.

ZAMPERETTI, Maristani Polidori . ARTE E MÁSCARAS - O SABER DE SI PRODUZINDO CONHECIMENTO. ANPEDSUL 2008. VII Seminário de Pesquisa em Educação da Região Sul. Pesquisa em educação e Inserção Social. 22, 23,24 e 25 de junho UNIVALI - Itajaí - SC. 


\section{Apêndice}

Em anexo a esse estudo segue um DVD contendo os trabalhos em vídeo.

OBRAS:

Autorretrato com duração e sons variáveis I, 2011 (registro da videoinstalação)

Autorretrato com duração e sons variáveis II , 2012 (registro da videoinstalação)

Autorretrato com duração e sons variáveis I I I , 2012 (registro da videoinstalação)

Autorretrato com duração e sons variáveis IV, 2014 (registro da videoinstalação)

Autorretrato com duração e sons variáveis V, 2019 (registro da videoinstalação)

Sem Título, vídeo, ano 2015, duração: 04'25", Câmera: Mercedes Espirito

Autorretrato com chave de fenda, vídeo, ano 2016, duração: 03'00". Câmera: Mercedes Espirito

Sem Título, vídeo, ano 2016, duração: 02'00". Câmera: Regina Vallades, iluminação: Mercedes Espirito

Sem Título Versão 1: vídeo, Duração 01'39", ano 2016, Câmera: Mercedes Espirito

Sem Título Versão 2: vídeo, Duração 03'40", ano 2016, Câmera: Mercedes Espirito

Sem Título, vídeo, Duração: 05'33", ano 2015.

Transporto sentimentos. Duração: 19'56", ano 2016, câmera: Kadu Rossi.

Projeto em vídeo para instalação Sem Título, (2015- work in progress) 